Izadora De La Volpe Mattiello

\title{
Avaliação de corantes para a detecção da viabilidade do fitoplâncton marinho
}

\author{
Dissertação apresentada ao Instituto \\ Oceanográfico da Universidade de São Paulo, \\ como parte dos requisitos para obtenção do \\ título de Mestre em Ciências, Programa de \\ Oceanografia, área de Oceanografia Biológica. \\ Orientador: Prof. Dr. Rubens Mendes Lopes
}

São Paulo 


\section{Universidade de São Paulo \\ Instituto Oceanográfico}

Avaliação de corantes para a detecção da viabilidade do fitoplâncton
marinho

Izadora De La Volpe Mattiello

Dissertação apresentada ao Instituto Oceanográfico da Universidade de São Paulo, como parte dos requisitos para obtenção do título de Mestre em Ciências, área de

Oceanografia Biológica.

Julgada em

Orientador: Prof. Dr. Rubens Mendes Lopes

Conceito

$\operatorname{Prof(a).} \operatorname{Dr}(\mathrm{a})$.

Conceito

$\operatorname{Prof(a).} \operatorname{Dr}(\mathrm{a})$.

Conceito 


\section{Agradecimentos}

Primeiramente, agradeço à Capes e à FAPESP pelas bolsas concedidas, as quais permitiram que eu desenvolvesse o meu projeto de mestrado com apoio financeiro.

Agradeço à USP, ao Instituto Oceanográfico e seus funcionários, em especial a Secretaria de Pós Graduação, pela formação, infraestrutura e auxílio em todos os momentos do meu mestrado. Ana Paula muito obrigada por toda ajuda.

Ao meu orientador Rubens Mendes Lopes, muito obrigada por ter confiado no meu trabalho desde o início, por ter enriquecido minha formação com experiências tecnológicas e inovadoras, e por sua compreensão com os meus home office devido à distância da minha casa até a USP.

À Camila Andrade, o meu muito obrigado por todo o auxílio com as cepas do banco de microalgas do IO, às diversas vezes que emprestou material autoclavado, cuidou da autoclave e repicou as minhas algas, além das conversas de distração!

Às técnicas Cidinha e Ruth que lavaram todo o material utilizado neste trabalho, muito obrigada!

À Marta Stephan que me deu todas as dicas para iniciar meu projeto, o material que eu deveria comprar, usar, como fazer o desenho experimental e como cuidar das microalgas. Obrigada também pela amizade e pela maior encomenda de cupcakes que eu já recebi!

Agradeço à Flávia Saldanha-Côrrea e Mayza Pompeu pela carinhosa atenção que deram tanto para o meu projeto como para minha vida pessoal. A confiança e a amizade de vocês foram essenciais nesta fase. Mulheres pesquisadoras que me inspiraram a trabalhar!

Meu agradecimento em especial ao professor Alexsander Turra, que não me deixou desistir de nada, à sua confiança, palavras de conforto e apoio. Sempre disposto a ajudar e pronto para as inúmeras conversas no corredor e na Didi. Obrigada por tudo!

Ao professor Marcelo Carreño e sua equipe, em especial Ariel Ades e Leandro Matiolli, por toda a experiência aprendida na Poli-USP. Foi muito enriquecedor.

Agradeço Damian Matuszewski por programar a função de extração de quadros no MatLab e o software de padronização de luz do microscópio. Sem isso, não iria conseguir inovar o método de registro das células. Muito obrigada também pela amizade, ideias para o projeto, paciência e inúmeras conversas sobre a Europa que descontraíram meus dias.

À Regina Kawai e Ricardo Gobbi da Evonik, por cederem gentilmente a amostra de Peraclean Ocean, importada da Alemanha.

À empresa incubada no Cietec, Brasil Ozônio, em especial à Taís Cecchi, por todo o suporte nos experimentos de ozônio, além do interesse no projeto e simpatia.

Ao professor Louis Peperzak, do NIOZ-Texel, por ter me recebido tão bem em seu laboratório, pela confiança e incansável gentileza e simpatia. Foi uma experiência muito desafiadora e que enriqueceu minha formação acadêmica.

À professora Vivian H. Pellizari e sua equipe, principalmente Rosa e Diego, que emprestaram gentilmente o microscópio de fluorescência Olympus BX51. 
Ao meu querido "estagiário" Henrique Batistuzzo por toda ajuda com os experimentos, ideias, dúvidas que me ajudaram a pensar, melhorias do projeto e à amizade. Foi muito gostoso poder ensinar o pouco que eu sei para um aluno tão inteligente e dedicado. Boa sorte, você tem futuro!

Não posso deixar de agradecer às pessoas que ajudaram indiretamente nesse período, aliás, um pesquisador não vive somente de pesquisa. Então:

Agradeço à amizade dos ex e atuais integrantes do LAPS que conheci. Realmente o Rubens conseguiu reunir pessoas muito especiais! Dani, Si e Maiá: obrigada por ficarem até de noite no lab e me acompanharem no metrô, a agradável presença de vocês lá me ajudou a ter gás para fazer os experimentos...e, claro, dar muitas risadas.

Cat e Nairuta, muito obrigada pela amizade e ajuda com relatórios, ideias de experimentos e sanar dúvidas científicas. Vocês foram minhas co-orientadoras!

Cássia e Newtão, a boa energia e bondade de vocês foram essenciais para mim na fase final do mestrado. Vocês são um exemplo de casal de biólogos pesquisadores da nova geração! Maria passa na frente!

Obrigada turma de mestrado 2012, pessoal do laboratório do prof. Mário, do corredor do Bentos e do café da Didi, por terem feito a convivência no IO ser muito gostosa.

Agradeço à amizade da Camila e Carolina Ortulan, e das agregadas da casa Maria Carolina Hernandez e Caroline Ykuta, fiéis confidentes. Aquele apartamento tem histórias!

Obrigada aos meus amigos campineiros e do $\mathrm{ABC}$ paulista, que é preciso uma dissertação de mais de cem páginas para descrever cada um deles. $\mathrm{O}$ apoio de vocês foi sensacional. E a cara de ponto de interrogação de vocês quando eu começava a falar do meu projeto era impagável! Mas a imensa atenção e a importância que deram para o meu mestrado foi umas das maiores provas de amizade. Obrigada a todos.

Agradeço à minha segunda família, Wanderléia, Toninho, Yorhan, Rachel e Yan, por todo o carinho, apoio e ajuda prestada neste período. Só vocês conseguiam levantar meu astral de tanto orgulho de mim. Amo vocês.

Meu mais que especial obrigado à minha família que me criou, deu apoio incondicional e base para uma formação que eu chegasse até aqui. Mãe, pai, Rodolfo e Dodó: amo vocês. Vocês são essenciais na minha vida e fizeram muita falta por estarem longe...Mas que nem diz meu irmão (ou Darwin?): os mais fortes sobrevivem!

E por último, mas não menos especial, ao meu grande amor, companheiro e melhor amigo, Lorhan. Só você sabe o que passamos, por isso, muito obrigada por acreditar tanto em mim, por seu orgulho do meu trabalho, a sua imensa paciência e ter me apoiado incondicionalmente. Você não tem noção de como você foi importante nesta fase da minha vida que eu tanto sonhei, de ser mestre. Esta dissertação é totalmente dedicada a VOCÊ meu amor...te amo. E que se inicie a nova fase! 


\section{Sumário}

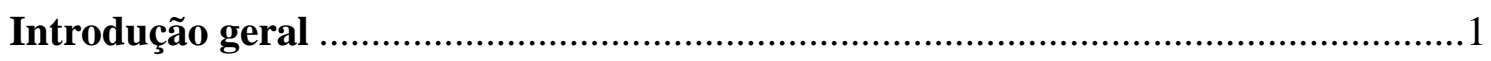

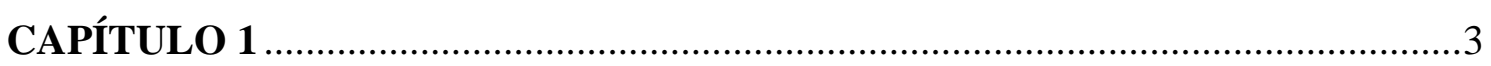

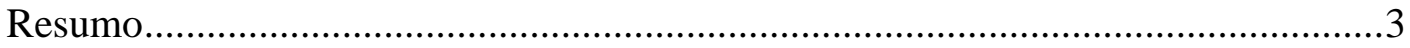

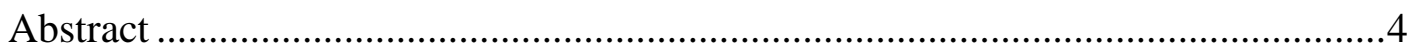

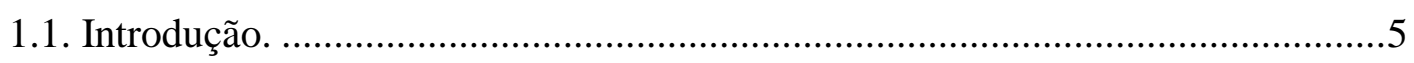

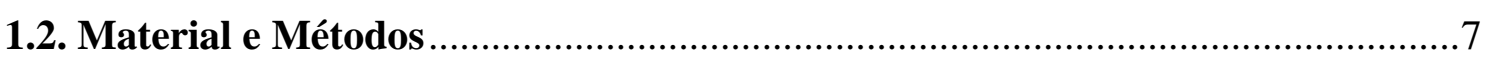

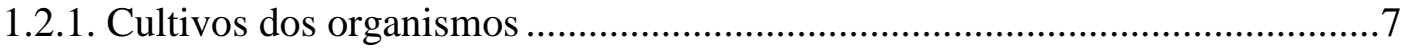

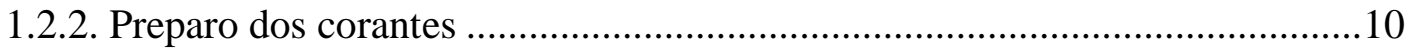

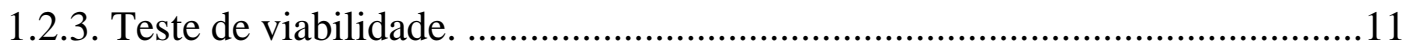

1.2.4. Técnicas de observação e registro de células ...............................................15

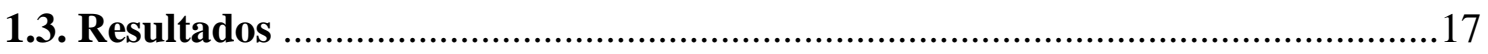

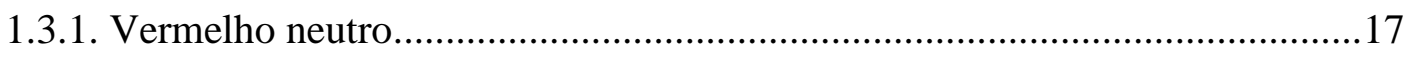

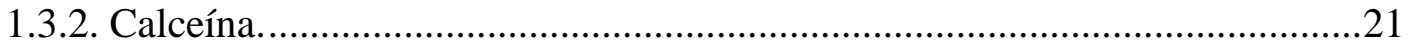

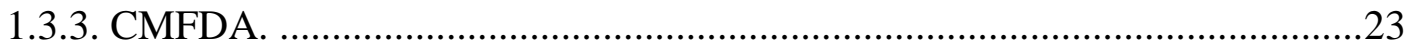

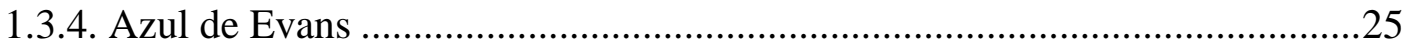

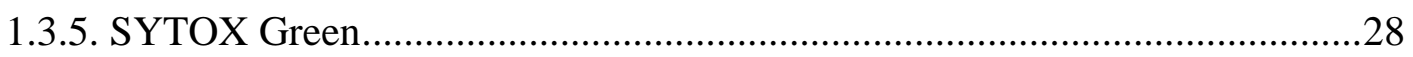

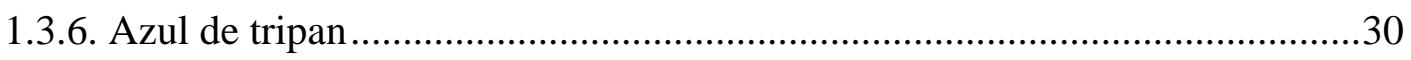

1.3.7. Combinação vermelho neutro + azul de Evans............................................ 30

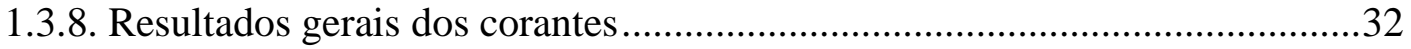

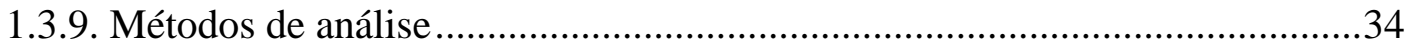

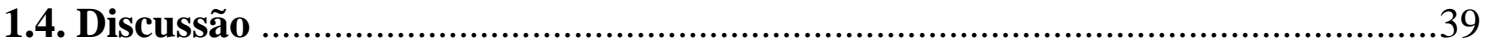

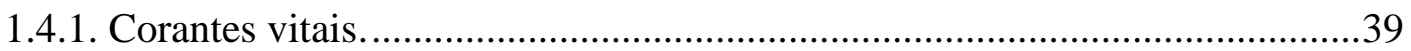

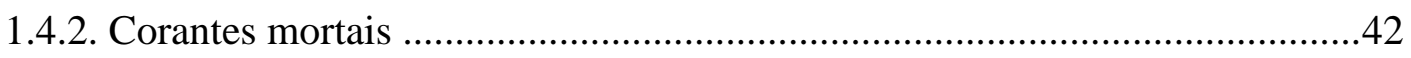

1.4.3. Microscopia X filmagem X FlowCAM ..................................................43

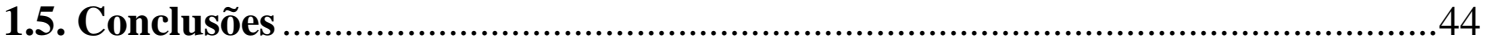

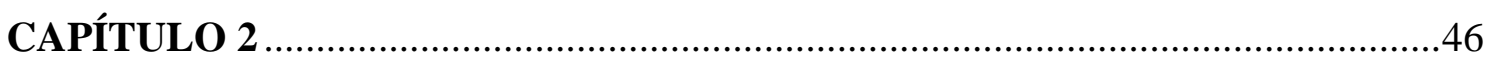

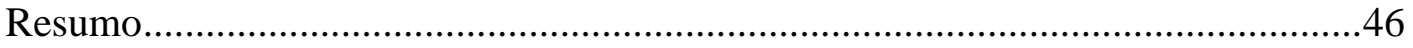

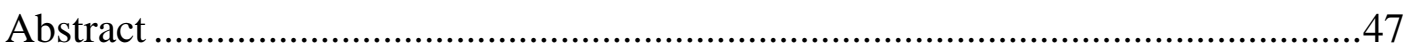

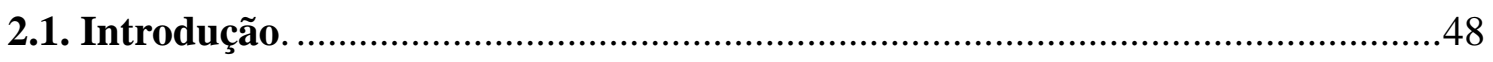

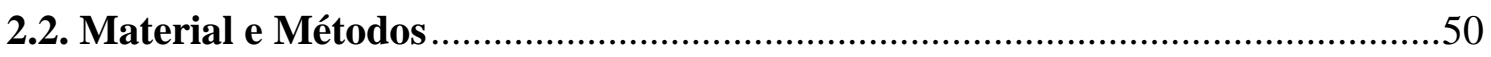

2.2.1. Espécies de fitoplâncton............................................................................50 


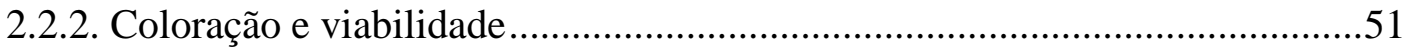

2.2.3. Radiação ultravioleta.................................................................................

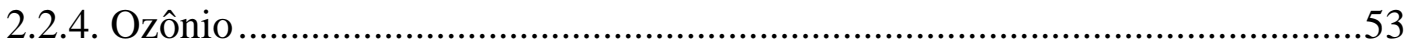

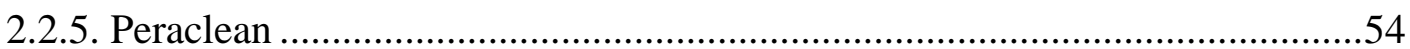

2.2.6. Teste de monitoramento da viabilidade ......................................................54

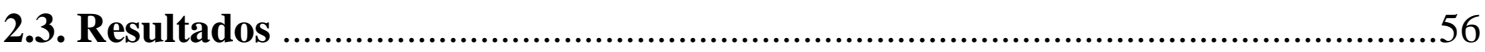

2.3.1. Radiação ultravioleta (UV) ....................................................................56

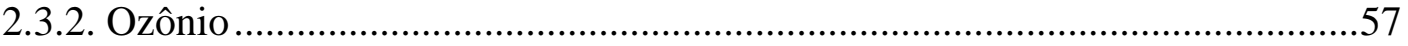

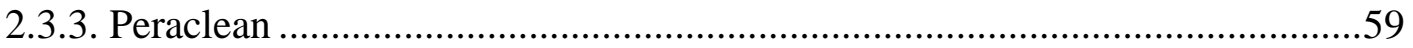

2.3.4. Teste de monitoramento da viabilidade ......................................................59

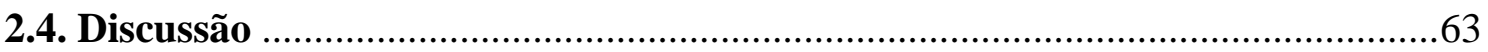

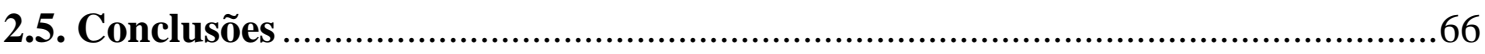

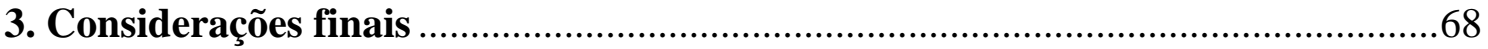

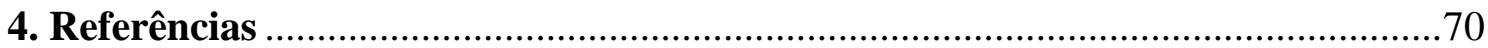




\section{Índice de figuras}

\section{CAPÍTULO 1}

Figura 1.1. Câmara de germinação onde foram mantidas as culturas utilizadas, BMA\&K/IOUSP

Figura 1.2. Fluxo laminar com o UV ligado para a esterilização do material utilizado no preparo dos cultivos, BMA\&K/IOUSP.....

Figura 1.3. Placa multipoços de acrílico com amostras de fitoplâncton coradas com o azul de Evans.

Figura 1.4. a) Software CaptureFlux 6.0.5 (Paul Glagla) utilizado para a filmagem das células; b) Exemplo de um quadro extraído

Figura 1.5. Imagens de Chattonella sp. em diversas condições: a) Ação do vermelho neutro após 20 minutos, as células estão lisadas, com pouco conteúdo celular; b) Ação do vermelho neutro após 30 minutos: além da lise das células, há formação de cristais (seta); c) Resultado da ação de $\mathrm{HCl} 10 \%$, as células ficaram menores, arredondadas, mas não apresentaram aspecto de lise celular; d) Resultado da adição de água destilada na amostra, nenhuma célula rompida

Figura 1.6. Comparação entre os tempos de coloração do vermelho neutro e a média das porcentagens de células coradas entre as diferentes espécies testadas.

Figura 1.7. Relação entre as médias (preto) observadas de células vivas coradas por vermelho neutro e a porcentagem esperada por espécie testada. Em vermelho, estão representadas as medianas de cada conjunto de réplicas. As barras verticais representam o desvio padrão. $\mathrm{O} *$ indica que o desvio padrão ultrapassou a área do gráfico representada

Figura 1.8. Padrão de coloração usado para distinguir células coradas e não coradas com o corante vermelho neutro. Na linha a) T. gracilis, até a $4^{\mathrm{a}}$ imagem: células coradas; b) T. pseudonana, até a $3^{\text {a }}$ imagem: células coradas; c) P. gracile e d) A. tamiyavanichii, até $4^{\mathrm{a}}$ imagem foram consideradas coradas 
Figura 1.9. Relação entre as médias (preto) observadas de células vivas coradas por calceína e a porcentagem esperada por espécie testada. Em vermelho, estão representadas as medianas de cada conjunto de réplicas. As barras verticais representam o desvio padrão. Não há dados de contagem para a espécie T. pseudonana no tratamento de $100 \%$ de células vivas, devido à dificuldade de visualização e distinção para a contagem. $\mathrm{O} *$ indica que o desvio padrão ultrapassou a área do gráfico representada..22

Figura 1.10. Imagens das células coradas pela calceína (vivas $-1^{\mathrm{a}}$ coluna, fundo preto) e não coradas (mortas - $2^{\text {a }}$ coluna). Em a) Chattonella sp. $(30-40 \mu \mathrm{m})$; b) $T$. pseudonana $(7-11 \mu \mathrm{m})$; c) P. gracile $(40-50 \mu \mathrm{m})$ e d) A. tamiyavanichi $(30-40 \mu \mathrm{m})$

Figura 1.11. Relação entre as médias (preto) observadas de células vivas coradas por CMFDA e a porcentagem esperada por espécie testada. Em vermelho, estão representadas as medianas de cada conjunto de réplicas. As barras verticais representam o desvio padrão. $\mathrm{O} *$ indica que o desvio padrão ultrapassou a área do gráfico representada .24

Figura 1.12. Imagens das células coradas pelo CMFDA (vivas $-1^{a}$ coluna, fundo preto) e não coradas (mortas - $2^{\mathrm{a}}$ coluna). Em a) Chattonella sp.; b) T. gracilis; c) T.pseudonana; d) P. gracile e, e) A. tamiyavanichii.... .25

Figura 1.13. Comparação entre os tempos de coloração do corante mortal azul de Evans e a média das porcentagens de células coradas entre as diferentes espécies testadas .....26

Figura 1.14. Relação entre as médias (preto) observadas de células mortas coradas por azul de Evans e a porcentagem esperada por espécie testada. Em vermelho, estão representadas as medianas de cada conjunto de réplicas. As barras verticais representam o desvio padrão. .27

Figura 1.15. Padrão de coloração usado para distinguir células coradas e não coradas com o corante azul de Evans. Em a) Chattonella sp e b) T. pseudonana, até a $3^{\text {a }}$ imagem: células coradas; c) P. gracile, até $4^{\text {a }}$ imagem foram consideradas coradas, apesar da $4^{\text {a }}$ gerar muita dúvida, dependendo do padrão de luz do computador; d) $A$. tamiyavanichii, até $3^{\mathrm{a}}$ imagem: células coradas, na $4^{\mathrm{a}}$ : teca corada, mas não foi considerada célula morta, excluímos da contagem .28 
Figura 1.16. Relação entre as médias (preto) observadas de células mortas coradas por SYTOX Green e a porcentagem esperada por espécie testada. Em vermelho, estão representadas as medianas de cada conjunto de réplicas. As barras verticais representam o desvio padrão. Não foram feitos testes com os dinoflagelados no tratamento de $0 \%$ de células mortas, devido ao pouco volume do corante disponível para o experimento .....29

Figura 1.17. Imagens das células coradas pelo SYTOX Green (mortas $-1^{\mathrm{a}}$ coluna, fundo preto) e não coradas (vivas - $2^{\mathrm{a}}$ coluna). Em a) Chattonella sp.; b) T. gracilis; c) T.pseudonana; d) P. gracile e, e) A. tamiyavanichii....

Figura 1.18. Análise em câmara Nageotte de uma alíquota contendo ambos os corantes, adicionados a $1 \mathrm{~mL}$ de cultura de $P$. gracile. Observa-se grande quantidade de detritos corados

Figura 1.19. Porcentagem do número de células coradas e não coradas nos diversos tratamentos: VN: vermelho neutro individual em cultura na fase exponencial; EB: azul de Evans individual em cultura na fase exponencial; VN + EB: combinação entre vermelho neutro e azul de Evans em cultura na fase exponencial; 50\%: combinação entre vermelho neutro e azul de Evans em 50\% do volume de cultura na fase exponencial e $50 \%$ do volume da cultura morta por aquecimento. Do lado esquerdo, resultados com a espécie $T$. pseudonana, e do direito, a espécie $P$. gracile 32

Figura 1.20. Resumo por corante das relações entre as médias da porcentagem de células coradas observadas pelo esperado de cada espécie. Corantes vitais: vermelho neutro, calceína e CMFDA, \% células vivas. Corantes mortais: azul de Evans e SYTOX Green, \% células mortas. Nesta figura não há a indicação da variação de cada média, pois já foi indicado individualmente nas seções anteriores 33

Figura 1.21. Correlação entre a porcentagem observada de células coradas pelo vermelho neutro e o esperado, das contagens feitas pelos métodos de observação direta (quadrado) e captura de imagem por filmagem (círculo)

Figura 1.22. Correlação entre a porcentagem observada de células coradas pelo azul de Evans e o esperado, das contagens feitas pelos métodos de observação direta (quadrado) e captura de imagem por filmagem (círculo) .35 
Figura 1.23. Correlação entre a porcentagem observada de células coradas pelo vermelho neutro e o esperado, das contagens feitas pelos métodos de observação direta (quadrado) e captura de imagem pela FlowCAM (círculo) .36

Figura 1.24. Correlação entre a porcentagem observada de células coradas pelo vermelho neutro e o esperado, das contagens feitas pelos métodos de observação direta (quadrado) e captura de imagem pela FlowCAM (círculo) .37

Figura 1.25. Imagens capturadas pela FlowCAM da espécie T. gracilis com o vermelho neutro. Note que há células que ficaram sem foco, mas mesmo assim é possível identificar a coloração .37

Figura 1.26. Imagens capturadas pela FlowCAM da espécie T. pseudonana com o vermelho neutro. Note que há vinhetas com mais de uma célula. Neste caso, foi feita uma biblioteca somente para estas imagens, para dobrar a contagem. Os detritos foram descartados da contagem .38

Figura 1.27. Imagens capturadas pela FlowCAM da espécie $P$. gracile com o azul de Evans. Note a presença de detritos, os quais foram descartados da contagem. .38

Figura 1.28. Imagens capturadas pela FlowCAM da espécie Chattonella sp. com o azul de Evans. Note que há tanto células intactas como células que sofreram lise celular que foram coradas pelo azul de Evans. Ambos os casos foram contados como células coradas. Os detritos foram descartados da contagem

\section{CAPÍTULO 2}

Figura 2.1. Em A, o fluxo laminar com a lâmpada UV-C ligada; em B, modo e distância de como as amostras ficaram expostas à radiação UV.

Figura 2.2. Placa multipoços de acrílico, onde as amostras tratadas foram alocadas para a posterior adição dos corantes vermelho e azul de Evans. Cada poço continha $1 \mathrm{~mL}$ de amostra por réplica

Figura 2.3. Em A, o equipamento da Brasil Ozônio que transforma $\mathrm{O}_{2}$ em $\mathrm{O}_{3}$ (Fonte da imagem: www.brasilozonio.com.br); em B, aplicação do ozônio na amostra através da pedra difusora na mangueira.

Figura 2.4. Porcentagem da média das células mortas (não coradas pelo VN - vermelho neutro ou coradas pelo EB - azul de Evans) após o tratamento com UV para cada 
espécie. As barras verticais indicam o erro padrão. SD indica "Sem dados", no caso dos corantes que não funcionam em determinadas espécies. Chatto: Chattonella sp., Alex: Alexandrium tamiyavanichii, Tetra: Tetraselmis gracilis, Pro: Prorocentrum gracile, Tha: Thalassiosira pseudonana

Figura 2.5. Porcentagem da média das células mortas (não coradas pelo VN - vermelho neutro ou coradas pelo EB - azul de Evans) após o tratamento de ozônio de cada espécie. A barra vertical inica o erro padrão. SD indica "Sem dados", no caso dos corantes que não funcionam em determinadas espécies. Alex: Alexandrium tamiyavanichii, Tetra: Tetraselmis gracilis, Pro: Prorocentrum gracile

Figura 2.6. Concentrações médias de células viáveis e inviáveis em cada tratamento (controle, semi-fechado, e semi-aberto) de Prorocentrum gracile, durante os 25 dias do experimento. As células viáveis foram coradas pelo vermelho neutro

Figura 2.7. Concentrações médias de células viáveis e inviáveis em cada tratamento (controle, semi-fechado, e semi-aberto) de Thalassiosira pseudonana, durante os dias do experimento. As células viáveis foram coradas pelo vermelho neutro 


\section{Índice de tabelas}

\section{CAPÍtULO 1}

Tabela 1.1. Informações dos corantes biológicos não fluorescentes utilizado

Tabela 1.2. Informações dos corantes biológicos fluorescentes utilizados

Tabela 1.3. Tratamentos testados com proporções de volumes de alíquotas com células vivas e mortas, em relação a $1 \mathrm{~mL}$ de amostra. Na tabela, as porcentagens estão relacionadas às células vivas, na fase exponencial de crescimento. 13

Tabela 1.4. Volumes e tempos de coloração utilizados para cada corante nos testes da eficácia de coloração. $\mathrm{O}$ volume do corante é referente para $1 \mathrm{~mL}$ de amostra

Tabela 1.5. Resumo das características de cada técnica de observação e registro das células de fitoplâncton usadas neste trabalho

\section{CAPÍTULO 2}

Tabela 2.1. Densidades médias dos cultivos utilizados no experimento de tratamento com UV

Tabela 2.2. Densidades médias dos cultivos utilizados no experimento de tratamento com ozônio

Tabela 2.3. Média da porcentagem de mortalidade das células após o tratamento com UV, detectada pelos corantes vermelho neutro e azul de Evans; e média do número de células contabilizadas em cada contagem. Os controles são com o tratamento de aumento de temperatura.

Tabela 2.4. Média da porcentagem de mortalidade das células após o tratamento com ozônio, detectada pelos corantes vermelho neutro e azul de Evans; e média do número de células contabilizadas em cada contagem. Os controles são com o tratamento de aumento de temperatura. .58 


\section{Introdução geral}

As espécies do fitoplâncton são componentes importantes dos ecossistemas marinhos, pois formam a base das teias alimentares pelágicas e desempenham um papel central nos ciclos biogeoquímicos dos oceanos (Falkowski, 2012). Além disso, várias espécies de fitoplâncton são indicadores hidrológicos, pois produzem toxinas que podem causar efeitos nocivos em cascata sobre as comunidades biológicas, com consequências negativas para a atividade econômica (Knap et al., 2002) e a saúde pública (Matsuoka \& Fukyo, 2000).

Por serem de tamanho reduzido (geralmente $<200 \mu \mathrm{m}$ ) e de mobilidade limitada, estas espécies são afetadas rapidamente por distúrbios ambientais, tanto de eventos naturais como de atividades humanas, como, por exemplo, contaminação por descarga de efluentes, derramamento de óleo e mudanças climáticas (Thyssen et al., 2008; González et al., 2009; Bickel et al., 2011). Portanto, impactos que afetam a viabilidade destes organismos e, consequentemente, a produtividade primária, podem acarretar na desestruturação do equilíbrio trófico, na baixa produtividade e prejuízos em atividades econômicas, como a pesca, a aquicultura e o turismo.

Geralmente um organismo é considerado viável quando está vivo e tem a capacidade de crescer e se reproduzir, e não viável quando está morto. Para alguns autores, nem sempre estar vivo indica estar viável, por isso, utilizam o termo vitalidade como a manifestação de vida e viabilidade capacidade de crescimento (Peperzak \& Brussaard, 2011). Neste estudo, com o intuito de simplificar, foi utilizado o termo viável para os organismos vivos, independente da capacidade de crescimento e reprodução.

A viabilidade pode ser detectada por diversas abordagens analíticas, como o estudo do movimento, respiração celular, batimentos cardíacos, estado nutricional, crescimento e reprodução, entre outras atividades metabólicas (Carney, 2011). Para o fitoplâncton, a viabilidade é detectada por processos metabólicos e mudanças morfológicas (Onji et al., 2000; Peperzak \& Brussaard, 2011).

Estudos sobre viabilidade do fitoplâncton ganharam um impulso adicional em anos recentes devido à necessidade do monitoramento biológico da água de lastro de navios (Steinberg et al., 2011). A introdução de espécies exóticas por água de lastro pode contribuir para a alteração da estrutura da comunidade planctônica da região 
invadida, devido à competição por recursos limitantes, eventualmente levando à exclusão ou diminuição da abundância de espécies nativas (Silva \& Souza, 2004; Zvyagintsev, 2009; Butrón et al., 2011). O fitoplâncton também é capaz de formar cistos de resistência (Gregg \& Hallegraeff, 2007), o que possibilita o transporte por água de lastro tanto de células ativas como de células de resistência, mesmo sob condições ambientais adversas nos tanques dos navios.

Vários tipos de corantes, devido à facilidade de seus métodos, têm sido usados com sucesso em análises microscópicas para avaliação da viabilidade ou mortalidade dos organismos planctônicos (Agustí \& Sánchez, 2002; Peperzak \& Brussaard, 2011; Steinberg et al., 2011), inclusive em estudos sobre efeitos de impactos. A viabilidade celular pode ser detectada por corantes devido às mudanças morfológicas, fisiológicas e na permeabilidade da membrana da célula (Coder, 1997). Estas mudanças são resultantes de condições ambientais desfavoráveis, como a falta de nutrientes ou de luz, exposição a contaminantes, herbivoria e infecções virais, situações que levam à morte celular (Veldhuis et al., 2001; Brussaard et al., 2001; Garvey et al., 2007).

Este trabalho abordou técnicas para detecção da viabilidade do fitoplâncton marinho, através de testes com corantes vitais e mortais, visando o fornecimento de subsídios para novos métodos de detecção dos organismos planctônicos a serem aplicados no monitoramento ambiental e na gestão da água de lastro de navios.

A dissertação foi dividida em dois capítulos redigidos na forma de manuscrito, sendo o primeiro intitulado "Uso de métodos de coloração para a identificação da viabilidade do fitoplâncton marinho", o qual aborda testes com diferentes corantes, em uso individual e combinado, em relação à concentração, tempo de coloração e à aplicabilidade universal para detecção da viabilidade em diferentes espécies de fitoplâncton. O capítulo também aborda a eficiência de diferentes métodos de observação e registro das células coradas e não coradas.

O segundo capítulo, intitulado "Avaliação da eficácia de corantes para a detecção da viabilidade do fitoplâncton após tratamento da água de lastro", avalia a eficácia da coloração vital e mortal nas células de fitoplâncton após submetidas a processos de tratamento da água de lastro dos navios, incluindo a radiação ultravioleta, o ozônio e o germicida Peraclean, a fim de avaliar se a coloração é uma técnica aplicável para a validação da eficiência do tratamento. 
CAPÍTULO 1

\title{
Uso de métodos de coloração para a identificação da viabilidade do fitoplâncton marinho
}

\begin{abstract}
RESUMO
O fitoplâncton é sensível às perturbações ambientais e identificar a viabilidade destes organismos é importante para o monitoramento aquático. $\mathrm{O}$ termo viabilidade tem sido usado neste contexto para determinar basicamente se o organismo está vivo ou morto. $\mathrm{O}$ uso de corantes vitais e mortais tem sido uma das técnicas aplicadas neste tipo de análise, mas ainda não se conhece a potencialidade de alguns corantes que se apliquem a espécies de fitoplâncton. Neste trabalho, foram utilizadas espécies de diferentes grupos taxonômicos mantidas em cultivo, as quais foram submetidas a uma série de corantes vitais e mortais com o objetivo de detectar a viabilidade do fitoplâcton marinho. Dentre os corantes testados, o vermelho neutro, azul de Evans e o fluorescente CMFDA tiveram os melhores resultados (observado $\mathrm{x}$ esperado) em testes com diferentes porcentagens de células vivas e mortas. A combinação entre o corante vital vermelho neutro e o mortal azul de Evans não foi efetiva para análise simultânea. Alexandrium tamiyavanichii foi a espécie que teve menor afinidade com os corantes. Também foram comparados diferentes métodos de observação e registro de células coradas e não coradas, provando que é possível substituir a observação direta da microscopia pela filmagem no microscópio ou pela FlowCAM. A vantagem do uso destes métodos é que além de serem mais rápidos, é possível salvar as imagens capturadas e não é necessário fazer a análise instantaneamente. O método da filmagem é vantajoso, pois é fácil de ser desenvolvido em qualquer laboratório.
\end{abstract}

Palavras-chave: corantes vitais, contagem de fitoplâncton, vermelho neutro, azul de Evans 


\begin{abstract}
Phytoplankton cells are sensitive to environmental perturbations and, therefore, identifying their viability is important for aquatic monitoring. The term viability has been used in this context to determine whether an organism is alive or dead. The use of vital and mortal stains to detect phytoplankton viability is a promising approach. In this study we investigated the efficiency of several vital and mortal dyes in detecting marine phytoplankton viability. Best results were achieved with neutral red, Evans blue and the fluorescent stain in tests with different percentages of live and dead cells. The combination of neutral red and Evans blue (vital and a mortal stains, respectively) was not effective in simultaneous analysis. Alexandrium tamiyavanichii had low affinity for any given stain. Different observational methods were compared, suggesting that direct microscopic counts can be replaced by image acquisition methods using either a microscope-mounted camera or a FlowCAM. Such imaging methods are fast, allow image archiving, and image processing can be performed on a later stage, which is useful when several experiments need to be run in a short period of time.
\end{abstract}

Key words: vital stains, phytoplankton counting, neutral red, Evans blue 


\subsection{Introdução}

Estudar a viabilidade do fito e zooplâncton é de importância ecológica e fisiológica, utilizada em diversos contextos, como em estudos de crescimento, de sobrevivência, de impactos ambientais e toxicidade (Garvey et al., 2007; Steinberg et al., 2011). Determinadas condições ambientais podem causar o comprometimento da membrana celular, a fragmentação do DNA, a degradação dos pigmentos e a redução da atividade fotossintética, resultando na morte do organismo (Veldhuis et al., 2001; Garvey et al., 2007). A viabilidade do fitoplâncton, entretanto, não é facilmente determinada, pois existem espécies sem motilidade ativa, ao contrário do zooplâncton, que pode ser detectado por seu movimento, por respostas de estímulos físicos, batimento cardíaco e natação (Sutherland et al., 2003; Steinberg et al., 2011).

De modo geral, as avaliações da viabilidade dependem de duas propriedades celulares: o estado fisiológico da célula (por exemplo, respiração celular ativa) e a permeabilidade da membrana (Coder, 1997). Uma maneira usual para determinar a viabilidade do fitoplâncton é avaliar a taxa de divisão celular, porém, um ambiente desfavorável pode inibir a reprodução apesar de a célula estar viva, inclusive sob a forma de cisto de resistência (Garvey et al., 2007).

Outro método comum é medir a autofluorescência da clorofila $a$ (Waite et al., 2003; Gavand et al., 2007). Entretanto, as moléculas de clorofila podem ficar intactas por até duas semanas após a morte do organismo e pode haver observações espúrias devido à clorofila detrital (Waite et al., 2003; Steinberg et al., 2011). Técnicas de cultivo e digestão celular também já foram usadas para testar a permeabilidade da membrana (Carney, 2011). Porém são métodos que demandam muito tempo de análise, tornando-os inviáveis para aplicações no biomonitoramento.

Outra maneira é a detecção da viabilidade celular através de corantes vitais e mortais, os quais são excluídos ou absorvidos pelas células devido às mudanças fisiológicas, morfológicas ou na permeabilidade da membrana celular (Steinberg, 2011; Zetsche \& Meysman, 2012).

Estudos importantes da viabilidade de organismos planctônicos por corantes tiveram início com Dressel et al. (1972), Crippen \& Perrier (1974) e Reynolds et al. (1978) para avaliação de células vivas e mortas de zooplâncton, fitoplâncton e algas estuarinas na presença de compostos químicos. 
Há dois tipos de corantes disponíveis para estudos sobre este tema: os vitais, que coram células vivas, e os mortais, que coram células mortas. Cada corante tem seu princípio ativo e coram diferentes estruturas celulares, como o DNA, lipídeos, lisossomos e enzimas subprodutos do metabolismo (Veldhuis et al., 2001; Dubrovsky et al., 2006; Steinberg et al., 2011; Govender et al., 2012). Devido a estas marcações específicas, fácil manipulação e visualização, a coloração tem se tornado uma técnica confiável e disseminada para a determinação da viabilidade celular.

Os reagentes mais utilizados são os corantes vitais vermelho neutro (Crippen \& Perrier, 1974; Dubrovsky et al., 2006; Elliott \& Tang, 2009; Zetsche \& Meysman, 2012), diacetato de fluoresceína (FDA) (Jones \& Senft, 1985; Steinberg et al., 2011, Carney, 2011), 5-clorometilfluoresceína diacetato (CMFDA) (Steinberg et al., 2011), e calceína (Hernlem \& Hua, 2010), assim como os corantes mortais azul de Evans (Crippen \& Perrier, 1974; Carney, 2011), azul de tripan (Coder, 1997; Carney, 2011), iodeto de propídio (PI) (Jones \& Senft, 1985) e SYTOX Green (Veldhuis et al., 2001). Entretanto, nem todos foram testados com sucesso em células de fitoplâncton.

Ultimamente têm sido testadas combinações de corantes. Steinberg et al. (2011) descreveram a combinação de dois corantes vitais, FDA e CMFDA, como um método robusto para a detecção da viabilidade de organismos planctônicos, pois foi mais eficiente na detecção de um número maior de espécies. Jones \& Senft (1985) testaram a combinação de diacetato de fluoresceína (FDA) com iodeto de propídio (PI) e conseguiram distinguir facilmente as células vivas e mortas.

Em relação à análise destas células, a microscopia é uma tecnologia bem reconhecida e utilizada há décadas. Entretanto, ao comparar com as novas tecnologias de visualização e contagem de células, é um método desfavorável devido ao tempo gasto nas contagens, principalmente para as amostras coradas, em que os corantes vão perdendo a coloração (Duhamel \& Jacquet, 2006). É necessário um devido preparo e atenção para manusear corretamente o filtro, as lâminas, o óleo de imersão e os corantes, para fazer a contagem correta das células (Hobbie et al., 1977). A FlowCAM vem sido utilizada como uma rápida e eficiente ferramenta para análises da comunidade planctônica, incluindo contagem de organismos, observação de comportamentos, medição dos tamanhos e emissão de fluorescência (Sieracki et al., 1998; Ide et al., 2008, Álvarez et al., 2011). 
Neste primeiro capítulo, o objetivo principal foi avaliar a eficácia de diferentes corantes vitais e mortais na detecção da viabilidade do fitoplâncton marinho em relação à concentração, tempo de coloração e aplicabilidade em espécies de diversos grupos taxonômicos. Os corantes testados foram vermelho neutro, azul de Evans, azul de tripan, calceína, CMFDA e SYTOX Green, para as espécies Alexandrium tamiyavanichii, Chattonella sp., Prorocentrum gracile, Tetraselmis gracilis e Thalassiosira pseudonana.

Além disso, foram avaliadas diferentes técnicas de observação e registro das células coradas e não coradas, como a visualização direta pela microscopia tradicional, captura de imagens através de câmera de vídeo instalada em um microscópio e captura de imagens por uma FlowCAM.

\subsection{Material e Métodos}

\subsubsection{Cultivos dos organismos}

As cepas de fitoplâncton utilizadas neste trabalho foram provenientes do Banco de Microorganismos Marinhos Aidar \& Kutner (BMA\&K) e do Laboratório de Sistemas Planctônicos (LAPS), ambos do Instituto Oceanográfico da USP.

Abaixo segue a lista das espécies escolhidas para os experimentos pertencentes a diferentes grupos taxonômicos e, consequentemente, de morfologias e comportamentos fisiológicos variados:

Classe Raphidophyceae

Ordem Chattonellales

Família Chattonellaceae

Chattonella sp. (Biecheler, 1936)

Classe Dinophyceae

Ordem Prorocentrales

Família Prorocentraceae

Prorocentrum gracile (Schütt, 1895) 
Classe Dinophyceae

Ordem Gonyaulacales

Família Goniodomataceae

Alexandrium tamiyavanichii (Belech, 1994)

Classe Chlorodendrophyceae

Ordem Chlorodendrales

Família Chlorodendraceae

Tetraselmis gracilis (Kylin, 1935 - Butcher, 1959)

Classe Bacillariophyceae

Ordem Thalassiosirales

Família Thalassiosiraceae

Thalassiosira pseudonana (Hasle \& Heimdal, 1970)

O cultivo destes microrganismos requer materiais e instalações físicas especiais para viabilizar a sua realização. Todas as cepas utilizadas foram mantidas no BMA\&K/IOUSP, local onde já existe a infraestrutura para os cultivos, como fluxo laminar (Pa 420 Eco - Pachane) para o preparo dos meios de cultura, câmaras de germinação com controle de temperatura, de fotoperíodo e de intensidade luminosa (Figs. 1.1 e 1.2).

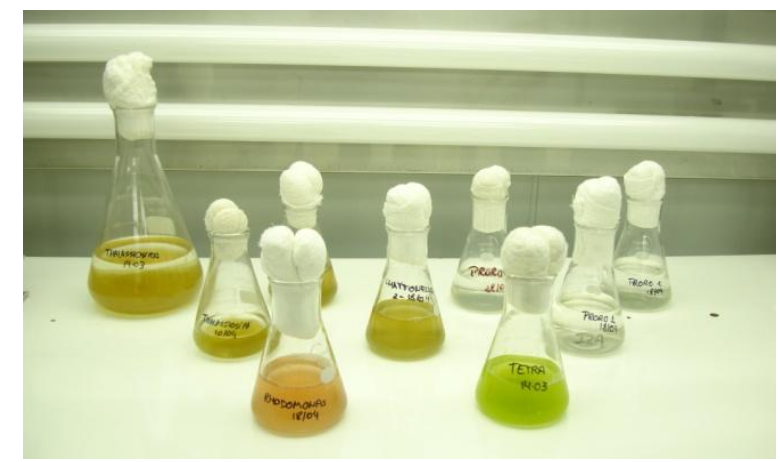

Figura 1.1. Câmara de germinação onde foram mantidas as culturas utilizadas, BMA\&K/IOUSP. 


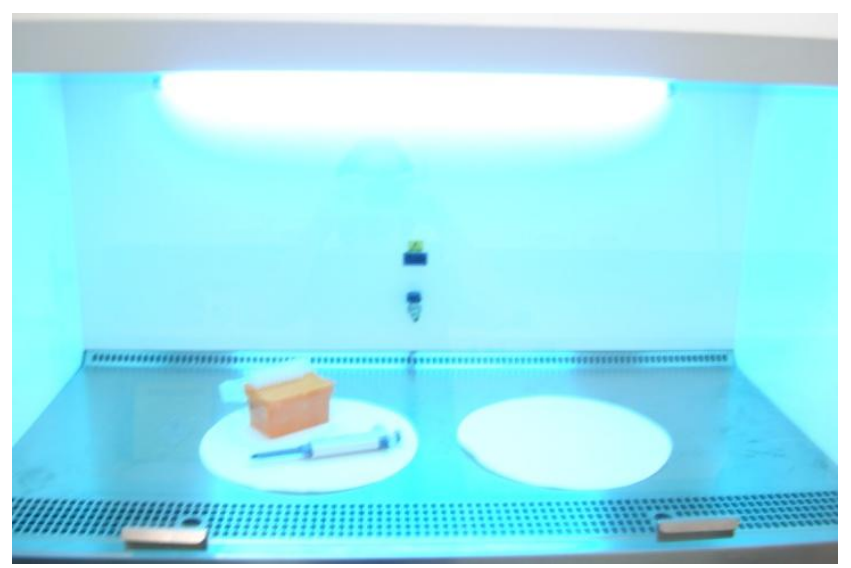

Figura 1.2. Fluxo laminar com o UV ligado para a esterilização do material utilizado no preparo dos cultivos, BMA\&K/IOUSP.

O meio de cultura utilizado foi o Guillard f/2 (Guillard, 1975; www.ncma.bigelow.org), exceto para os dinoflagelados A. tamiyavanichii e $P$. gracile, para os quais inicialmente foi utilizado o meio $\mathrm{f} / 4(0,5 \mathrm{~mL}$ de cada nutriente para cada 1L de meio, sem sílica), pois tiveram melhor crescimento nestas condições. Depois de três meses, estas espécies foram também mantidas em meio f/2.

Para todos os cultivos a salinidade da água do mar utilizada foi de 37, com temperatura de incubação de $23 \pm 1{ }^{\circ} \mathrm{C}$, intensidade luminosa de $180 \mu \mathrm{E} \mathrm{m}{ }^{2} \mathrm{~s}^{-1}$, e fotoperíodo de 12 horas.

Para a execução dos experimentos foram utilizados cultivos em fase exponencial de crescimento, partindo do pressuposto que a maioria das células nesta fase está viva. Como as espécies utilizadas são comumente mantidas no BMA\&K e LAPS/IOUSP e seus cultivos são exaustivamente descritos na literatura (Lourenço et al., 2002; Silva, 2013), já são conhecidas as curvas de crescimento destas cepas, o que facilitou a determinação do tempo para a fase exponencial e para repicagem do cultivo.

O material utilizado foi devidamente lavado com detergente neutro (1\%), mantido em contato com ácido clorídrico $(\mathrm{HCl})$ a $10 \%$ por um período de 24 horas, lavado em água corrente da torneira e depois em água destilada, e seco em estufa a 60 ${ }^{\circ} \mathrm{C}$. Antes do preparo de um novo cultivo, o material foi esterilizado em autoclave $\left(121^{\circ} \mathrm{C}, 1 \mathrm{~atm}, 40\right.$ minutos) e seco em estufa a $60{ }^{\circ} \mathrm{C}$. Todo este procedimento foi baseado em Kawachi \& Noël (2005) e Lourenço (2006). 


\subsubsection{Preparo dos corantes}

\section{Corantes não fluorescentes}

As soluções estoque dos corantes vermelho neutro (Fluka, Sigma Aldrich) e azul de Evans (Sigma Aldrich) foram preparadas a 1\% em água destilada. O corante azul de tripan (Sigma Aldrich) foi preparado a 0,4\% com o solvente PBS (tampão

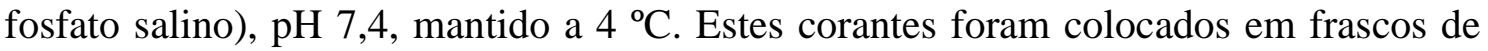
vidro âmbar de $100 \mathrm{~mL}$ de capacidade, protegidos da luz com papel alumínio e armazenados a $4{ }^{\circ} \mathrm{C}$. A recomendação é de substituir a solução estoque mensalmente (Elliott \& Tang, 2009), porém, neste trabalho obtivemos bons resultados de coloração com soluções estoque de até três meses de uso. As concentrações das soluções foram baseadas em recomendações de estudos anteriores (Tabela 1.1).

Tabela 1.1. Informações dos corantes biológicos não fluorescentes utilizados.

\begin{tabular}{cccc}
\hline TIPO DE CORANTE & ALVO & $\begin{array}{c}\text { SOLUÇÃo } \\
\text { ESTOQUE }\end{array}$ & REFERÊNCIA \\
\hline Vermelho neutro & $\begin{array}{c}\text { Tomado por endocitose } \\
\text { pelos vacúolos }\end{array}$ & $1 \%$ & Elliott \& Tang (2009) \\
Azul de Evans & $\begin{array}{c}\text { Entrada em células com } \\
\text { membrana comprometida }\end{array}$ & $1 \%$ & Crippen \& Perrier (1974) \\
& $\begin{array}{c}\text { Entrada em células com } \\
\text { Azul de tripan }\end{array}$ & $0,4 \%$ & Coder (1997) \\
\hline
\end{tabular}

\section{Observações microscópicas qualitativas}

Foram notadas algumas modificações nas células após a adição do corante vermelho neutro. Devido a isso, alguns testes adicionais foram feitos para verificar se as células eram sensíveis a qualquer perturbação do experimento ou se era algum efeito do corante. 2,0 mL de amostras da espécie Chattonella sp., espécie a qual teve maiores variações, foram colocadas em mini placas de Petri de vidro (5 $\mathrm{cm}$ de diâmetro), nas quais foram submetidas a diversos tratamentos. Para testar efeitos no movimento, foram aplicadas duas gotas de formol $40 \%$. Em seguida, foi feito um teste de simulação da alteração do $\mathrm{pH}$ na amostra, aplicando $1,5 \mu \mathrm{L}$ de $\mathrm{HCl} 10 \%$ e aproximadamente $1 \mathrm{mg}$ de 
borato de sódio em cada $1 \mathrm{~mL}$ de amostra. Por último, foram comparadas soluções de vermelho neutro preparadas com água destilada (segundo o método normalmente utilizado) e com água do mar filtrada com filtro de papel (330 mm, $80 \mathrm{mg})$, para avaliar possíveis efeitos da baixa salinidade da solução do corante sobre a espécie.

\section{Corantes fluorescentes}

O corante mortal SYTOX Green (Invitrogen) foi comprado em estado líquido (30 $\mu \mathrm{M}$, em $1 \mathrm{~mL}$ DMSO) e pronto para uso. Os corantes calceína e CMFDA foram ressuspendidos com o solvente DMSO (dimetilsufóxido/ Life Technologies, Molecular Probes) para $1 \mathrm{mM}$ e $10 \mathrm{mM}$, respectivamente. Os três corantes foram armazenados a $20{ }^{\circ} \mathrm{C}$. As concentrações de uso das soluções foram baseadas em recomendações da literatura (Tabela 1.2).

Tabela 1.2. Informações dos corantes biológicos fluorescentes utilizados.

\begin{tabular}{cccc}
\hline $\begin{array}{c}\text { TIPO DE } \\
\text { CORANTE }\end{array}$ & ALVO & $\begin{array}{c}\text { SOLUÇÃo } \\
\text { ESTOQUE }\end{array}$ & REFERÊNCIA \\
\hline Calceína & $\begin{array}{c}\text { Enzimas esterases, subproduto da } \\
\text { respiração }\end{array}$ & $1 \mathrm{mM}$ & Hernlem \& Hua \\
CMFDA & Enzimas extracelulares & $10 \mathrm{mM}$ & $\begin{array}{c}\text { Steinberg et al. } \\
(2011)\end{array}$ \\
SYTOX Green & $\begin{array}{c}\text { Células com membrana comprometida, } \\
\text { coloração do DNA }\end{array}$ & $30 \mu \mathrm{M}$ & Carney (2011) \\
\hline
\end{tabular}

\subsubsection{Teste de viabilidade}

Teste do tempo de coloração

Os testes do tempo de coloração foram feitos somente com os corantes não fluorescentes (vermelho neutro e azul de Evans), pois havia uma maior variabilidade entre eles em estudos anteriores (Crippen \& Perrier, 1974; Elliott \& Tang, 2009; Carney, 2011) em relação ao tempo de ação para organismos em cultivo. Para os corantes fluorescentes, há referências mais recentes (Veldhuis et al., 2001; Hernlem \& Hua, 2010; Steinberg et al., 2011), as quais foram usadas para a escolha dos tempos de ação. 
As amostras foram retiradas no fluxo laminar, com auxílio de pipetas automáticas esterilizadas, diretamente do frasco de cultivo e colocadas em placas multipoços de acrílico (4 x 6) no volume total de $1 \mathrm{~mL}$ por poço (Fig. 1.3). Quando necessário, principalmente para as culturas mais densas (como $T$. gracilis e $T$. pseudonana), foram feitas diluições com o próprio meio de cultura, resultando em uma concentração em torno de $8 \times 10^{3}$ cel. $\mathrm{mL}^{-1}$. As células coradas e não coradas foram contadas em câmaras de contagem manualmente. Este procedimento será detalhado na seção 1.2.4. Técnicas de observação e registro das células.

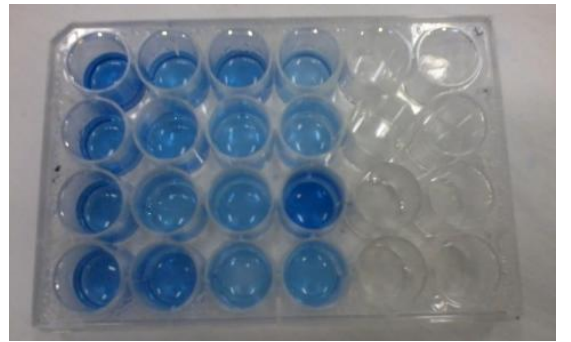

Figura 1.3. Placa multipoços de acrílico com amostras de fitoplâncton coradas com o azul de Evans.

Foram determinados os seguintes tempos de coloração para o teste com o vermelho neutro: 1, 5, 10, 15, 20, 30, 40 e 60 minutos; e com o azul de Evans: 20, 30, 40, 50, 60 e 70 minutos. Para cada tempo testado foram feitas quatro réplicas.

Para o teste do corante mortal azul de Evans cada réplica foi submetida a um banho-maria (Nalgon Equipamentos Científicos) a $80{ }^{\circ} \mathrm{C}$ por 15 minutos para a morte das células. Vale ressaltar que esta temperatura não provocou o rompimento das células.

O azul de tripan não foi testado, pois ele não mostrou compatibilidade de coloração nos organismos cultivados nos testes pilotos. 


\section{Teste de eficácia de coloração}

Para testar a eficácia de cada corante, cinco tratamentos foram realizados com diferentes proporções de células vivas e mortas: 0\%, 25\%, 50\%, 75\% e 100\% (Tabela 1.3). Para os tratamentos que foram usados os corantes vitais, esta porcentagem sempre está relacionada às células vivas, enquanto que para os corantes mortais, a porcentagem é relacionada às células mortas.

As amostras foram retiradas com pipetas automáticas diretamente do frasco de cultivo e colocadas em placas multipoços de acrílico $(4 \times 6)$ no volume total de $1 \mathrm{~mL}$ por poço (Figura 1.3). Após o banho-maria e em temperatura ambiente, o volume de cada poço foi completado com as células vivas, seguindo a proporção desejada (Tabela $1.3)$.

Em seguida, os corantes foram colocados com pipetas automáticas e aguardado o tempo de ação de cada um deles (Tabela 1.4). Cada tratamento foi composto por quatro réplicas.

Para este teste de viabilidade, as células com os corantes não fluorescentes foram observadas através dos métodos: microscopia tradicional, filmagem e captura de imagens pela FlowCAM. As células com os corantes fluorescentes foram observadas somente por microscópio de epifluorescência. Estes procedimentos serão explicados no tópico 1.2.4. Técnicas de observação e registro das células.

Tabela 1.3. Tratamentos testados com proporções de volumes de alíquotas com células vivas e mortas, em relação a $1 \mathrm{~mL}$ de amostra. $\mathrm{Na}$ tabela, as porcentagens estão relacionadas às células vivas, na fase exponencial de crescimento.

\begin{tabular}{ccc}
\hline TRATAMENTOS & $\begin{array}{c}\text { VOLUME DA ALíQUOTA } \\
\text { COM CÉLULAS VIVAS }(\mathrm{mL})\end{array}$ & $\begin{array}{c}\text { VOLUME DA ALíQUOTA COM } \\
\text { CÉLULAS MORTAS (mL) }\end{array}$ \\
\hline $0 \%$ & 0 & 1,00 \\
$25 \%$ & 0,25 & 0,75 \\
$50 \%$ & 0,50 & 0,50 \\
$75 \%$ & 0,75 & 0,25 \\
$100 \%$ & 1,00 & 0 \\
\hline
\end{tabular}


Tabela 1.4. Volumes e tempos de coloração utilizados para cada corante nos testes da eficácia de coloração. $\mathrm{O}$ volume do corante é referente para $1 \mathrm{~mL}$ de amostra.

\begin{tabular}{ccccr}
\hline TIPO DE CORANTE & $\begin{array}{c}\text { CONCENTRAÇÃo } \\
\text { DO CORANTE NA } \\
\text { AMOSTRA }\end{array}$ & VOLUME & $\begin{array}{c}\text { TEMPO DE } \\
\text { COLORAÇÃo } \\
\text { (minutos) }\end{array}$ & REFERÊNCIA \\
\hline CORANTE VITAL & & & & \\
\hline Vermelho neutro & $1,5 \mu \mathrm{M}$ & $1,5 \mu \mathrm{L}$ & 20 & Elliott \& Tang (2009) \\
Calceína & $10 \mu \mathrm{M}$ & $10 \mu \mathrm{L}$ & 30 & Hernlem \& Hua (2010) \\
CMFDA & $2,5 \mu \mathrm{M}$ & $10 \mu \mathrm{L}$ & 20 & Steinberg et al. (2011) \\
\hline CORANTE MORTAL & & & & Crippen \& Perrier (1974) \\
\hline Azul de Evans & $0,5 \mu \mathrm{M}$ & $3,5 \mu \mathrm{L}$ & 20 & Carney (2011) \\
SYTOX Green & $0,5 \mu \mathrm{M}$ & $16,7 \mu \mathrm{L}$ & 20 & \\
\hline
\end{tabular}

\section{Teste de combinação de corantes}

A combinação de corantes vitais e mortais teve como objetivo avaliar a possibilidade de identificar em uma mesma contagem células vivas e mortas, permitindo maior eficiência do método de coloração.

O teste de combinação de corantes só foi possível com os corantes vermelho neutro e azul de Evans, pois os corantes fluorescentes emitem a mesma cor verde, o que impossibilitaria distinguir células vivas e mortas. Não foram feitas combinações entre corantes fluorescentes e não fluorescentes, pois não havia disponibilidade de um método eficaz de observação simultânea para células com e sem fluorescência.

As espécies $T$. pseudonana e $P$. gracile foram escolhidas para o estudo comparativo de eficácia da combinação entre vermelho neutro e azul de Evans. Volumes iguais $(1 \mathrm{~mL})$ das culturas na fase exponencial foram colocados em três poços da placa multipoço, aos quais foram adicionados os corantes vermelho neutro, azul de Evans e a combinação vermelho neutro + azul de Evans, respectivamente. No quarto poço foi colocado $1 \mathrm{~mL}$ de cultura mista, com $50 \%$ do volume de cultura na fase exponencial e $50 \%$ do volume de cultura morta por aquecimento. Neste poço foi adicionada a mistura dos corantes e, portanto, o esperado era obter $50 \%$ de células 
coradas por vermelho e $50 \%$ de células coradas em azul. Todos os testes foram feitos em duplicata.

Após 20 minutos da adição dos corantes, as amostras foram contadas em câmara de contagem através de microscópio, discriminando células coradas e não coradas.

\subsubsection{Técnicas de observação e registro de células}

\section{Microscopia tradicional}

Após os devidos tempos de ação de cada corante, as amostras foram transferidas com pipetas Pasteur de vidro para a câmara Nageotte (hemocitômetro com capacidade de $50 \mu \mathrm{L}$ em cada campo de contagem) e contadas sob microscópio Olympus BX50 (objetiva 20x) com o auxílio de contadores manuais. As contagens foram realizadas discriminando as células coradas e não coradas.

Para as observações e contagem dos corantes fluorescentes foram utilizados o microscópio invertido de epifluorescência Nikon Eclipse TS100 (objetiva 20x, filtro B2E/ C FITC) e o microscópio Olympus BX51, no qual foi possível fazer fotografias das células fluorescentes.

No microscópio foi feita a contagem de toda a câmara Nageotte, exceto para as espécies com maiores densidades celulares (T. gracilis e T. pseudonana), que neste caso foram contadas até o máximo de 400 células (Lourenço, 2006), mesmo após diluição.

\section{Filmagem e aquisição de imagens}

Contagens adicionais foram realizadas através de filmagens das câmaras de contagem no microscópio multizoom Nikon AZ100, com câmera de vídeo (Sony 3CCD ExwaveHAD) e o programa analisador de imagens CaptureFlux (6.0.5) (Fig. 1.4).

As filmagens foram utilizadas para analisar os testes de eficácia e de tempo de coloração dos corantes vermelho neutro e azul de Evans. Não foi possível capturar imagens através de filmagens nos experimentos com os corantes fluorescentes.

Cada vídeo foi feito filmando as linhas da câmara Nageotte aleatoriamente por 1 minuto, a fim de padronizar um tempo máximo de contagem. As imagens geradas foram tratadas no programa MatLab 7.8.0 (R2009a) para extração dos quadros. Os 
quadros foram visualizados no programa Microsoft Office Picture Manager e as células coradas e não coradas foram contadas manualmente.

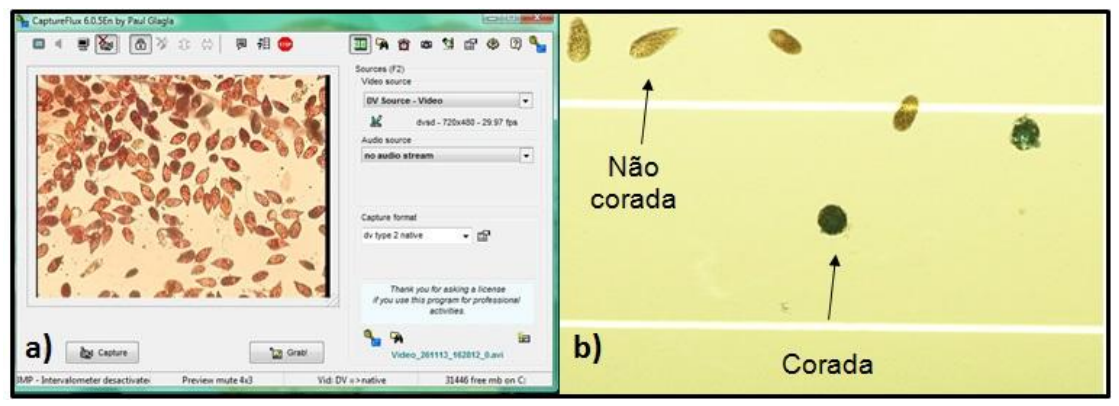

Figura 1.4. a) Software CaptureFlux 6.0.5 (Paul Glagla) utilizado para a filmagem das células; b) Exemplo de um quadro extraído.

\section{FlowCAM}

Para a análise na FlowCAM (Modelo VS-VI 2008; Software: VisualSpreadsheet 2.2.7) foi necessário diluir as amostras em $10 \%$ para viabilizar as contagens de forma a evitar o entupimento da célula de fluxo (escolhida a de $100 \mu \mathrm{m}$ de profundidade). Para as espécies de menor densidade celular, como $P$. gracile, foi feita diluição de 5\% em água do mar filtrada.

Antes da análise de cada amostra, a célula de fluxo foi limpa com hipoclorito de sódio $10 \%$, água destilada e água do mar filtrada. Foi utilizada a objetiva de 10x, frequência de 7 quadros/ segundo e operada no modo AutoImagem. Para a captura de imagens, foi utilizada a menor velocidade da bomba peristáltica (Forward Slow) e cada amostra foi analisada pela FlowCAM durante 3 minutos.

A classificação foi baseada em bibliotecas de imagens formadas por três grupos: células coradas, células não coradas e outros (incluindo detritos de tamanhos pequeno e grande), os quais foram excluídos da contagem final.

As espécies analisadas na FlowCAM foram a T. gracilis e T. pseudonana para o vermelho neutro, e Chattonella sp. e P. gracile para o azul de Evans. 


\section{Resumo das técnicas}

Os experimentos de eficácia do vermelho neutro e azul de Evans foram os únicos realizados pelas três técnicas de observação. Desta forma, os resultados das contagens destes experimentos foram comparados através da análise de correlação linear, baseando-se nos resultados da contagem manual através da microscopia, conhecida como técnica padrão e tradicional de contagem de fitoplâncton.

$\mathrm{Na}$ tabela a seguir, está o resumo das características de cada técnica e quais experimentos foram analisados por elas. Vale ressaltar que foi feito um experimento de eficácia de corantes para cada técnica, ou seja, uma mesma amostra não foi analisada mais de uma vez por técnicas diferentes.

Tabela 1.5. Resumo das características de cada técnica de observação e registro das células de fitoplâncton usadas neste trabalho.

\begin{tabular}{|c|c|c|c|}
\hline $\begin{array}{c}\text { TÉCNICAS/ } \\
\text { CARACTERÍSTICAS }\end{array}$ & MICROSCOPIA & VÍDEO & FLOWCAM \\
\hline Observação & Direta & $\begin{array}{c}\text { Indireta } \\
\text { (Imagens) }\end{array}$ & $\begin{array}{c}\text { Indireta } \\
\text { (Imagens) }\end{array}$ \\
\hline Registro & Manual & Manual & Automático \\
\hline Experimento & $\begin{array}{l}\text { Eficácia dos corantes } \\
\text { fluorescentes e não } \\
\text { fluorescentes }\end{array}$ & $\begin{array}{c}\text { - Tempo de coloração } \\
\text { - 2x Eficácia } \\
\text { (ambos do VN e EB) }\end{array}$ & Eficácia do VN e EB \\
\hline
\end{tabular}

\subsection{Resultados}

\section{Corantes vitais}

\subsubsection{Vermelho neutro}

O corante vital vermelho neutro teve afinidade com quatro das cinco espécies testadas. O tempo de coloração foi relativamente rápido sendo que de poucos minutos a até mais de uma hora muitas células exibiram e mantiveram a coloração. O corante só não foi eficiente para amostras com alta densidade celular (acima de $10^{4}$ cel. $\mathrm{mL}^{-1}$ ), principalmente de células de pequeno tamanho, como $T$. gracilis. 


\section{Observações microscópicas qualitativas}

Embora não tenham sido feitas observações quantitativas, notou-se uma diminuição da atividade natatória das células de fitoplâncton ao aplicar o vermelho neutro nas amostras. Em testes com a espécie Chattonella sp., foi visto ruptura da membrana e lise celular após poucos minutos (em geral após 5 minutos) de ação do corante (Fig. $1.5 \mathrm{a}, \mathrm{b})$.

Testes para observações qualitativas demonstraram que as variações morfológicas e na movimentação das células aparentemente foram causadas pelo efeito do corante e não por nenhuma modificação de $\mathrm{pH}$ ou salinidade. Todos os testes com adição de formol, $\mathrm{HCl}$ (Fig. 1.5c), borato de sódio e mudança de salinidade (Fig. 1.5d) não provocaram as mesmas alterações morfológicas e comportamentais das células como com a adição do corante. Visualmente as células ficaram paradas e em formato arredondado, porém sem lise (Fig. 1.5c, d). Somente após 1 hora na solução com o borato de sódio que foi notada a ruptura da membrana celular.

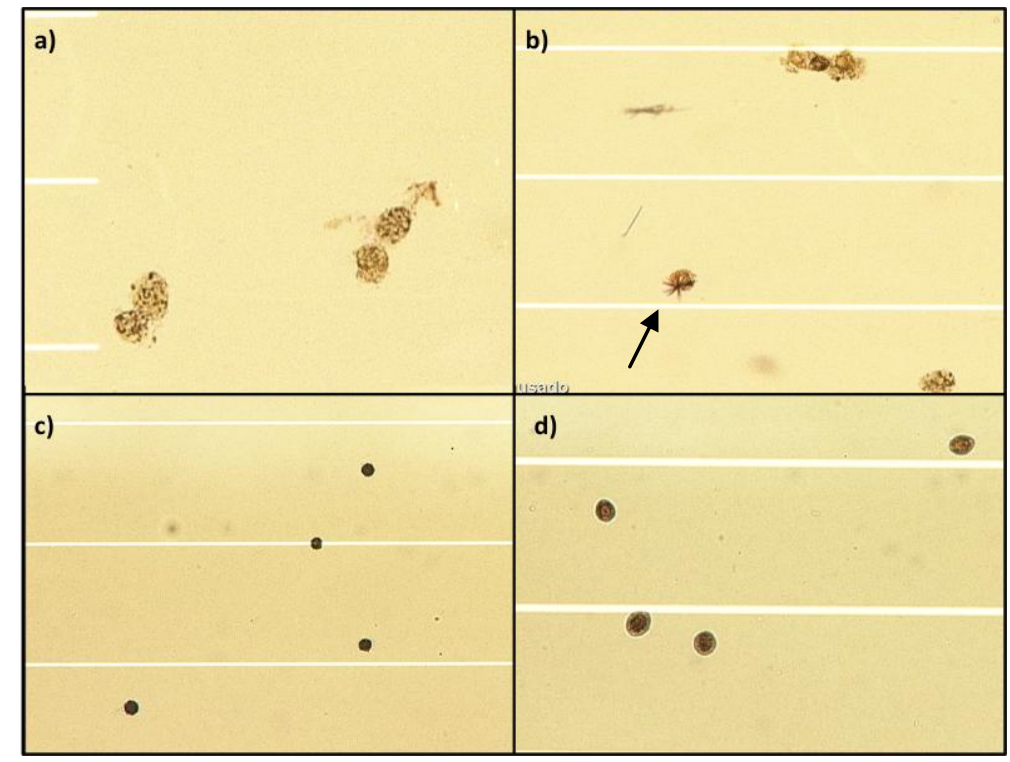

Figura 1.5. Imagens de Chattonella sp. em diversas condições: a) Ação do vermelho neutro após 20 minutos, as células estão lisadas, com pouco conteúdo celular; b) Ação do vermelho neutro após 30 minutos: além da lise das células, há formação de cristais (seta); c) Resultado da ação de $\mathrm{HCl} 10 \%$, as células ficaram menores, arredondadas, mas não apresentaram aspecto de lise celular; d) Resultado da adição de água destilada na amostra, nenhuma célula rompida. 


\section{Tempo de coloração}

Para as espécies testadas, o vermelho neutro teve melhor eficácia após 40 minutos de ação, ou seja, após este tempo quase $100 \%$ das células presentes estavam coradas e esta porcentagem permaneceu estável (Fig. 1.6). Apesar disso, a partir de 20 minutos já foi notado um resultado satisfatório do corante para as espécies $T$. gracilis e T. pseudonana que tiveram média de $100 \%$ de células coradas, e para $P$. gracile com média acima de $60 \%$, sendo que uma das réplicas apresentou $80 \%$ de coloração. Por este motivo, este tempo foi o escolhido para o tempo mínimo de coloração do vermelho neutro (Fig. 1.6).

As espécies $T$. gracilis, $P$. gracile e $T$. pseudonana tiveram maior afinidade com o corante, pois mais de $80 \%$ das células vivas presentes foram coradas. $T$. pseudonana, em particular, teve alta afinidade com o corante desde o primeiro minuto de ação, mantendo $100 \%$ de células coradas durante todo o tempo testado (Fig. 1.6).

Entretanto, A. tamiyavanichii teve a maior porcentagem de células coradas no tempo de 10 minutos. Após este tempo, houve uma queda da porcentagem de coloração (Fig. 1.6).

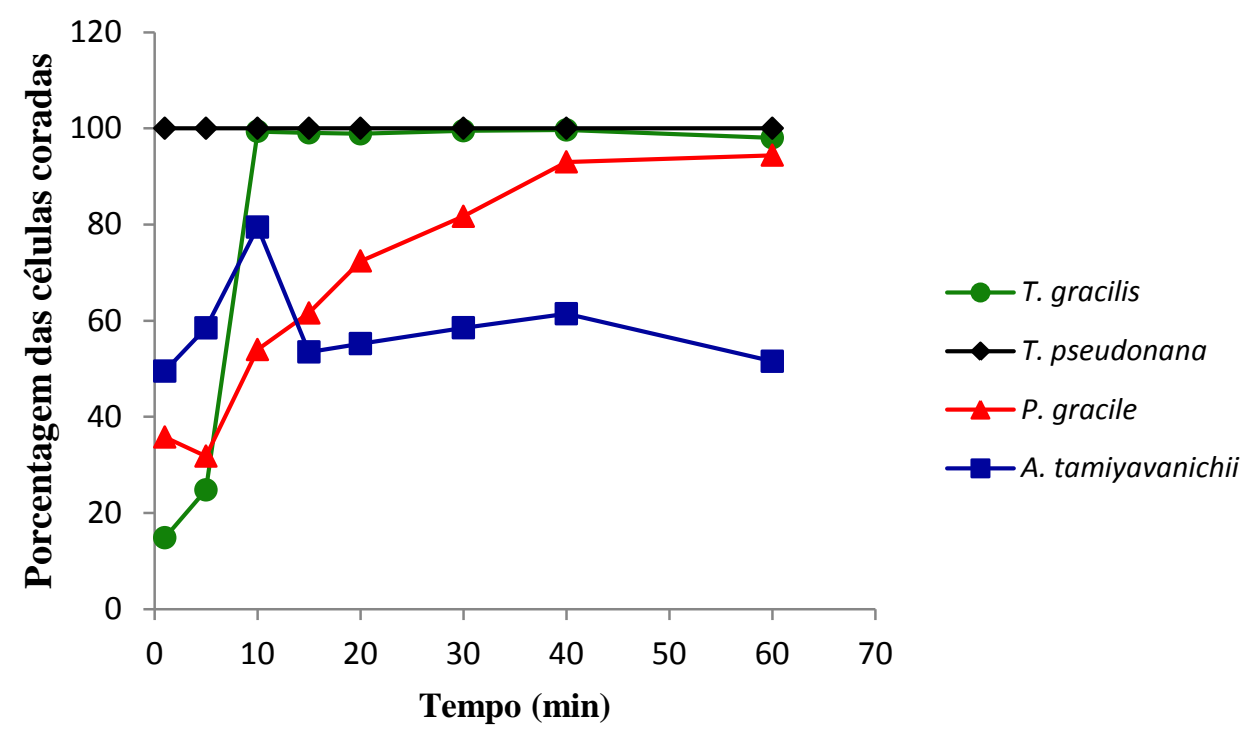

Figura 1.6. Comparação entre os tempos de coloração do vermelho neutro e a média das porcentagens de células coradas entre as diferentes espécies testadas. 


\section{Eficácia do corante}

O vermelho neutro foi eficiente para detectar T. gracilis, T. pseudonana e P.gracile, as quais tiveram proporções de células coradas próximas do esperado (Fig. 1.7). A espécie A. tamiyavanichii teve proporções observadas abaixo do esperado e altos desvios padrão (Fig. 1.7).

$\mathrm{Na}$ figura 1.7, juntamente às médias foram plotadas as medianas de cada conjunto de amostras por tratamento, a fim de verificar a tendência do número central observado, para melhor avaliar os desvios padrão.

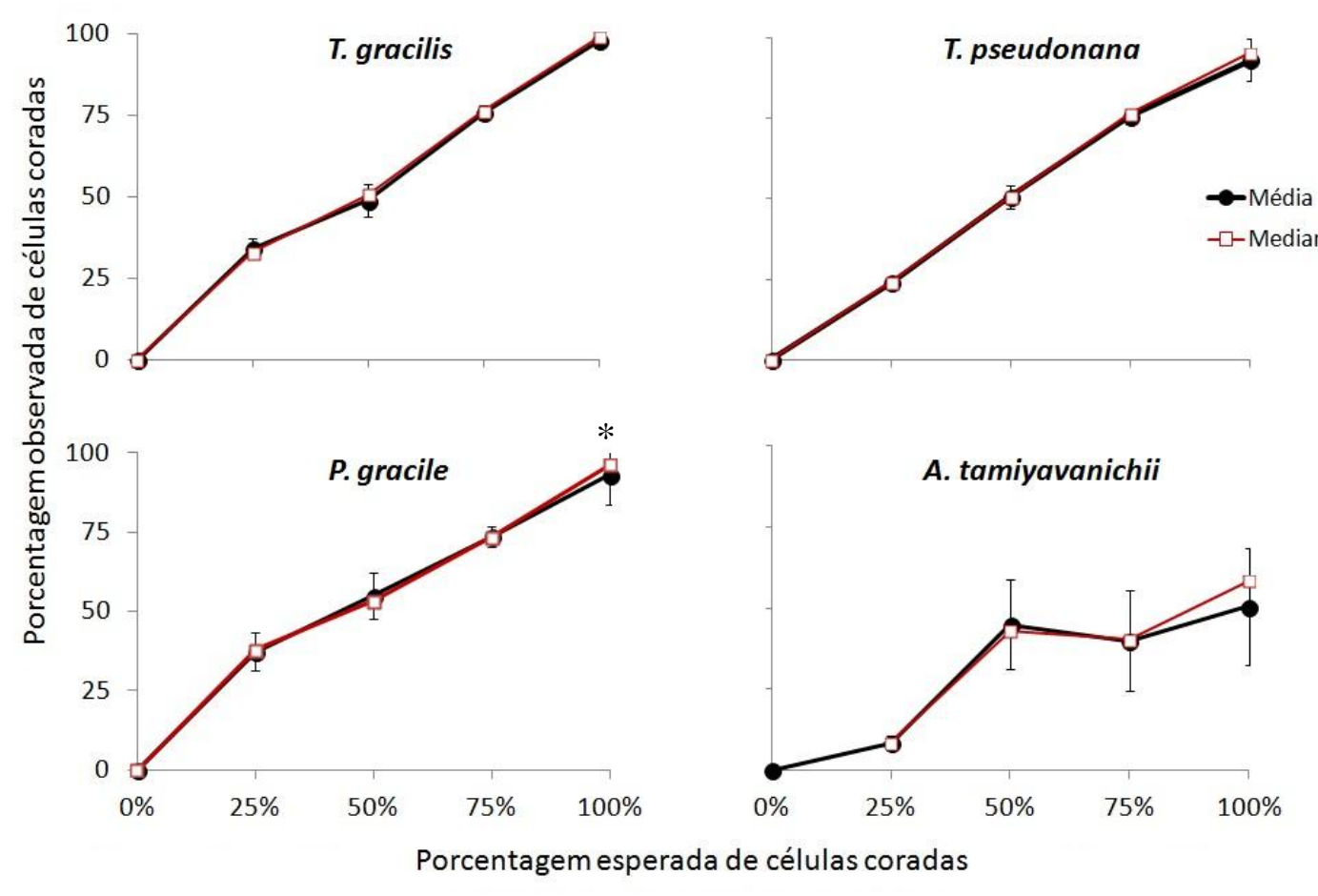

Figura 1.7. Relação entre as médias (preto) observadas de células vivas coradas por vermelho neutro e a porcentagem esperada por espécie testada. Em vermelho, estão representadas as medianas de cada conjunto de réplicas. As barras verticais representam o desvio padrão. $\mathrm{O} *$ indica que o desvio padrão ultrapassou a área do gráfico representada. 


\section{Padrão de coloração}

Muitas vezes a coloração implicou em dúvidas de como padronizar o que estava corado e não corado, principalmente para os dinoflagelados. Na figura a seguir, estão exemplos de imagens que foram consideradas células vivas (coradas) e células mortas (não coradas) para o corante vermelho neutro.

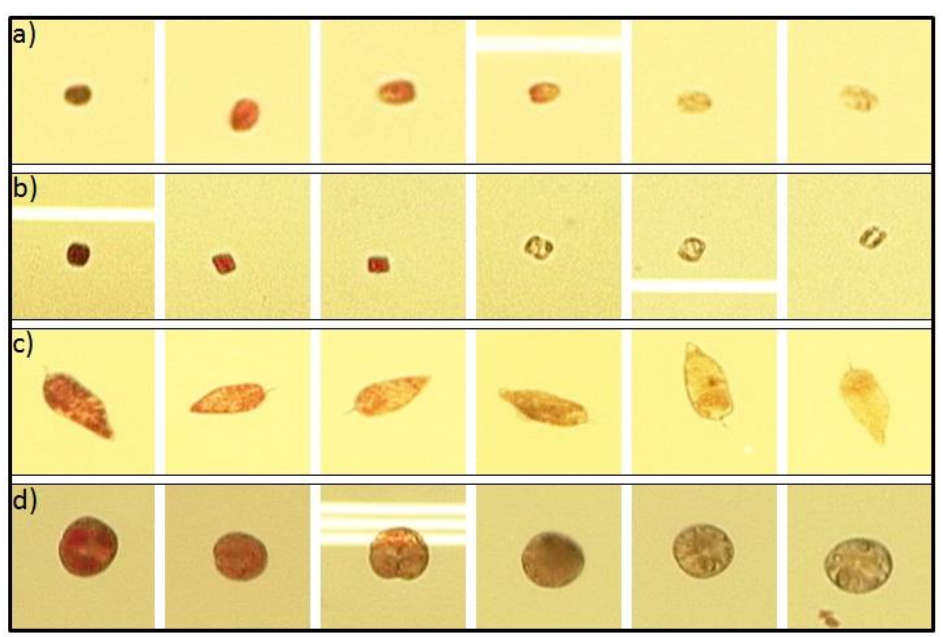

Figura 1.8. Padrão de coloração usado para distinguir células coradas e não coradas com o corante vermelho neutro. Na linha a) $T$. gracilis, até a $4^{\mathrm{a}}$ imagem: células coradas; b) $T$. pseudonana, até a $3^{\mathrm{a}}$ imagem: células coradas; c) P. gracile e d) A. tamiyavanichii, até $4^{\mathrm{a}}$ imagem foram consideradas coradas.

\subsubsection{Calceína}

O tempo ideal de coloração da calceína foi a partir de 30 minutos, porém ela não foi efetiva para todos os grupos testados. Após 12 horas de ação do corante, a solução fica verde e as células perdem a coloração. $\mathrm{O}$ uso de formol ou $\mathrm{HCl}$ para imobilizar as células vivas (para facilitar a contagem), bloqueou o sinal do corante. Além disso, foi necessário usar todo o ganho de luz da fonte para visualizar a fluorescência.

A espécie Chattonella sp. foi eficiente para os tratamentos $0 \%$ e $100 \%$ vivas, desta forma, provou a especificidade da calceína em marcar somente as células vivas. Entretanto, para as outras proporções de células os resultados não foram eficientes, 
principalmente para os tratamentos de $50 \%$ e $75 \%$ de células vivas, o que pode inferir algum erro amostral ou de procedimento (Fig. 1.9).

No caso da T. pseudonana, apesar das porcentagens observadas serem muito abaixo do esperado, houve uma coerência de resultados. Observou-se um aumento das células coradas de acordo com os tratamentos esperados (Fig. 1.9).

Os dinoflagelados, entretanto, tiveram número significativo de células coradas para o tratamento de $0 \%$ de células vivas. Apesar disso, $P$. gracile apresentou coerência de resultados nas outras proporções, apesar de ser abaixo do esperado.

A. tamiyavanichii não apresentou nenhum padrão de coloração em relação ao esperado. Ao contrário, as porcentagens de células coradas observadas foram inversamente proporcionais ao esperado. Além disso, no tratamento de $100 \%$ de células vivas apresentou o menor número de células coradas de todos os tratamentos. Foi a espécie que teve maiores variações de resultados entre as réplicas (Fig. 1.9).

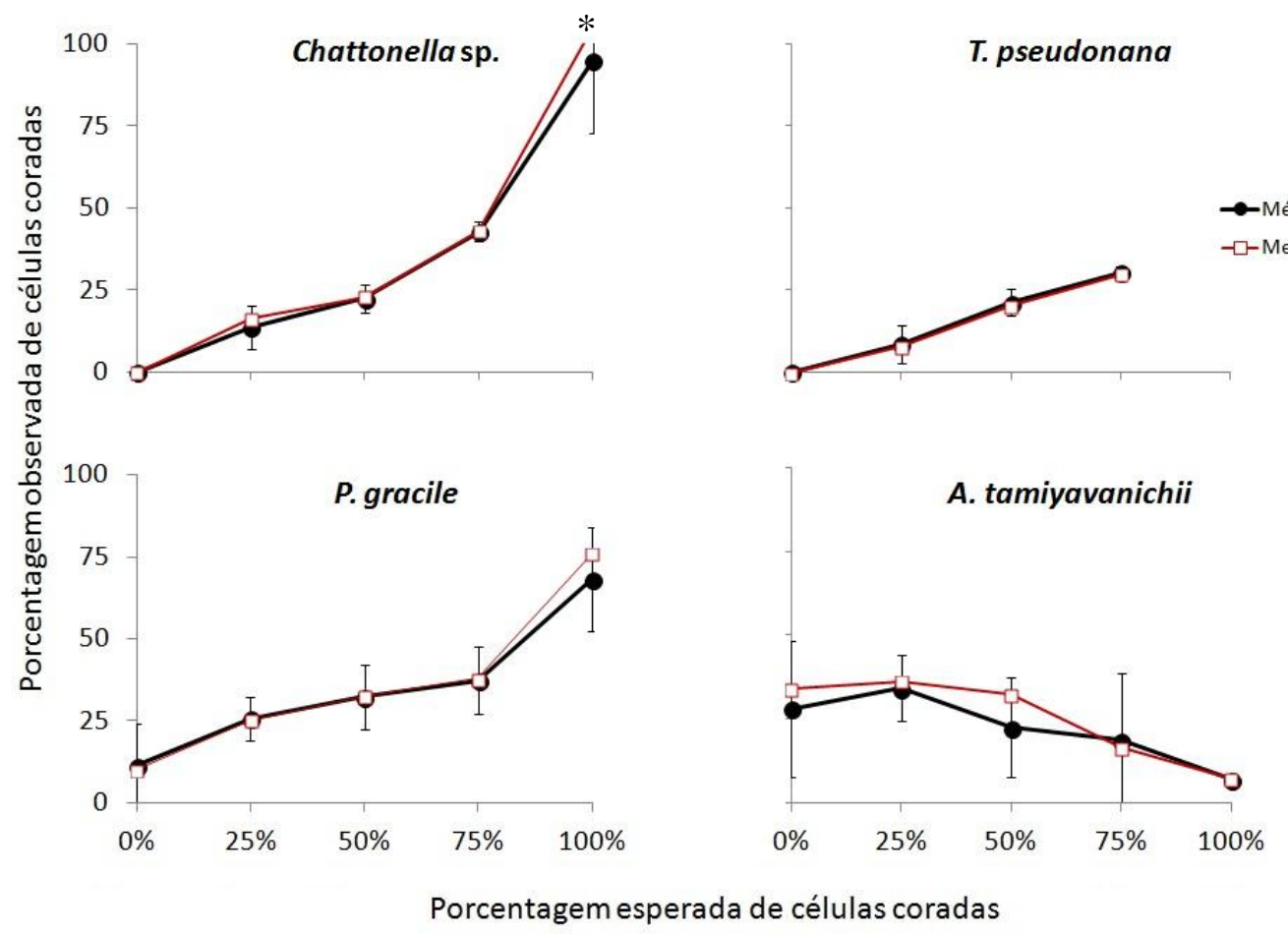

Figura 1.9. Relação entre as médias (preto) observadas de células vivas coradas por calceína e a porcentagem esperada por espécie testada. Em vermelho, estão representadas as medianas de cada conjunto de réplicas. As barras verticais representam o desvio padrão. Não há dados de contagem para a espécie T. pseudonana no tratamento de $100 \%$ de células vivas, devido à dificuldade de visualização e distinção para a contagem. $\mathrm{O} *$ indica que o desvio padrão ultrapassou a área do gráfico representada. 


\section{Padrão de coloração}

A seguir, imagens das células vivas e coradas pelo corante fluorescente vital calceína ( $1^{\mathrm{a}}$ coluna, fundo preto $)$ e células mortas não coradas ( $2^{\mathrm{a}}$ coluna).

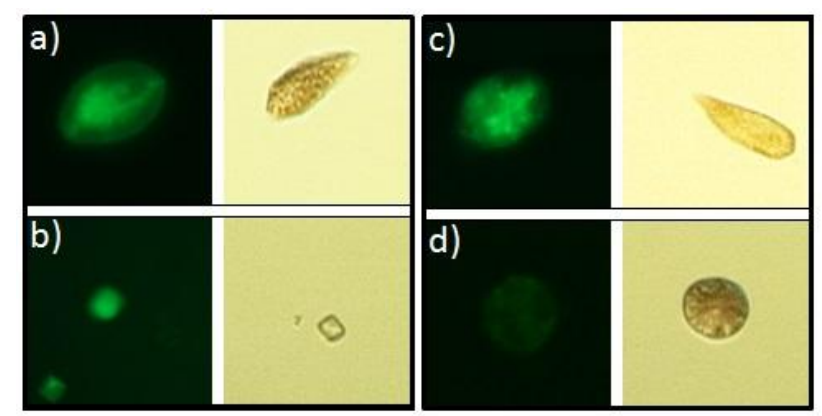

Figura 1.10. Imagens das células coradas pela calceína (vivas $-1^{a}$ coluna, fundo preto) e não coradas (mortas $-2^{\mathrm{a}}$ coluna). Em a) Chattonella sp. $(30-40 \mu \mathrm{m})$; b) T. pseudonana $(7-11$ $\mu \mathrm{m})$; c) P. gracile $(40-50 \mu \mathrm{m})$ e d) A. tamiyavanichi $(30-40 \mu \mathrm{m})$.

\subsubsection{CMFDA}

O corante CMFDA teve afinidade com todas as espécies testadas, no entanto, as porcentagens observadas de células coradas foram um pouco abaixo do esperado (Fig. 1.11). Além disso, todas as espécies tiveram altos desvios padrão entre as réplicas, o que demanda de mais estudos com este corante.

A espécie A. tamiyavanichii foi exceção, pois teve resultados fora do padrão esperado. Isto é comprovado pelo tratamento de $0 \%$ de células vivas onde teve uma média de $66 \%$ de coloração, mais do que o observado no tratamento de $75 \%$ de células vivas (Fig. 1.11). 


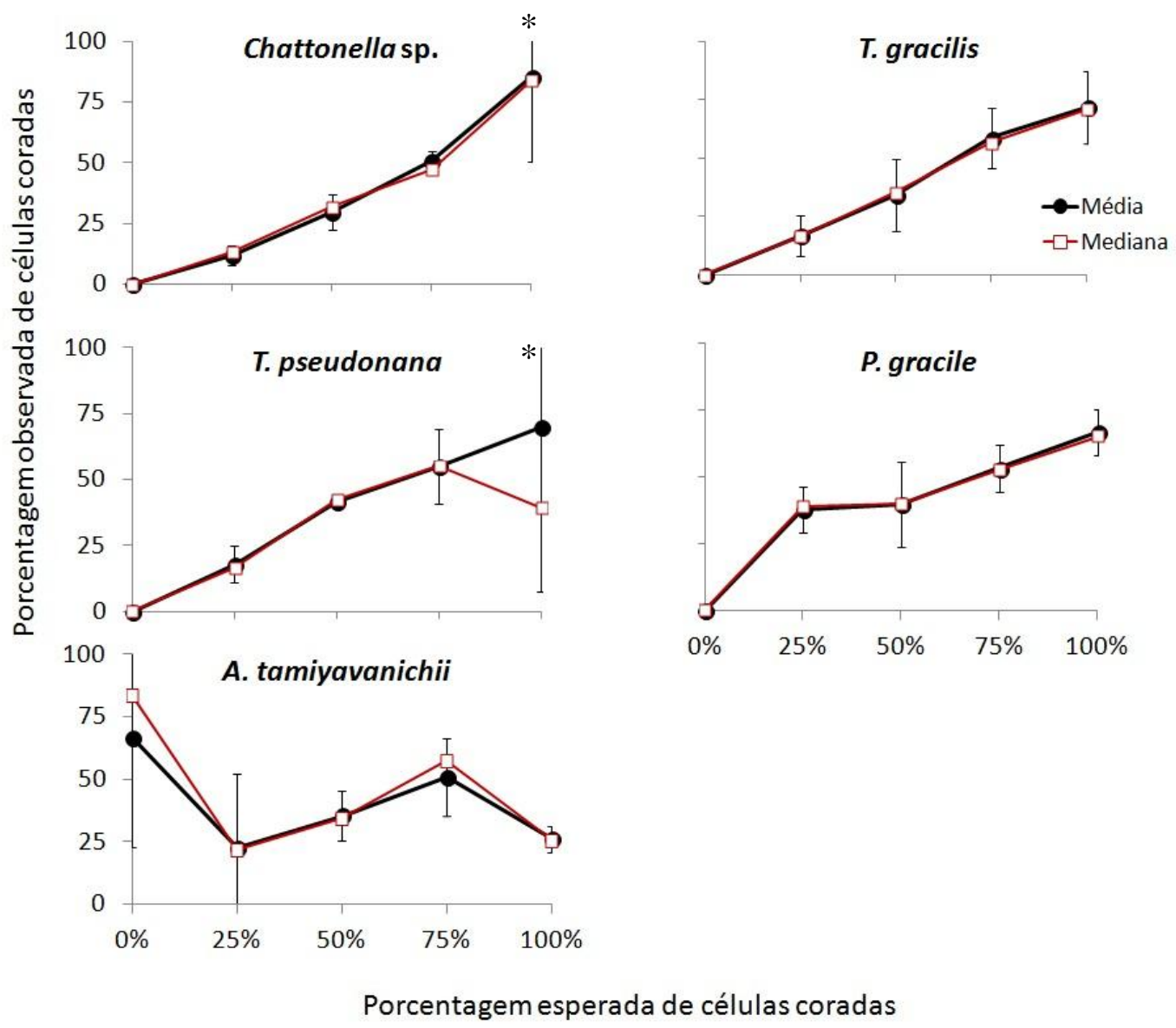

Figura 1.11. Relação entre as médias (preto) observadas de células vivas coradas por CMFDA e a porcentagem esperada por espécie testada. Em vermelho, estão representadas as medianas de cada conjunto de réplicas. As barras verticais representam o desvio padrão. $\mathrm{O} *$ indica que o desvio padrão ultrapassou a área do gráfico representada. 


\section{Padrão de coloração}

A seguir, imagens das células de cada espécie coradas pelo CMFDA.

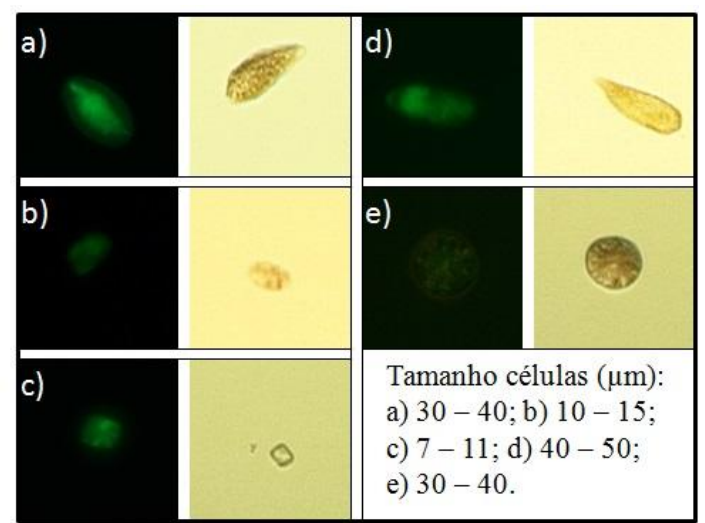

Figura 1.12. Imagens das células coradas pelo CMFDA (vivas $-1^{a}$ coluna, fundo preto) e não coradas (mortas $-2^{\mathrm{a}}$ coluna). Em a) Chattonella sp.; b) T. gracilis; c) T. pseudonana; d) $P$. gracile e, e) A. tamiyavanichii.

\section{Corantes mortais}

\subsubsection{Azul de Evans}

Com exceção de $T$. gracilis, todas as espécies testadas tiveram afinidade com o corante mortal azul de Evans, em um tempo de coloração relativamente rápido.

\section{Tempo de coloração}

Na figura 1.13 é possível observar que a partir de 20 minutos de coloração, tanto para Chattonella sp. como para T. pseudonana, as amostras mantiveram a porcentagem por volta de $100 \%$ de células coradas, como o esperado. No entanto, o melhor contraste do azul nas células coradas para 1,5 uL do corante foi observado a partir dos 40 minutos.

Os dinoflagelados $P$. gracile e A. tamiyavanichii tiveram pouca afinidade com o corante, com porcentagens de células coradas muito abaixo do esperado de $100 \%$. Prorocentrum gracile ainda teve um pico aos 70 minutos de média aproximada de $80 \%$ de células coradas (Fig. 1.13). Apesar disso, o tempo de coloração usado para os primeiros testes foi de 40 minutos. Na segunda repetição dos testes, a fim de melhorar o 
contraste de coloração, foi usado o volume de $3,5 \mu \mathrm{L}$ do corante para $1 \mathrm{~mL}$ de amostra, o qual apresentou bons resultados de contraste após 20 minutos de ação.

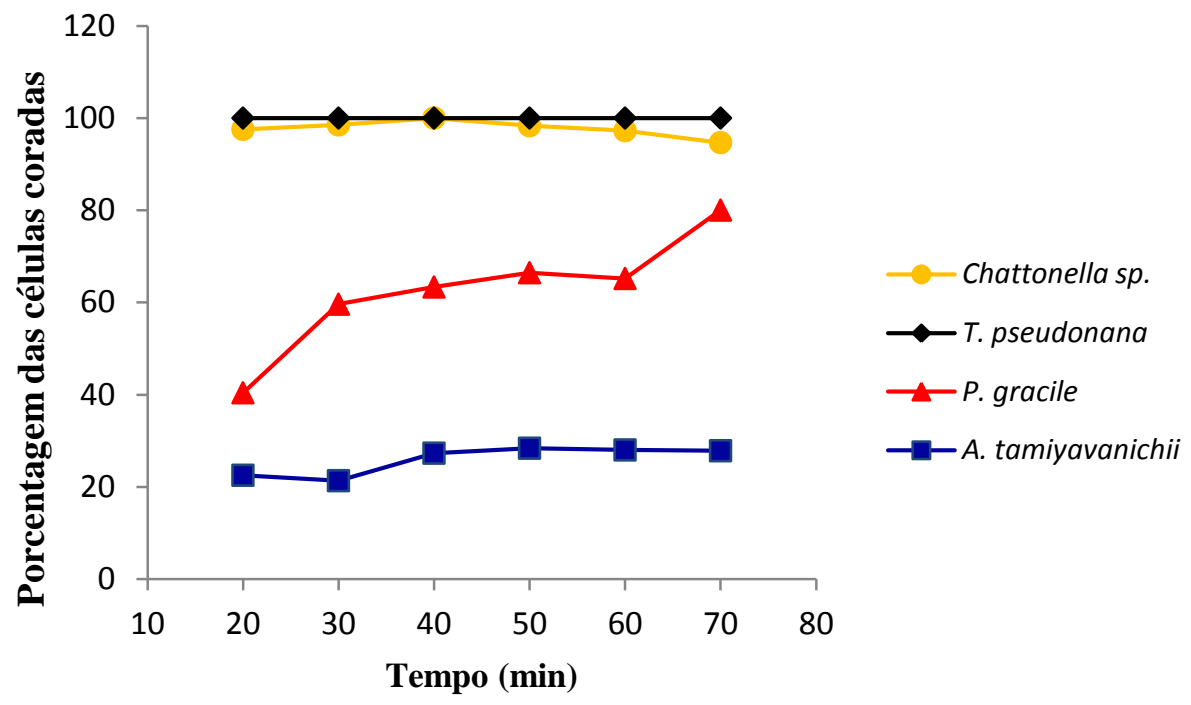

Figura 1.13. Comparação entre os tempos de coloração do corante mortal azul de Evans e a média das porcentagens de células coradas entre as diferentes espécies testadas.

\section{Eficácia}

O corante mortal azul de Evans teve afinidade com as espécies Chattonella sp., T. pseudonana e A. tamiyavanichii, embora para este último a porcentagem esperada de 100\% de células coradas foi de aproximadamente 70\% (Fig. 1.14).

A espécie $P$. gracile teve resultados próximos do esperado para os tratamentos de 0,25 e $75 \%$ (Fig. 1,14). As outras porcentagens desviaram do esperado e as medianas confirmam que as réplicas tiveram resultados homogêneos, ou seja, este desvio não foi efeito de nenhum outlier.

Os desvios padrão de A. tamiyavanichii mostram que houve maior variação entre as réplicas e, por isso, as medianas tenderam para resultados um pouco abaixo do esperado. Apesar disso, de modo geral, os resultados foram satisfatórios para esta espécie. 
O interessante destes resultados foi que para ambos os dinoflagelados não houve coloração total das células para o tratamento de $100 \%$ de células mortas por aquecimento (Fig. 1.14).

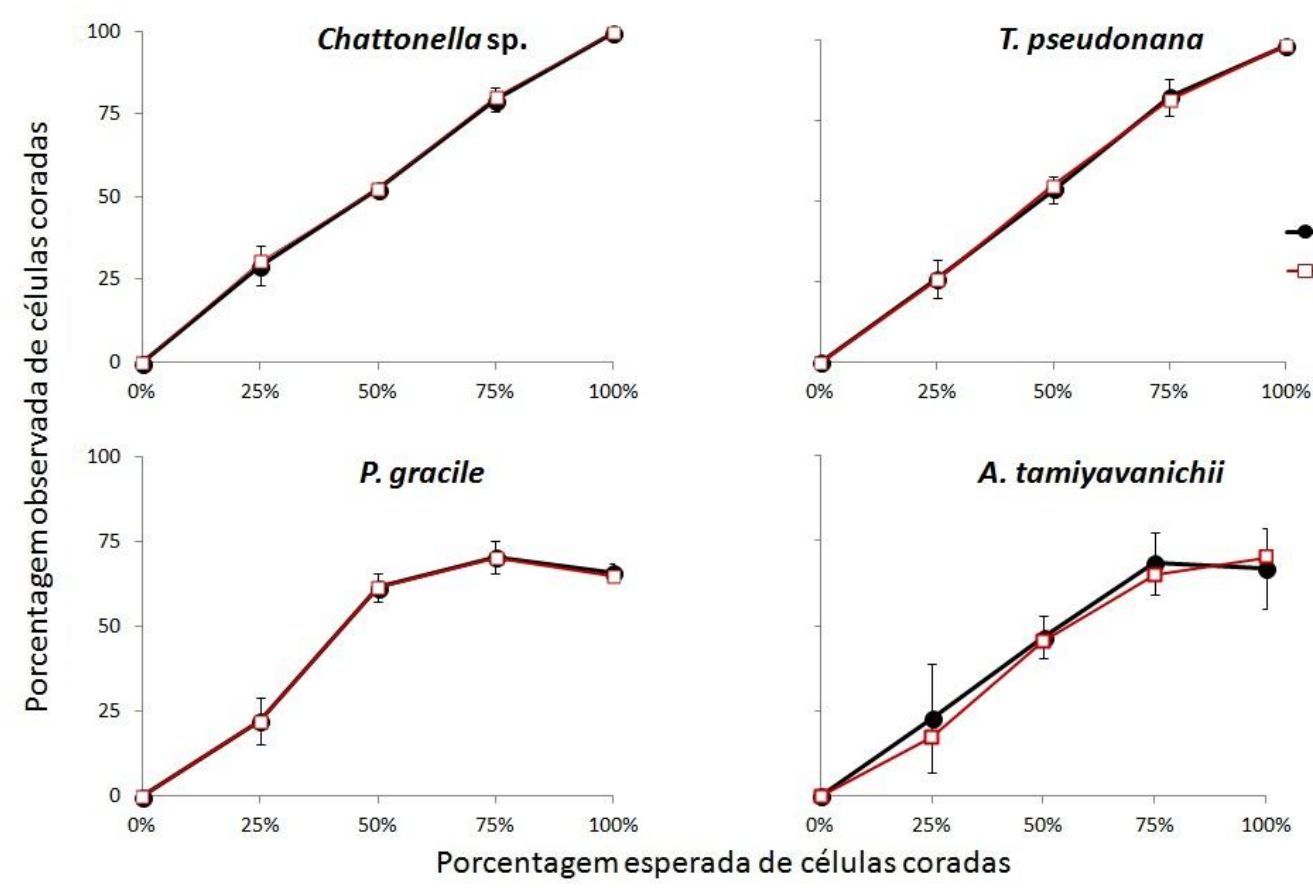

Figura 1.14. Relação entre as médias (preto) observadas de células mortas coradas por azul de Evans e a porcentagem esperada por espécie testada. Em vermelho, estão representadas as medianas de cada conjunto de réplicas. As barras verticais representam o desvio padrão.

\section{Padrão de coloração}

O corante azul de Evans, por não ser fluorescente, também gerou muitas dúvidas em relação ao que seria considerado corado e não corado entre as diferentes espécies. A seguir, exemplos de colorações que foram usadas como padrão para a classificação de células vivas (não coradas) e mortas (coradas). 


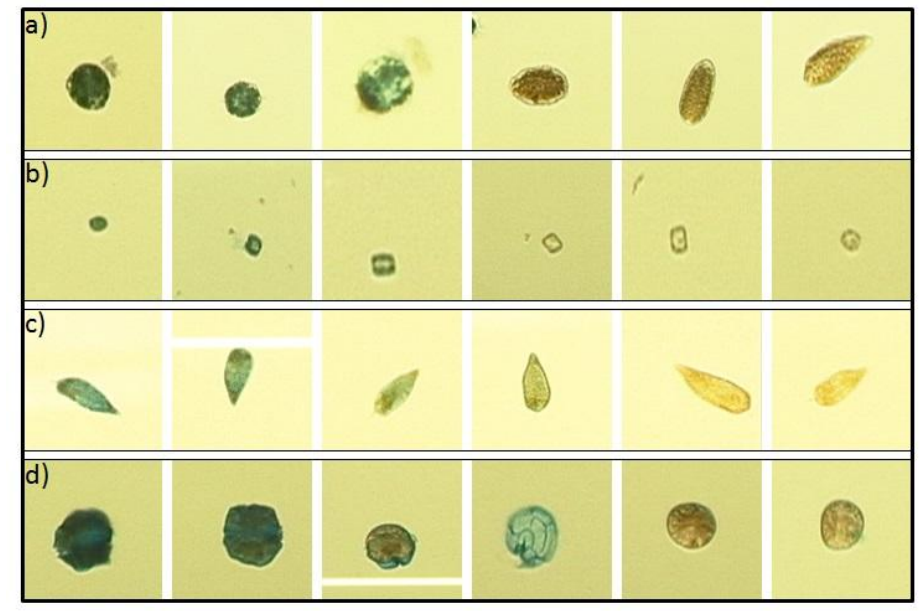

Figura 1.15. Padrão de coloração usado para distinguir células coradas e não coradas com o corante azul de Evans. Em a) Chattonella sp e b) T. pseudonana, até a $3^{\mathrm{a}}$ imagem: células coradas; c) $P$. gracile, até $4^{\mathrm{a}}$ imagem foram consideradas coradas, apesar da $4^{\mathrm{a}}$ gerar muita dúvida, dependendo do padrão de luz do computador; d) A. tamiyavanichii, até $3^{\mathrm{a}}$ imagem: células coradas, na $4^{\text {a }}$ : teca corada, mas não foi considerada célula morta, excluímos da contagem.

\subsubsection{SYTOX Green}

O corante SYTOX Green teve afinidade com todas as espécies testadas. No entanto, devido a problemas de manipulação dos experimentos, falta de experiência ou de equipamento especializado para detectar o sinal, principalmente das células menores, os resultados dos testes não foram adequados como o esperado. Tanto para T. gracilis como T. pseudonana foi impossível fazer a contagem pelo microscópio de epifluorescência.

A espécie Chattonella sp. teve resultados satisfatórios para as porcentagens acima de $25 \%$, apesar de serem abaixo do esperado. Entretanto, houve grande desvio padrão entre as réplicas, o que pode ser comprovado pela linha da mediana, e no tratamento de $0 \%$ de células mortas, que teve aproximadamente $60 \%$ de células coradas (Fig. 1.16).

De modo geral, os dinoflagelados tiveram resultados coerentes, principalmente para o tratamento de $100 \%$ de células mortas, isso mostra a eficiência do corante mortal em marcar células mortas. Apesar disso, houve grande diferença para os tratamentos de 25 e $75 \%$ e altos desvios padrão. 


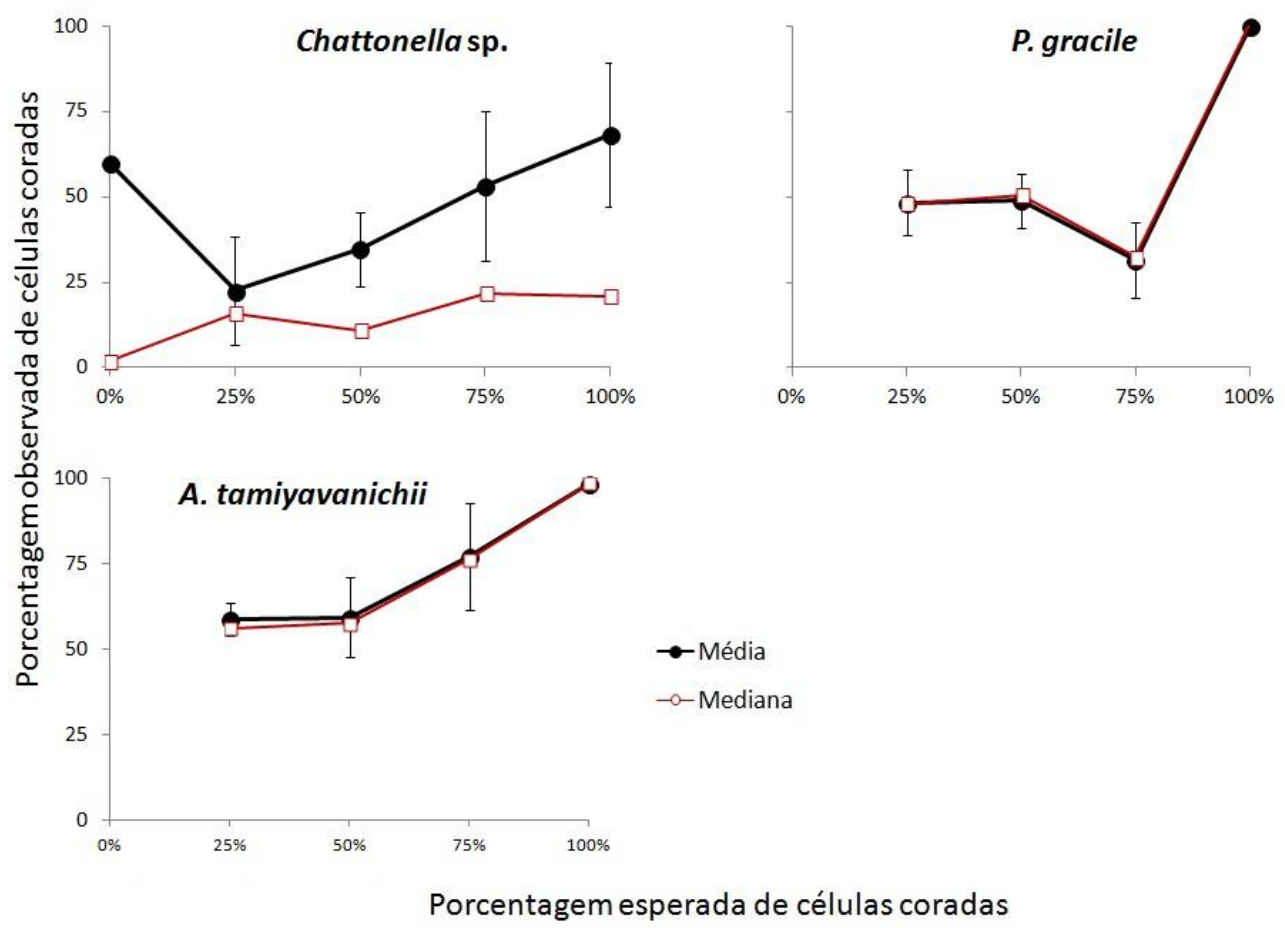

Figura 1.16. Relação entre as médias (preto) observadas de células mortas coradas por SYTOX Green e a porcentagem esperada por espécie testada. Em vermelho, estão representadas as medianas de cada conjunto de réplicas. As barras verticais representam o desvio padrão. Não foram feitos testes com os dinoflagelados no tratamento de $0 \%$ de células mortas, devido ao pouco volume do corante disponível para o experimento.

\section{Padrão de coloração}

Na figura 1.17, estão as imagens das células mortas coradas por SYTOX Green de todas as espécies testadas, para comprovar a afinidade do corante, apesar de não ter sido possível a contagem das espécies $T$. gracilis e $T$. pseudonana. 


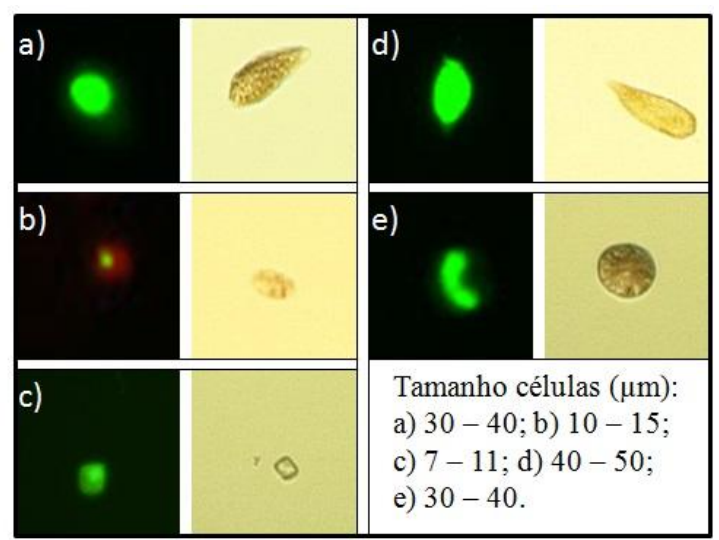

Figura 1.17. Imagens das células coradas pelo SYTOX Green (mortas $-1^{\mathrm{a}}$ coluna, fundo preto) e não coradas (vivas $-2^{\mathrm{a}}$ coluna). Em a) Chattonella sp.; b) T. gracilis (autofluorescência + SYTOX Green); c) T.pseudonana; d) P. gracile e, e) A. tamiyavanichii.

\subsubsection{Azul de tripan (Trypan blue)}

Este corante mortal não teve afinidade em corar as células cultivadas em meio de cultura. Tratamentos de indução à morte celular, como aumento de temperatura e aplicação de formol, não resultaram em coloração das células mortas, somente da matéria orgânica contida no meio. Foram testados volumes de 1,0 a $300 \mu \mathrm{L}$ para cada 1 $\mathrm{mL}$ de amostra e o único resultado satisfatório foi com o dinoflagelado $A$. tamiyavanichii com 3,0 $\mu \mathrm{L}$ do corante em 20 minutos. Porém, a solução ficou bastante azulada, dificultando a observação. Outro teste feito com Chattonella sp., mortas por aquecimento, apresentou início de coloração após 55 minutos. Entretanto, tais testes foram feitos de maneira exploratória para a tomada de decisões dos experimentos. Como foi um corante que exigiu muito tempo de padronização e raramente apresentou resultados satisfatórios, ele não foi usado para os experimentos efetivos deste trabalho.

\subsubsection{Combinação vermelho neutro + azul de Evans}

A combinação entre os corantes não fluorescentes vermelho neutro (vital) e azul de Evans (mortal) resultou em uma solução roxa, com alguns precipitados e coloração de detritos, não permitindo distinguir as células vivas (vermelho) das mortas (azul) (Fig. 1.18). 


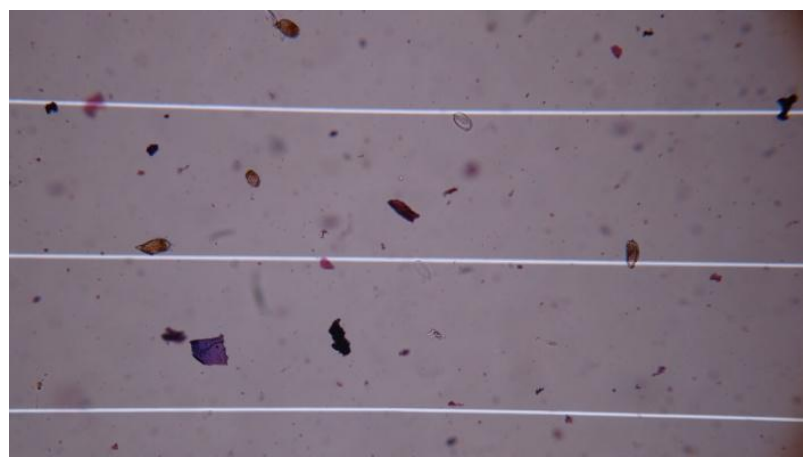

Figura 1.18. Análise em câmara Nageotte de uma alíquota contendo ambos os corantes, adicionados a $1 \mathrm{~mL}$ de cultura de $P$. gracile. Observa-se grande quantidade de detritos corados.

Nos testes de combinação, foram usados como controle os tratamentos com o uso individual dos corantes vermelho neutro e azul de Evans. Como foram feitos com a cultura na fase exponencial, no teste com o vermelho neutro, a maioria das células coraram, e no teste com o azul de Evans, a maioria das células não coraram, como o esperado (Fig. 1.19).

No tratamento da combinação dos corantes com a cultura na fase exponencial, houve um predomínio do corante vermelho neutro, o qual apresentou uma coloração vermelho-escuro. As células mortas não coraram com o azul. Entretanto, como a cultura estava em condições metabólicas ideais, era esperado que houvesse mais células vivas (Fig. 1.19).

No tratamento de combinação dos corantes, em que a cultura tinha metade do volume de células mortas por aquecimento, o esperado era $50 \%$ de células coradas por vermelho neutro e $50 \%$ das células coradas por azul de Evans. Entretanto, somente as células vivas foram coradas, o que pode inferir que o vermelho neutro inibiu a ação do azul de Evans. As células não coradas foram consideradas mortas (Fig. 1.19).

Apesar disso, os resultados mostraram coerência com o esperado, de forma que a combinação não afetou na porcentagem esperada de células vivas coradas. 


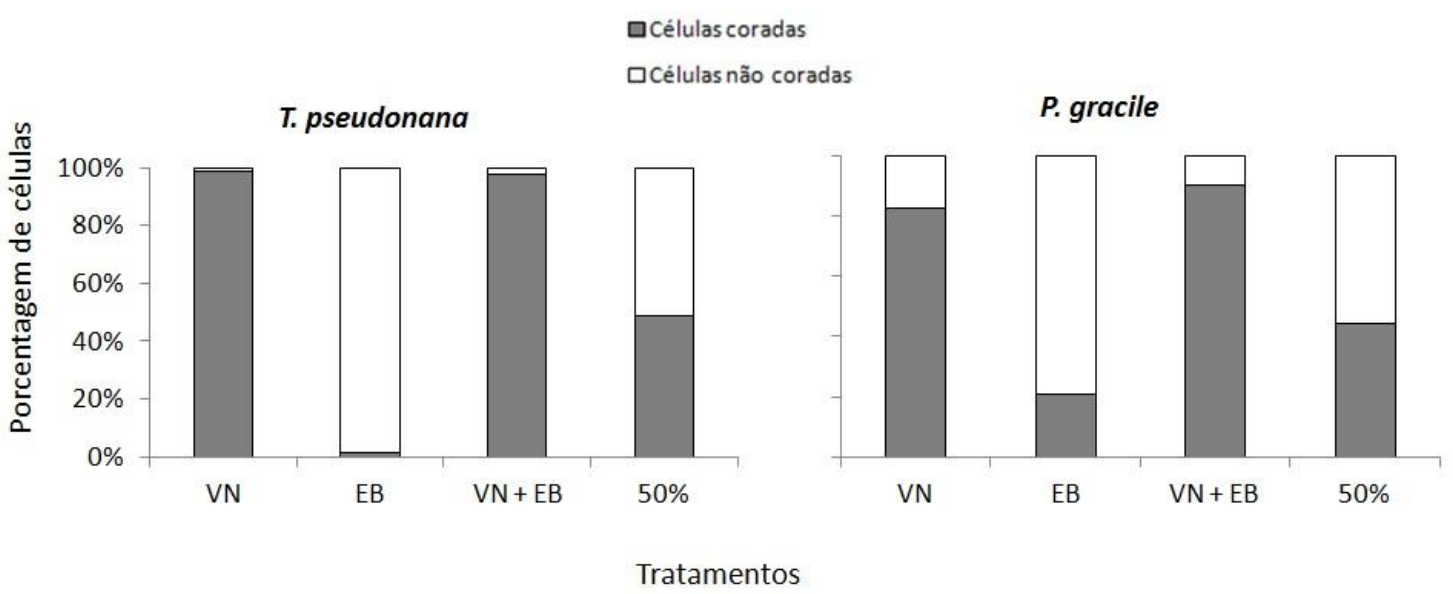

Figura 1.19. Porcentagem do número de células coradas e não coradas nos diversos tratamentos: VN: vermelho neutro individual em cultura na fase exponencial; EB: azul de Evans individual em cultura na fase exponencial; VN + EB: combinação entre vermelho neutro e azul de Evans em cultura na fase exponencial; 50\%: combinação entre vermelho neutro e azul de Evans em 50\% do volume de cultura na fase exponencial e 50\% do volume da cultura morta por aquecimento. Do lado esquerdo, resultados com a espécie $T$. pseudonana, e do direito, a espécie P. gracile.

\subsubsection{Resultados gerais dos corantes}

Todos os corantes testados, com exceção do azul de tripan, mostraram ter afinidade para indicar a viabilidade de células do fitoplâncton marinho. Apesar de atingirem somente quatro das cinco espécies testadas, vermelho neutro e azul de Evans tem grande potencial de uso, pois além de terem sido eficazes em todos os tratamentos de diferentes proporções de células vivas e mortas, são marcadores rápidos e baratos.

A única desvantagem do uso destes corantes em relação aos fluorescentes é o padrão de coloração, já que dependendo da espécie a cor não fica muito evidente, gerando dúvidas na classificação.

Dentre os corantes fluorescentes, o CMFDA teve resultados bastante satisfatórios, com exceção da espécie A. tamiyavanichii. A vantagem do uso deste corante é o forte sinal da fluorescência para distinguir as células vivas das mortas. Entretanto, é um corante mais caro e são necessários equipamentos especializados para a visualização deste marcador.

$\mathrm{Na}$ figura 1.20, há a relação de porcentagem observada de células coradas versus o esperado de todas as espécies testadas por corante. Nestes gráficos é possível 
visualizar o melhor desempenho dos corantes vermelho neutro, azul de Evans e CMFDA.

Além disso, é possível notar a pequena afinidade da espécie $A$. tamiyavanichii para todos os corantes, com exceção do SYTOX Green. Além de apresentar porcentagens abaixo do esperado, a espécie teve os maiores desvios padrão, muitas vezes com valores contrários do esperado.

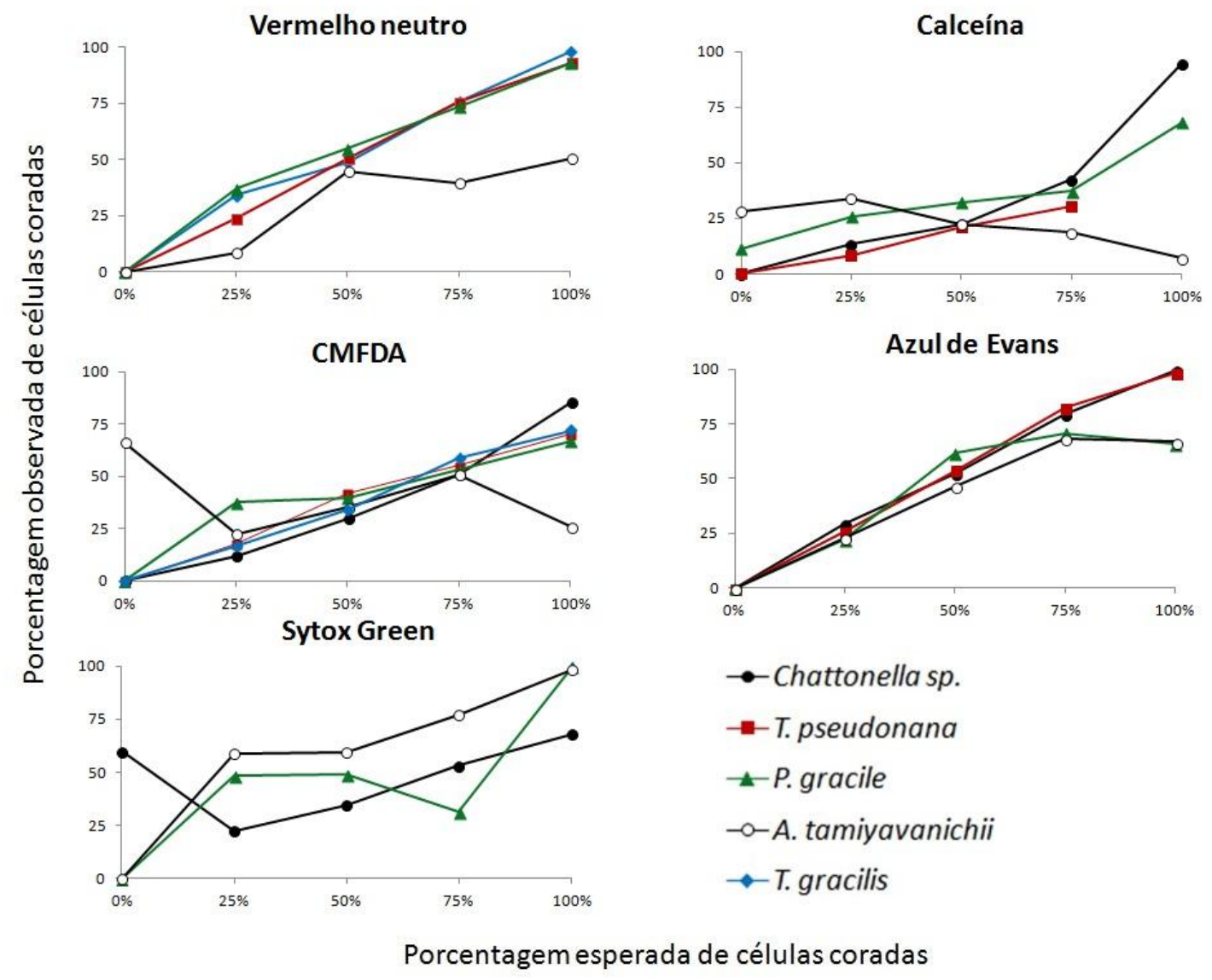

Figura 1.20. Resumo por corante das relações entre as médias da porcentagem de células coradas observadas pelo esperado de cada espécie. Corantes vitais: vermelho neutro, calceína e CMFDA, \% células vivas. Corantes mortais: azul de Evans e SYTOX Green, \% células mortas. Nesta figura não há a indicação da variação de cada média, pois já foi indicado individualmente nas seções anteriores. 


\subsubsection{Métodos de análise}

\section{Observação direta $x$ captura de imagem por filmagem}

Para ambos os corantes, vermelho neutro e azul de Evans, a relação linear entre as contagens dos métodos da filmagem e observação direta foi positiva. A maioria das contagens foi praticamente sobreposta, apenas em alguns casos, principalmente com os dinoflagelados, houve maior diferença nas contagens (Figs. 1.21 e 1.22).

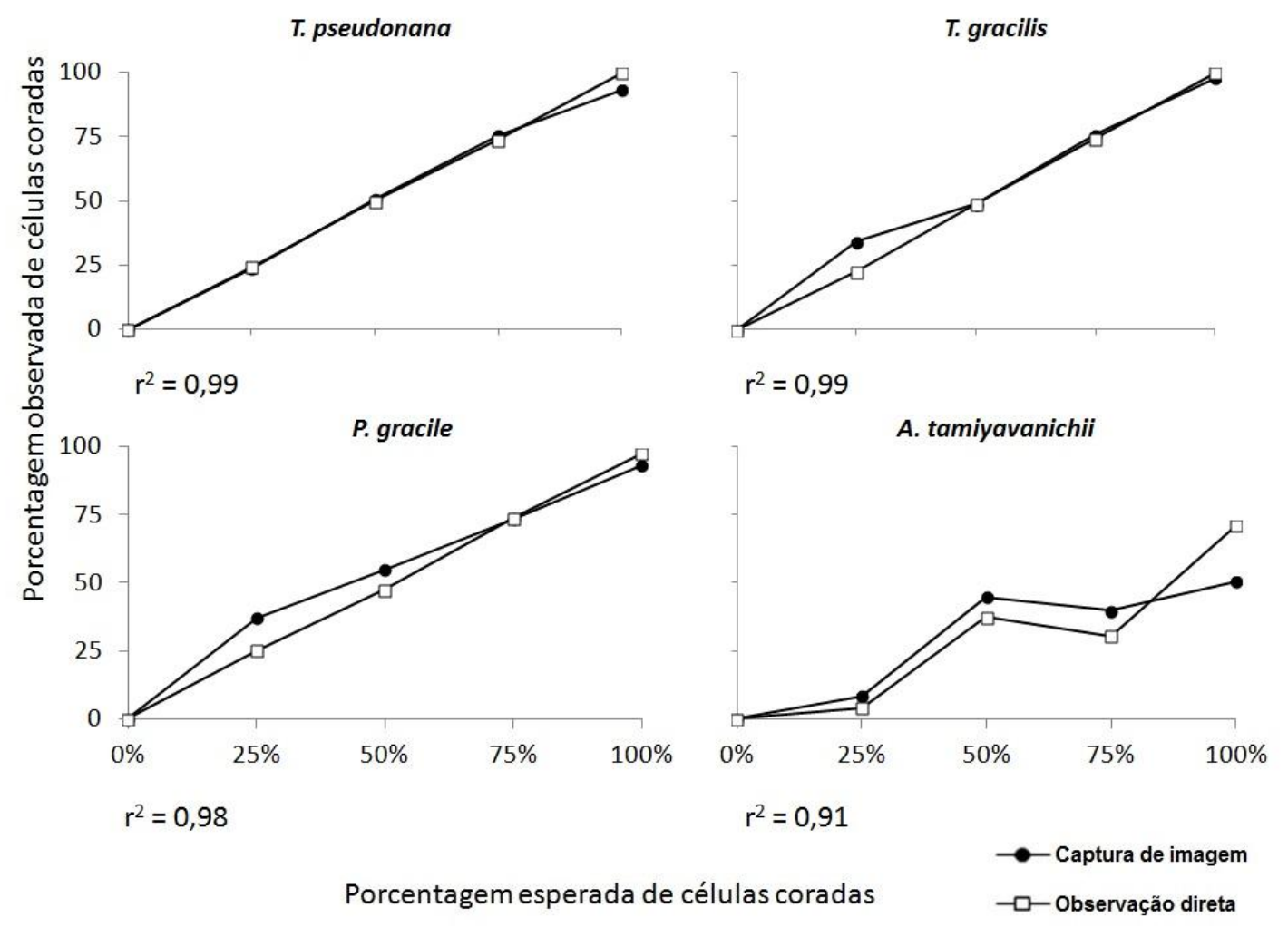

Figura 1.21. Correlação entre a porcentagem observada de células coradas pelo vermelho neutro e o esperado, das contagens feitas pelos métodos de observação direta (quadrado) e captura de imagem por filmagem (círculo). Abaixo de cada gráfico está representado o coeficiente de correlação. 
T. pseudonana

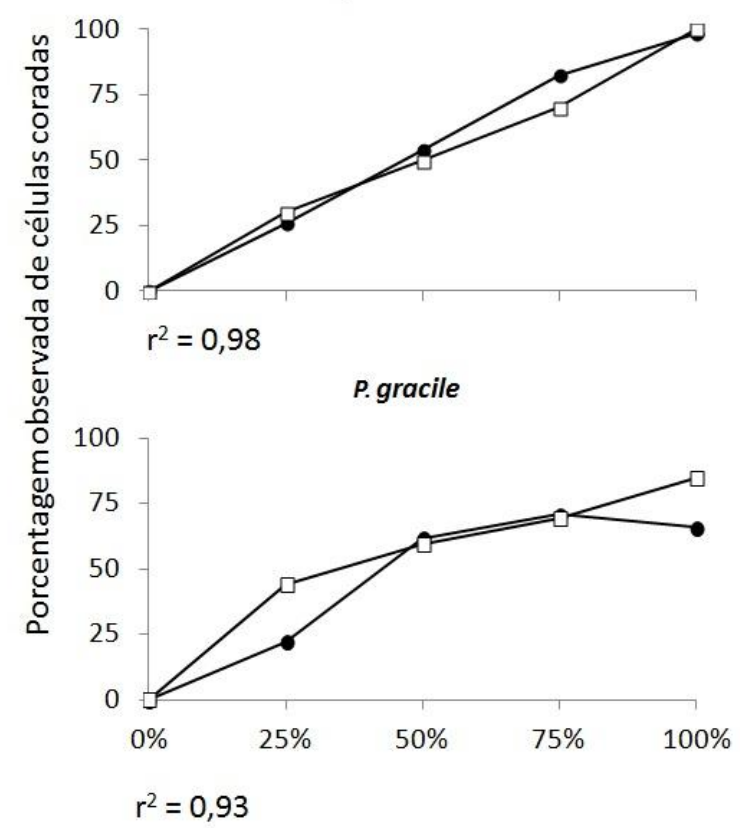

Chattonella sp.

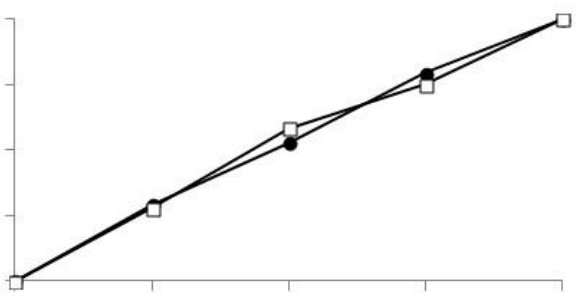

$r^{2}=0,99$

A. tamiyavanichii

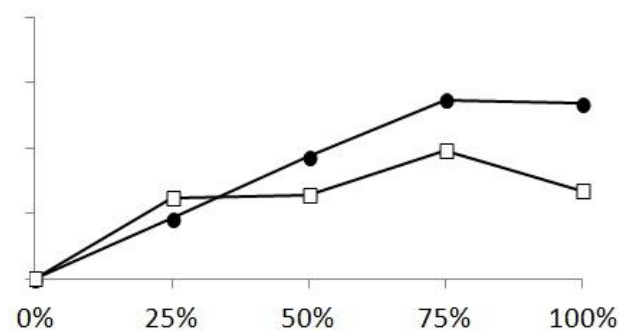

$r^{2}=0,87$

Porcentagem esperada de células coradas

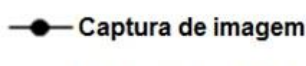

$\rightarrow-$ Observação direta

Figura 1.22. Correlação entre a porcentagem observada de células coradas pelo azul de Evans e o esperado, das contagens feitas pelos métodos de observação direta (quadrado) e captura de imagem por filmagem (círculo). Abaixo de cada gráfico está representado o coeficiente de correlação.

Apesar disso, vale ressaltar que é uma comparação indireta, pois não são as mesmas amostras que foram contadas nos diferentes métodos. Além disso, as diferenças também podem estar relacionadas com o próprio comportamento da espécie com o corante e não somente pela ineficiência dos métodos.

Entretanto, de modo geral, os resultados foram positivos, o que infere a possível substituição do método tradicional de contagem manual na microscopia (mais moroso) pela filmagem, o qual apesar de também ser manual, é mais rápido e permite salvar as imagens, para contagem posterior. 


\section{Observação direta X FlowCAM}

De modo geral, a contagem através das imagens capturadas pela FlowCAM, quando comparada com a feita pela observação direta no microscópio, foi bastante similar para todas as proporções de células vivas e mortas, com alta correlação linear entre os métodos $\left(r^{2}>0,98\right)$. Não houve diferenças significativas entre os corantes vermelho neutro (Fig. 1.23) e azul de Evans, apesar deste último ter tido porcentagens superestimadas pela FlowCAM (Fig. 1.24).

Mesmo assim, ambos os corantes tiveram resultados satisfatórios e foram fáceis de analisar na FlowCAM.

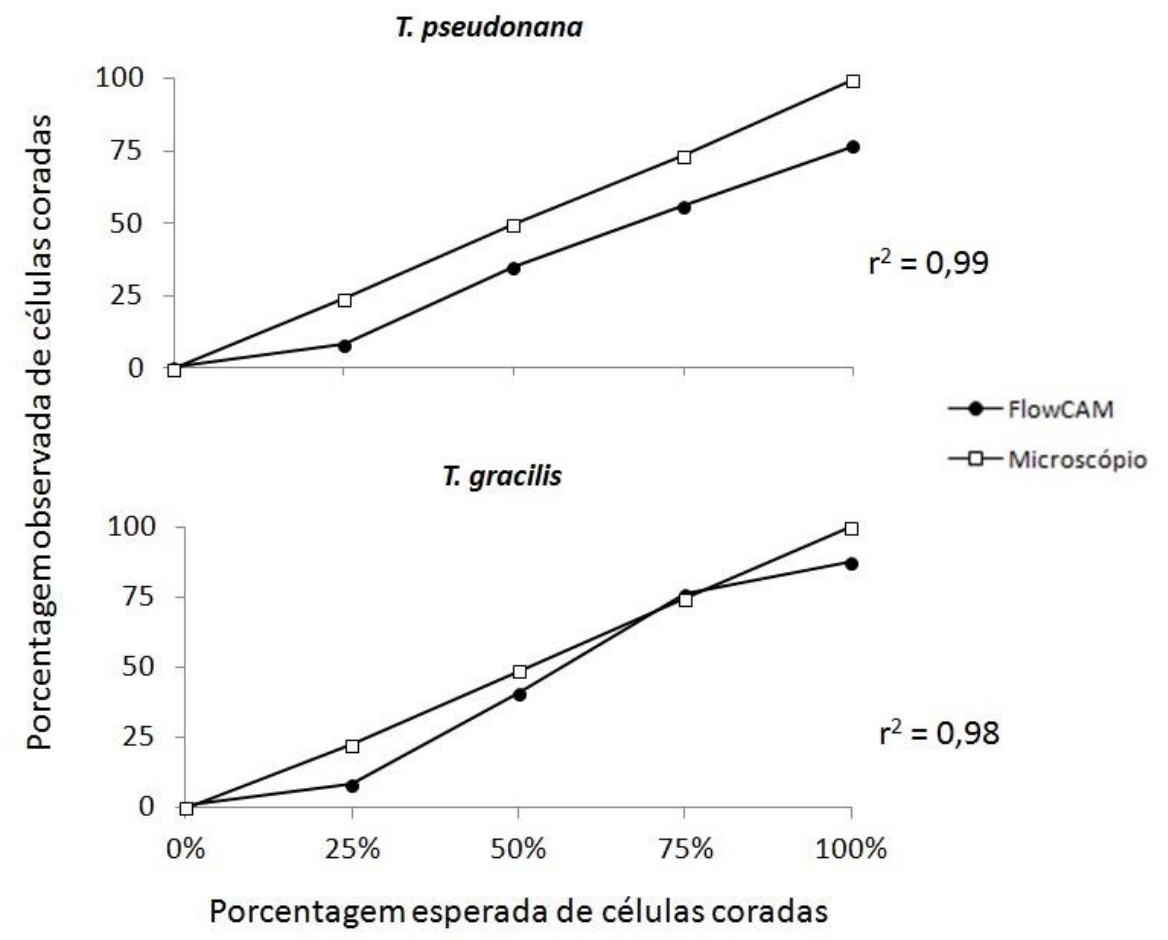

Figura 1.23. Correlação entre a porcentagem observada de células coradas pelo vermelho neutro e o esperado, das contagens feitas pelos métodos de observação direta (quadrado) e captura de imagem pela FlowCAM (círculo). 


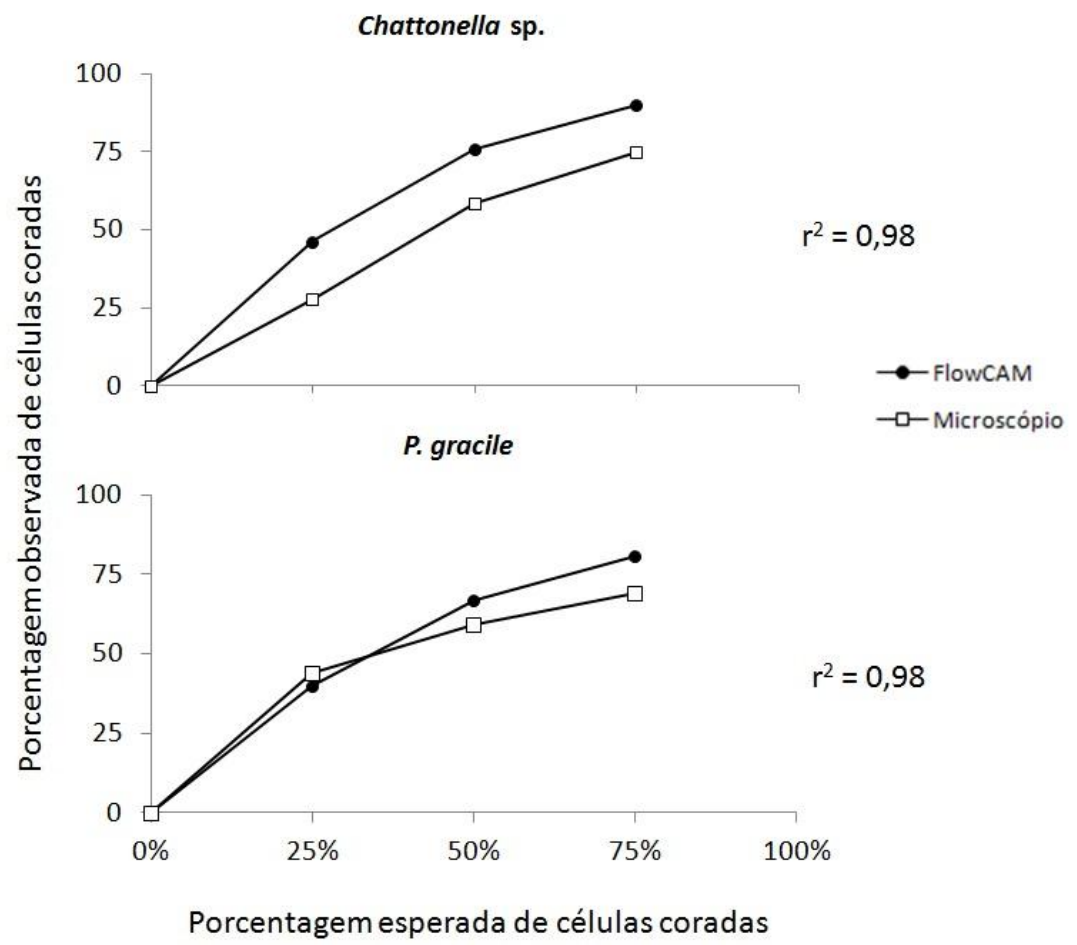

Figura 1.24. Correlação entre a porcentagem observada de células coradas pelo azul de Evans e o esperado, das contagens feitas pelos métodos de observação direta (quadrado) e captura de imagem pela FlowCAM (círculo).

Abaixo seguem algumas imagens obtidas pela FlowCAM das diferentes espécies analisadas, mostrando a facilidade de classificar células coradas e não coradas, apesar de algumas imagens não terem foco.

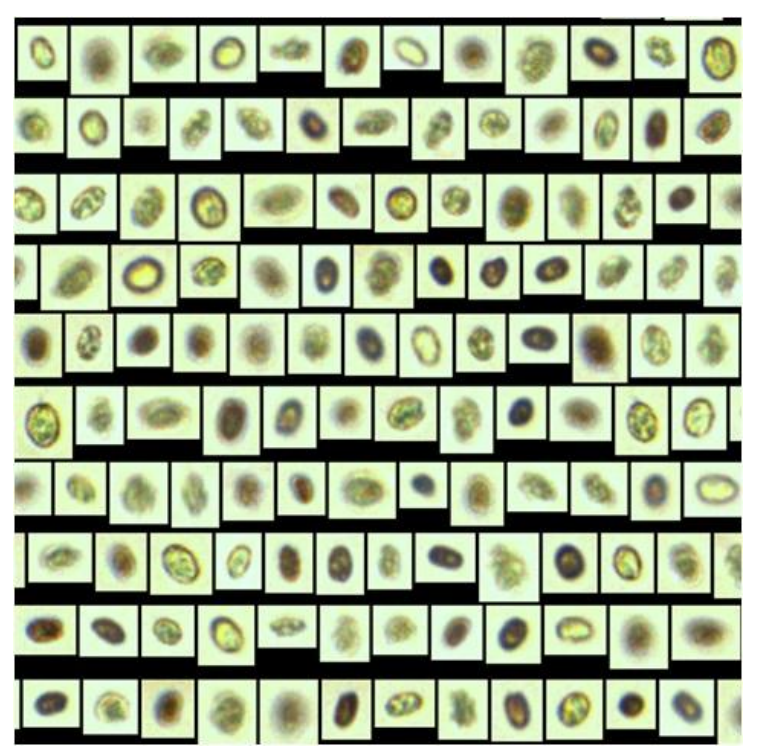

Figura 1.25. Imagens capturadas pela FlowCAM da espécie $T$. gracilis com o vermelho neutro. Note que há células que ficaram sem foco, mas mesmo assim é possível identificar a coloração. 


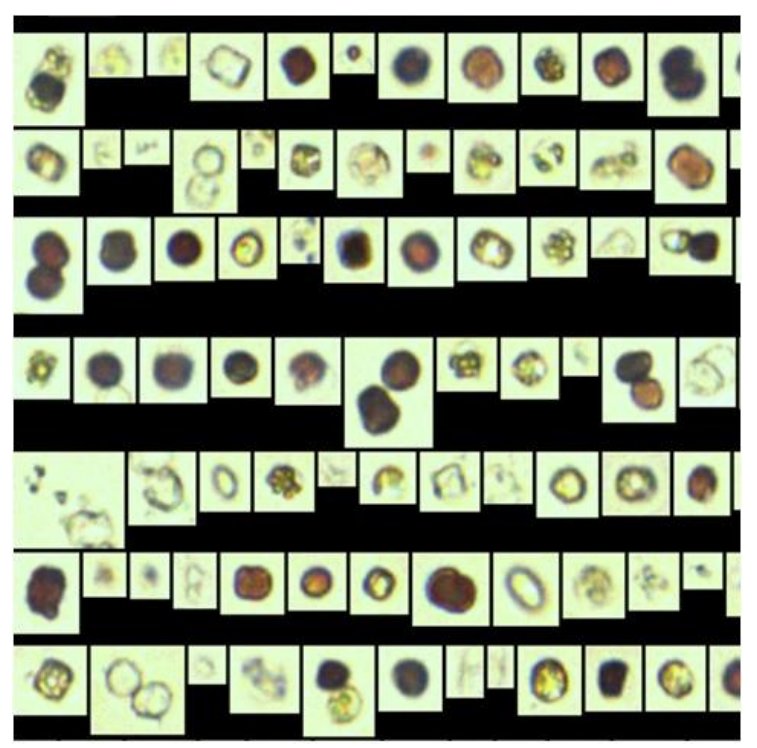

Figura 1.26. Imagens capturadas pela FlowCAM da espécie T. pseudonana com o vermelho neutro. Note que há vinhetas com mais de uma célula. Neste caso, foi feita uma biblioteca somente para estas imagens, para dobrar a contagem. Os detritos foram descartados da contagem.

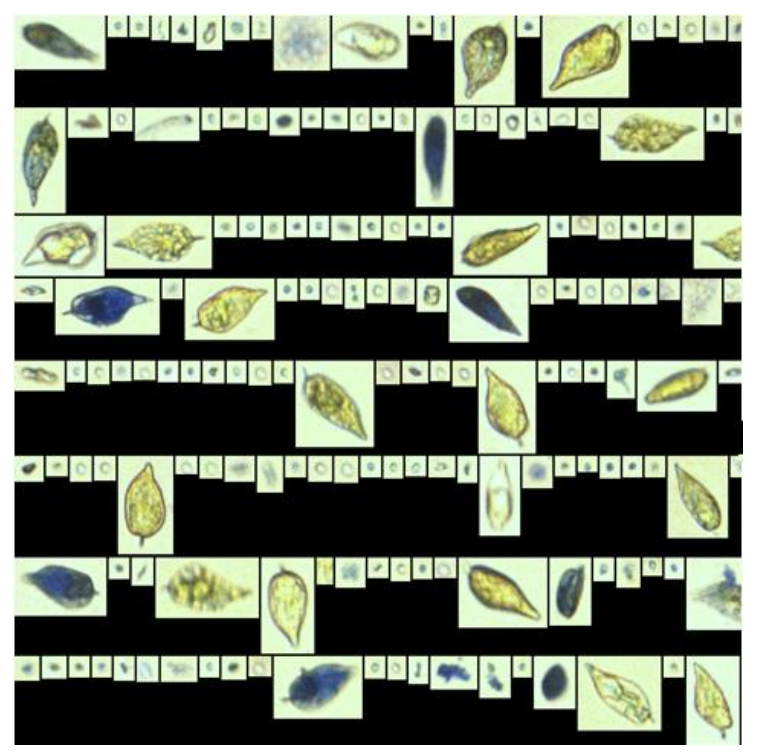

Figura 1.27. Imagens capturadas pela FlowCAM da espécie $P$. gracile com o azul de Evans. Note a presença de detritos, os quais foram descartados da contagem. 


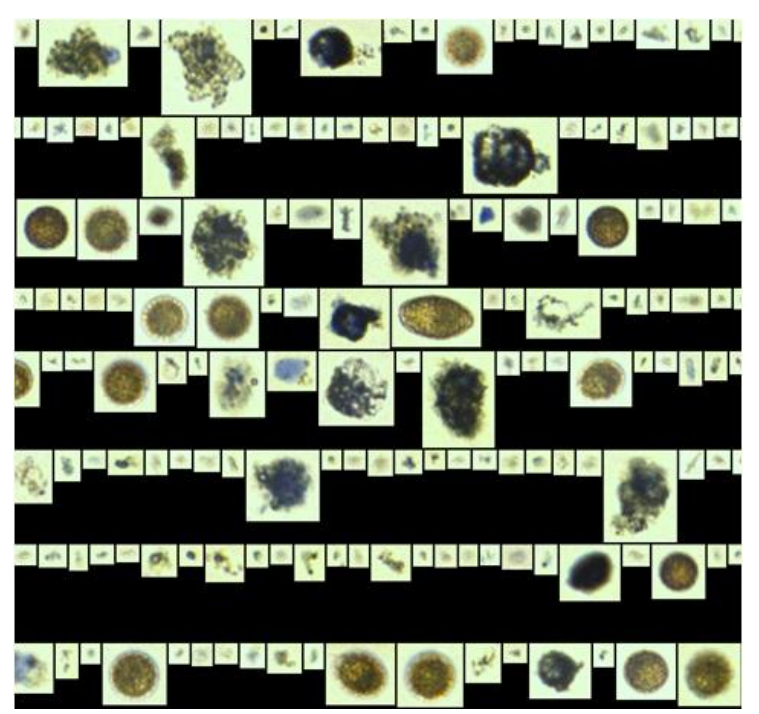

Figura 1.28. Imagens capturadas pela FlowCAM da espécie Chattonella sp. com o azul de Evans. Note que há tanto células intactas como células que sofreram lise celular que foram coradas pelo azul de Evans. Ambos os casos foram contados como células coradas. Os detritos foram descartados da contagem.

\subsection{Discussão}

\subsubsection{Corantes vitais}

Dentre os corantes vitais, o vermelho neutro (VN) e o CMFDA tiveram os melhores resultados em relação ao esperado. O vermelho neutro é considerado um corante praticamente universal para identificar organismos planctônicos viáveis (Elliott \& Tang, 2009; Zetsche \& Meysman, 2012), apesar de ser ainda pouco utilizado em fitoplâncton devido ao efeito tóxico nas células (Carney, 2011).

O vermelho neutro tem rápida ação, foi eficiente para todos os métodos de observação testados e teve afinidade com a maioria das espécies estudadas, com exceção da Chattonella sp. e A. tamiyavanichii, para as quais inferimos que causou um efeito tóxico ou lixiviação do corante. Estes efeitos já foram comentados por outros autores (Crippen \& Perrier, 1974; Reynolds et al., 1978; Onji et al., 2000). Reynolds et al. (1978) observaram que o VN não foi incorporado nas células de Skeletonema costatum provavelmente por uma lixiviação minutos após a adição do mesmo, o que pode ter ocorrido com A. tamiyavanichii que teve seu pico de coloração aos 10 minutos de ação do corante e após este tempo houve diminuição de células coradas. Apesar 
disso, Onji et al. (2000) conseguiram corar este mesmo gênero com o VN após 20 minutos de ação.

Reynolds et al. (1978) tentaram re-inocular as espécies que receberam o VN e não observaram crescimento celular, inferindo o efeito tóxico do corante. Ou seja, as amostras com VN devem ser rapidamente analisadas para a determinação de células vivas e mortas, ou preservadas em baixas temperaturas ou com formol para posterior análise (Reynolds et al., 1978; Elliot \& Tang, 2009; Carney, 2011).

Outros efeitos observados, após a adição do corante, foram a imobilização das células que possuem cílios ou flagelos, e mudanças morfológicas, como células ovais ficarem com formatos arredondados (Crippen \& Perrier, 1974; Reynolds et al., 1978), como foi o caso da Chattonella sp. antes de sofrer lise.

O padrão de coloração do VN é um fator determinante para sua aplicabilidade. Como foi visto, ele gerou dúvidas para determinar células vivas e mortas para algumas espécies. Entretanto, outros trabalhos sugerem a acidificação da amostra antes da análise para melhorar a distinção de coloração das células. Após a adição do ácido, a amostra fica com coloração rosa e facilita a contagem (Reynolds et al.,1978; Elliot \& Tang, 2009; Carney, 2011). Este procedimento foi feito em testes preliminares, mas como não percebemos diferenças significativas, não foi utilizado neste trabalho.

Apesar destas implicações, o VN é um corante de potencial aplicação no monitoramento ambiental, principalmente por ser rápido, barato e apropriado para qualquer equipamento de análise. Ao contrário dos corantes fluorescentes calceína e CMFDA, que são caros e dependem de um microscópio epifluorescente ou de um citômetro de fluxo para análise.

Os testes feitos com a calceína tiveram grandes desvios padrão, o que pode ser devido à ineficiência do corante ou erro de amostragem e observação. Hernlem \& Hua (2010) encontraram correlação positiva entre o número de células viáveis de bactérias e o número de células coradas pela calceína, entretanto, não há dados quantitativos para comparação. Peperzak \& Brussaard (2011) testaram a calceína com 40 cepas de fitoplâncton e não obtiveram sucesso com espécies dos gêneros Alexandrium, Prorocentrum e Tetraselmis, as quais também mostraram resultados fora do esperado neste trabalho.

Vale ressaltar que a maioria dos estudos com a calceína são com bactérias, células humanas ou de plantas superiores (Bratosin et al., 2005; Chitarra et al., 2006; 
Hernlem \& Hua, 2010), o que demanda de mais estudos deste corante para células de fitoplâncton.

O mais interessante foi a coloração da fluorescência da calceína em células de dinoflagelados que receberam o tratamento de aquecimento e supostamente estavam mortas (tratamento de $0 \%$ de células vivas). Este fato pode inferir a falta de afinidade do corante para este taxa, a ineficiência do tratamento de morte por aquecimento, ou a formação de esporos e cistos, estado no qual os dinoflagelados se mantém viáveis mesmo em baixas condições de vida ou de stress ambiental. Neste caso, os dinoflagelados em formas de resistência podem ter continuado com a respiração celular, liberando a esterase como subproduto, a qual serve como princípio ativo da calceína. Apesar disso, é preciso estudar mais aprofundadamente a formação de cistos destes grupos e a possibilidade da determinação da viabilidade deste estado de vida, como fez Garvey et al. (2007), que induziu o encistamento e isolou os cistos para corar com o FDA.

O corante CMFDA teve afinidade com todas as espécies testadas, o que demonstra ter grande potencial de uso. Entretanto, as réplicas tiveram grandes desvios padrão, o que pode ter sido devido a um erro de contagem e observação ou a um erro amostral. Steinberg et al. (2011) também fizeram tratamento de aquecimento em protistas marinhos e apesar de não terem observado nenhum movimento das células, houve a detecção da fluorescência, que foram considerados falsos positivos e, por isso, indicaram a formação de cistos. Estes organismos eram pertencentes ao grupo dos dinoflagelados, heterotróficos ou mixotróficos, sendo que um deles também era do gênero Prorocentrum.

Apesar de falsos positivos e negativos, alguns autores sugerem o uso do CMFDA em combinação com o FDA (flurosceína diacetato), para abranger um maior número de espécies (Peperzak \& Brusaard, 2011; Steinberg et al., 2011). Steinberg et al. (2011) também ressaltaram o problema da autofluorescência em verde (Green autofluorescence - GAF) em alguns taxa, como dinoflagelados, diatomáceas e ciliados. Neste caso, é necessário um observador especialista e o uso do citômetro de fluxo, o qual pode diferenciar o sinal verde da autofluorescência e o verde dos corantes, como o FDA, SYTOX Green, entre outros. Esta situação pode ocorrer em espécies resistentes a alguns tratamentos de morte, como o aquecimento ou congelamento. Para evitar 
dúvidas, os autores sugerem o uso de corantes mortais que penetrem nas células mortas com membranas comprometidas.

\subsubsection{Corantes mortais}

Dentre os corantes mortais, o azul de Evans (EB) teve a melhor eficiência para detectar células mortas, principalmente por ficar retido nas células, ao contrário do vital não fluorescente vermelho neutro que para algumas espécies ocorre a lixiviação (Reynolds et al., 1978). Azul de Evans cora rápido, é fácil de manusear, pode ser analisado em diversos equipamentos, inclusive em microscópios de epifluorescência (excitação em $620 \mathrm{~nm}$, emissão em $680 \mathrm{~nm}$ - Saria \& Lundberg, 1983), e teve resultados satisfatórios nos testes de proporções de células vivas e mortas em relação ao esperado.

A única espécie que não teve afinidade com o EB foi a Tetraselmis gracilis, apesar de Carney (2011) ter apresentado resultados satisfatórios com uma espécie do mesmo gênero, T. suecica, morta também por aquecimento. Onji et al. (2000) também não detectaram células mortas através do EB em espécies de Tetraselmis.

Além disso, nos tratamentos de $100 \%$ de células mortas dos dinoflagelados, a maior porcentagem de coloração foi de aproximadamente $66 \%$. Neste caso, uma explicação seria a parcial afinidade do EB para este grupo, ou o tratamento de morte por aquecimento ter sido ineficaz para os dinoflagelados, os quais teriam ficado em formas de resistência na condição de stress ambiental (Gregg et al., 2009).

Entretanto, Onji et al. (2000) demonstraram a eficácia do EB para a espécie Alexandrium catenella, também pertencente ao grupo dos dinoflagelados. E para os gêneros Chattonella e Prorocentrum, os autores não encontraram afinidade com o EB, o contrário visto por este trabalho.

O SYTOX Green (SG) teve afinidade com todas as espécies testadas, como visto na figura 1.17. Porém, não foi possível fazer a contagem das espécies de menor tamanho usando o microscópio epifluorescente. A maioria dos trabalhos que usam o SYTOX Green em células sugere o uso do citômetro de fluxo, com resultados mais precisos (Veldhuis et al. 2001; Binet \& Stauber, 2006; Peperzak \& Brussaard, 2011). Veldhuis et al. (2001) encontraram mais de vinte espécies compatíveis com o corante, dentre elas Tetraselmis sp., Nannochloropsis sp., Amphidinium sp. e Thalassiosira sp. De 40 espécies testadas no trabalho de Peperzak \& Brussaard (2011) somente 10 não 
coraram com o SYTOX Green. Porém, ambos os trabalhos utilizaram a citometria de fluxo.

Somente Sato et al. (2004) utilizou a microscopia de epifluorescência e obteve ótimos resultados de porcentagem de células vivas e mortas em relação ao esperado com o SYTOX Green, porém utilizaram outras espécies, inclusive de cianobactérias, e usaram tratamento de álcool para diminuir a influência da autofluorescência.

Das contagens que foram possíveis de realizar neste trabalho no microscópio, houve grandes desvios padrão, o que pode ter sido devido a erros de manipulação ou ao equipamento inadequado para visualização das células. Porém, não há trabalhos que apresentem dados quantitativos com a mesma divisão de proporções de células vivas e mortas utilizando o citômetro de fluxo, para comparar a eficácia dos métodos.

Apesar de não termos obtidos bons resultados com este corante, ele é recomendado por muitos autores, principalmente pelo fato de ser um marcador de membranas comprometidas (membrane probes), inclusive de cistos de dinoflagelados (A. catenella com concentração de 0,2 uM por 5 minutos) (Binet \& Stauber, 2006).

\subsubsection{Microscopia $X$ filmagem $X$ FlowCAM}

$\mathrm{Na}$ maioria dos trabalhos já realizados sobre o efeito dos corantes sob o fitoplâncton foi utilizada a microscopia direta (Onji et al., 2000; Sato et al., 2004; Garvey et al., 2007; Steinberg et al., 2011; Zetsche \& Meysman, 2012) e a citometria de fluxo, principalmente para os fluorescentes (Binet \& Stauber, 2006; Herlem \& Hua, 2010; Peperzak \& Brusaard, 2011).

A inovação do atual trabalho foi a captura de imagens feita pela filmagem através do microscópio, que permitiu a contagem pelos quadros extraídos, a qual foi comparada com a contagem através da observação direta. A relação positiva entre os métodos permite a substituição da observação direta no microscópio pela filmagem, método mais rápido de análise. Contudo, ainda há aspectos para padronizar os vídeos, como, por exemplo, a luz de fundo. Mas espera-se futuramente a realização da contagem automática pelo programa MatLab, o qual além de extrair os quadros da filmagem, consegue detectar e contar as células coradas e não coradas.

A FlowCAM também vem sido utilizada como um instrumento para contagem e detecção da viabilidade do fitoplâncton, como fez Reavie et al. (2010) e Carney (2011) com corantes fluorescentes no modo Trigger (de fluorescência). Porém, eles não 
descartam o uso da microscopia, método que acreditam ainda ser mais confiável, enquanto não houver uma melhor padronização e estudo sobre o uso da FlowCAM.

O diferencial deste trabalho, foi o uso da FlowCAM com corantes não fluorescentes, vermelho neutro e azul de Evans, no modo AutoImagem. Os resultados obtidos foram muito similares do da microscopia tradicional, o que permite a substituição dos métodos. Entretanto, também recomendamos mais estudos com a FlowCAM e seu software para deixar mais eficiente e confiável as contagens. Apesar disso, vimos que a simples separação de células coradas e não coradas por bibliotecas para a classificação de imagens já facilita a contagem das inúmeras células que são detectadas no fluxo. Uma das vantagens da FlowCAM é poder analisar um volume maior de amostra em um menor tempo.

\subsection{Conclusões}

Para este trabalho, em que foi utilizada a microscopia para observação e análise das células, os corantes que tiveram melhor eficácia foram os vitais vermelho neutro e CMFDA, e o corante mortal azul de Evans.

Tanto para os corantes fluorescentes como para os não fluorescentes, a experiência do observador foi importante para obter resultados mais acurados. Apesar dos trabalhos atuais utilizarem a citometria de fluxo, a literatura mostra poucos estudos quantitativos, principalmente em diferentes proporções de células vivas e mortas, como este trabalho mostrou.

Ainda que sejam técnicas fáceis e rápidas de analisar, não há um protocolo universal de uso, pois os resultados dos corantes podem mudar de acordo com a espécie. Um exemplo são os resultados do azul de Evans quanto ao gênero Tetraselmis, que teve diferentes resultados de coloração em diversos trabalhos, dependendo da espécie. Na tese de Carney (2011) Tetraselmis suecica teve mais de 98\% de coloração, porém tanto no atual trabalho como no de Onji et al. (2000) o azul de Evans não teve afinidade com as espécies deste gênero.

Peperzak \& Brussaard (2011) fizeram análises multivariadas com diferentes corantes e concluíram que há uma relação significativa entre eles e a classe do fitoplâncton. Ou seja, não há ainda um corante universal, pois cada um deles tem um 
tipo de resposta de acordo com a espécie estudada, e por isso o mais indicado é utilizar mais de um corante, mesmo que individualmente, para obter resultados mais acurados.

O uso da filmagem feita pelo microscópio, mesmo não sendo filmada toda a câmara de contagem, é possível para a substituição da contagem mais morosa no microscópio. Além dos resultados de ambos os métodos serem correlacionados, o método da filmagem permite salvar as imagens das células, evitando a contagem instantânea, o que permite fazer mais filmagens no laboratório e mais de um observador poder fazer a contagem e minimizar os erros de padrão de coloração dos corantes não fluorescentes. A contagem automática por programa computacional também é possível, o que viabilizará ainda mais esta técnica.

Para os corantes fluorescentes, a microscopia epifluorescente foi efetiva, mas principalmente para as espécies muito pequenas, a citometria de fluxo pode ser uma melhor opção metodológica. 
CAPÍTULO 2

\title{
Avaliação da eficácia de corantes para detecção da viabilidade do \\ fitoplâncton após tratamento da água de lastro
}

\begin{abstract}
RESUMO
O transporte de organismos pela água de lastro tem sido um dos impactos marinhos mais preocupantes da atualidade. Além de permitir a invasão de espécies exóticas em novos habitats, está prejudicando a ecologia local, saúde humana e atividades socioeconômicas. Para minimizar este problema, a IMO (Organização Internacional Marítima) obrigou os navios a fazerem troca da água de lastro em alto mar, porém, além de ser difícil a fiscalização, não á garantida a eliminação total dos organismos, principalmente os de menores tamanhos, como o fitoplâncton. Desta forma, estão sendo desenvolvidos tratamentos de água para serem implantados nos tanques de lastro, dentre eles físicos, químicos e mecânicos. $\mathrm{O}$ objetivo deste trabalho foi avaliar métodos de validação da eficácia de alguns tratamentos da água de lastro, como a radiação UV, ozônio e o germicida Peraclean, através da coloração vital e mortal para os organismos do fitoplâncton. Os corantes utilizados foram o vermelho neutro e azul de Evans, os quais são bem estabelecidos para a detecção da viabilidade destes organismos. O tratamento de ozônio foi o que teve maior afinidade com os corantes em questão, apesar de que para algumas espécies causou o rompimento da membrana, impossibilitando a permeabilidade dos corantes. O UV, por sua ação que não necessariamente induz a morte das células, não possibilitou a detecção da viabilidade por corantes com alta eficácia. É preciso mais estudos com este tratamento para saber se a coloração é um método eficaz após a ação do UV. Não foi possível a coloração das células após o uso do Peraclean, o qual descoloriu os corantes. Desta forma, a detecção da viabilidade com este tratamento não pode ser pela coloração. Também foram feitos experimentos de simulação das condições do tanque de lastro e o vermelho neutro foi eficaz para detectar a viabilidade celular do fitoplâncton em quaisquer condições ambientais e de vida das células.
\end{abstract}

Palavras-chave: azul de Evans, vermelho neutro, água de lastro, tratamento de ozônio 


\begin{abstract}
The transport of organisms through ballast water has been one of the most concerning marine impacts nowadays. Besides allowing the invasion of exotic species into new habitats it damages the local ecology, human health and socio-economic activities. To minimize this problem the IMO (International Maritime Organization) recommended the ships to perform ballast water exchange at the open ocean. However, in addition to the difficulties regarding the validation of this procedure, it does not guarantee the total elimination of organisms, including phytoplankton. Thus, several treatments are being developed to be implemented in ballast water tanks, including physical, mechanical and chemical methods. The goal of this study was to evaluate methods for validating the effectiveness of some treatments of ballast water, including UV radiation, ozone and the germicide Peraclean, using vital and mortal staining of phytoplankton cells. The dyes used were neutral red and Evans blue which are well established for detecting the viability of these organisms. The ozone treatment was the one with highest affinity with these dyes, though in some species it caused the rupture of the membrane, disabling the permeability of the dyes. UV treatment not necessarily led to cell death and thus did not allow viability detection by staining. Further studies are needed with this treatment to evaluate whether alternative staining methods (e.g., using fluorescent stains) allows an effective detection after UV action. Cell staining was not possible after the Peraclean treatment because it caused cell bleaching, making viability detection with this treatment impossible by staining. Experiments simulating environmental conditions of ballast water tanks showed that phytoplankton cell viability can be determined by neutral red staining in different situations.
\end{abstract}

Keywords: Evans blue, neutral red, ballast water, ozone treatment 


\subsection{Introdução}

O transporte e distribuição de espécies não nativas através da água de lastro de navios é uma das grandes ameaças para o ecossistema marinho (Carlton, 1985; Ruiz et al., 2000; Stehouwer et al., 2009; Butrón et al., 2011). Organismos não nativos que conseguem sobreviver no novo ambiente e se tornam a espécie dominante são conhecidos como invasores, e, na maioria das vezes, estes invasores causam impactos ecológicos, econômicos ou na saúde pública (Pimentel et al., 2000).

Os principais organismos transportados e largamente distribuídos pela água de lastro fazem parte do plâncton, como bactérias, microalgas, larvas de peixes e de animais bentônicos, além de organismos gelatinosos como medusas e ctenóforos (USEPA, 2011). Muitos fatores podem influenciar a viabilidade destes organismos durante a viagem nos tanques de lastro, como a ausência de luz, mudança na salinidade, temperatura, turbidez, falta de oxigênio, entre outros. Além de diversas espécies serem resistentes a estes fatores, algumas têm a capacidade de encistar e retornar à viabilidade ao serem descarregadas nas águas do porto de destino (Hallegraef, 1998; Gregg \& Hallegraef, 2007). Um período pequeno dentro do tanque de lastro, no caso de viagens curtas, também aumenta a chance de sobrevivência dos organismos (Stehouwer et al., 2009).

Devido aos impactos ambientais, econômicos e sanitários causados pela água de lastro, foi adotada em 2004 pela Organização Marítima Internacional (IMO, na sigla em inglês) a Convenção Internacional para o Controle e Gestão da Água de Lastro de Navios e Sedimentos (IMO, 2004), a qual estabeleceu limites máximos permissíveis para concentrações de organismos viáveis na água de lastro a ser descarregada no porto de destino. Estas concentrações são: 1) menos de 10 organismos viáveis por $\mathrm{m}^{3}$ com dimensão mínima $\geq 50 \mu \mathrm{m}$, e 2) menos de 10 organismos viáveis por $\mathrm{mL}$ com dimensão mínima entre 10 e $50 \mu \mathrm{m}$. Além destes limites, foram aprovadas regulamentações específicas para bactérias (Vibrio cholerae, Escherichia coli e enterococos intestinais) presentes na água de lastro (IMO, 2004).

Antes desta convenção, a IMO já tinha divulgado a resolução A.868(20) recomendando a troca da água de lastro em mar aberto (IMO, 1998), pois as espécies de regiões estuarinas e costeiras, onde se localizam os portos, não sobreviveriam ao serem lançadas em ambiente oceânico e vice-versa. Entretanto, este procedimento foi considerado como uma solução provisória, pois não garante a total eliminação dos 
organismos (Hülsmann \& Galil, 2001), além de ser difícil a validação por meio da inspeção portuária (GGPAF, 2002).

Para atender as demandas da convenção da IMO, estão sendo desenvolvidos e testados diferentes sistemas de tratamento da água de lastro (Herwig et al., 2006; Gregg et al., 2009), incluindo métodos mecânicos (filtração, hidrociclone), físicos (radiação ultravioleta, ozônio, aquecimento) e químicos (substâncias ativas, biocidas), com o objetivo de remover, matar ou inativar os organismos presentes na água de lastro (First \& Drake, 2013).

Geralmente, o tratamento mecânico é utilizado como uma etapa inicial para a retirada de organismos ou partículas de maiores dimensões, não sendo considerada uma solução completa, como a radiação ultravioleta (UV), um dos mais utilizados no sistema de gestão da água de lastro, normalmente usada em conjunto com outro tipo de método (Gregg et al., 2009).O principal efeito esperado do UV é de inativar a replicação do material genético das células, tornando-as não viáveis, ou seja, previne a reprodução, mas não necessariamente mata as células (Stehouwer et al., 2009; First \& Drake, 2013).

O ozônio já tem sido comumente usado no tratamento de água de consumo há vários anos, mas sua química na água do mar é complexa, devido à reação com o íon brometo, resultando em ácido hipobromoso $(\mathrm{HBrO})$ e íon hipobromito $\left(\mathrm{OBR}^{-}\right)$, compostos os quais têm efeito desinfetante (Hoigné, 1998). Apesar das incertezas sobre as consequências do ozônio, como possível toxicidade para bactérias, peixes e organismos do plâncton no porto de chegada, é um tratamento com grande potencial de uso e, por isso, está sendo muito estudado (Summerfelt, 2003; Herwig et al., 2006; Wright et al. 2010).

Existem vários agentes biocidas, também denominados substâncias ativas, sendo considerados para uso no tratamento da água de lastro. Um exemplo é o Peraclean® Ocean, o qual é um líquido composto de ácido peracético (PAA) e peróxido de hidrogênio $\left(\mathrm{H}_{2} \mathrm{O}_{2}\right)$, cuja eficácia para eliminar organismos da água de lastro têm sido demonstrada (Fuchs \& de Wilde, 2004; Lafontaine et al., 2008).

A detecção da viabilidade celular da comunidade planctônica presente na água de lastro é de extrema importância para a validação da eficácia do tratamento, mas é também um dos maiores desafios tecnológicos para a gestão deste vetor de espécies exóticas. Não é prático utilizar de forma rotineira na inspeção da água de lastro técnicas 
que demorem um tempo excessivo para gerarem resultados, como, por exemplo, a observação do crescimento celular após o tratamento (Liebich et al., 2012).

O uso de corantes para marcar organismos uni- e multicelulares viáveis ou inviáveis é uma técnica promissora para implementação em sistemas de inspeção da água de lastro. Por exemplo, usando corantes, Tang et al. (2011) e Stehouwer et al. (2013) mostraram que a eliminação de micro-organismos não é totalmente efetiva após diversos tipos de tratamento.

No presente estudo foram testados os corantes vermelho neutro (VN) e azul de Evans (EB) como métodos de verificação da viabilidade dos organismos após tratamento de amostras em condições de laboratório. Os tratamentos utilizados foram radiação ultravioleta, ozônio e o germicida Peraclean, em amostras de fitoplâncton cultivados.

Além disso, foi avaliada a eficácia do corante vermelho neutro quando aplicado aos organismos em diferentes fases de crescimento e condições experimentais, como a privação de radiação luminosa, situação semelhante à encontrada durante $\mathrm{o}$ aprisionamento de populações fitoplanctônicas nos tanques de água de lastro.

\subsection{Material e métodos}

\subsubsection{Espécies de fitoplâncton}

As espécies de fitoplâncton utilizadas neste trabalho são pertencentes a diferentes grupos taxonômicos, a saber: Alexandrium tamiyavanichii, Chattonella sp., Prorocentrum gracile, Tetraselmis gracilis e Thalassiosira pseudonana.

As cepas foram provenientes do Banco de Micro-organismos Marinhos Aidar \& Kutner (BMA\&K) e do Laboratório de Sistemas Planctônicos (LAPS), ambos do Instituto Oceanográfico da USP.

Estes microrganismos foram cultivados em meio Guillard f/2 (Guillard, 1975), salinidade 37, em frascos devidamente esterilizados (Kawachi \& Noël, 2005; Lourenço, 2006) e mantidos no BMA\&K/IOUSP, local onde já existe a infraestrutura para os cultivos, como fluxo laminar (Pa 420 Eco - Pachane) para o preparo dos meios de cultura, câmaras de germinação com controle de temperatura $\left(23 \pm 1{ }^{\circ} \mathrm{C}\right)$, de fotoperíodo (12 horas diárias) e de intensidade luminosa $\left(180 \mu \mathrm{E} \mathrm{m}^{2} \mathrm{~s}^{-1}\right)$.

Para os testes com os tratamentos foram utilizados cultivos em fase exponencial de crescimento, partindo do pressuposto que a maioria das células em 
cultivo nesta fase estão vivas, portanto, as células mortas seriam resultantes do tratamento utilizado. As amostras controle dos experimentos foram submetidas ao aquecimento por banho-maria (Nalgon) a $80{ }^{\circ} \mathrm{C}$ por 15 minutos para a morte das células.

Para a execução do experimento do monitoramento da viabilidade, foram cultivadas nove réplicas desde o início para as espécies $P$. gracile e T. pseudonana. Este experimento será melhor detalhado no item 2.2.6.

\subsubsection{Coloração e viabilidade}

Os corantes utilizados neste trabalho foram o vermelho neutro (Fluka, Sigma Aldrich) e azul de Evans (Sigma Aldrich), ambos preparados a 1\% em água destilada. As soluções estoque foram mantidas em frascos âmbar, envoltos com papel alumínio, a $4^{\circ} \mathrm{C}$.

Após a adição dos corantes, as amostras foram colocadas na câmara de contagem Nageotte e observadas sob microscópio multizoom Nikon AZ100. As células coradas e não coradas foram contadas com auxílio de contadores manuais. Para as espécies menos densas, toda a câmara foi contabilizada, e para as espécies com maiores densidades celulares, foi feita a contagem até 400 células (Lourenço, 2006), método tradicionalmente usado para contagens de fitoplâncton.

\subsubsection{Radiação ultravioleta}

Cada espécie de fitoplâncton foi colocada em mini placas de Petri de vidro (5 cm de diâmetro), em cinco réplicas. As concentrações celulares iniciais de cada espécie estão listadas na tabela 2.1.

Tabela 2.1. Densidades médias dos cultivos utilizados no experimento de tratamento com UV.

\begin{tabular}{lc}
\hline & Densidades médias $\left(\right.$ cel. $\left.\mathrm{mL}^{-1}\right)$ \\
\hline A. tamiyavanichii & $5,20 \times 10^{2}$ \\
Chattonella $\mathrm{sp}$. & $1,49 \times 10^{3}$ \\
$P$. gracile & $3,86 \times 10^{2}$ \\
T. gracilis & $1,67 \times 10^{5}$ \\
T. pseudonana & $7,45 \times 10^{4}$ \\
\hline
\end{tabular}


Estas placas de vidro, compatíveis para a penetração do UV, foram colocadas em câmara de fluxo laminar, com exposição da lâmpada germicida UV-C ( $\lambda 254 \mathrm{~nm}$ ) por 40 minutos, a cerca de 1 metro de distância (Fig. 2.1). Uma das réplicas foi utilizada como controle e submetida ao aumento de temperatura no banho-maria.
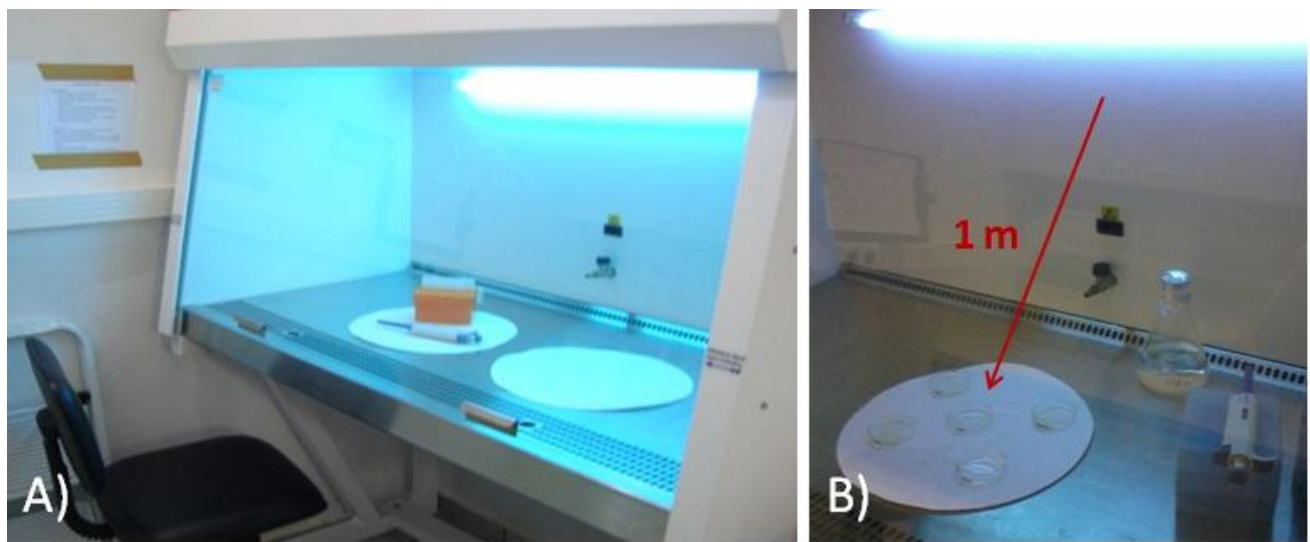

Figura 2.1. Em A, o fluxo laminar com a lâmpada UV-C ligada; em B, modo e distância de como as amostras ficaram expostas à radiação UV.

Após o tempo de tratamento, $1 \mathrm{~mL}$ de amostra de cada réplica foi colocado em um nicho de uma placa multipoços (Fig. 2.2) e os corantes vermelho neutro (1,5 $\mu \mathrm{L}) \mathrm{e}$ azul de Evans $(3,5 \mu \mathrm{L})$ foram adicionados. Após 20 minutos, cada amostra corada foi analisada em câmara de contagem Nageotte sob microscópio e as células coradas e não coradas foram contadas manualmente.

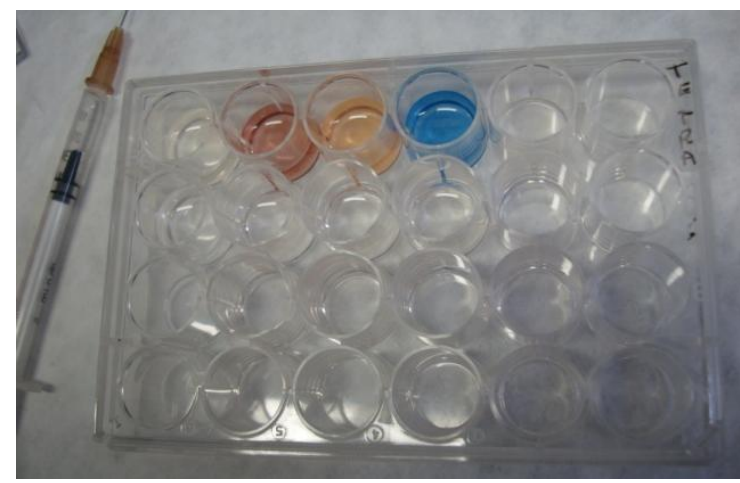

Figura 2.2. Placa multipoços de acrílico, onde as amostras tratadas foram alocadas para a posterior adição dos corantes vermelho e azul de Evans. Cada poço continha $1 \mathrm{~mL}$ de amostra por réplica. 


\subsubsection{Ozônio}

Foram utilizados erlenmeyers de vidro com $100 \mathrm{~mL}$ de cultivo de cada espécie, quatro réplicas cada, para a aplicação do ozônio, a qual teve o auxílio dos técnicos da empresa Brasil Ozônio (Fig. 2.3). As densidades celulares de cada espécie estão listadas na tabela 2.2. Para este pequeno volume, os técnicos recomendaram a vazão de $2 \mathrm{~L}$ min. ${ }^{-1}$ de oxigênio, com concentração de ozônio a $35 \mathrm{~g} \mathrm{~m}^{-3}$ para um período máximo de 1 minuto de exposição.

Tabela 2.2. Densidades médias dos cultivos utilizados no experimento de tratamento com ozônio.

\begin{tabular}{lc}
\hline & Densidades médias $\left(\right.$ cel. $\left.\mathrm{mL}^{-1}\right)$ \\
\hline A. tamiyavanichii & $8,32 \times 10^{2}$ \\
Chattonella $\mathrm{sp}$. & $1,25 \times 10^{3}$ \\
$P$. gracile & $4,52 \times 10^{2}$ \\
T. gracilis & $1,04 \times 10^{5}$ \\
T. pseudonana & $9,43 \times 10^{4}$ \\
\hline
\end{tabular}

A aplicação foi feita através de mangueira, com pedra difusora na ponta, por onde passava o gás ozônio, o qual que era produto da transformação do oxigênio pelo equipamento da empresa (Fig. 2.3). Após 1 minuto de exposição ao ozônio, as amostras foram semi-tampadas com tampão de algodão e mantidas em temperatura ambiente por 24 horas, antes da adição dos corantes. Este procedimento foi necessário para garantir a evaporação total do ozônio, pois este composto também tem efeito de descoloração, além de desinfetante (Camel \& Bermond, 1998). Isso foi observado por nós ao adicionar o corante na amostra logo após o tratamento e o corante sumir.

Para o tratamento controle, as amostras de cada espécie foram submetidas ao aquecimento por banho-maria, como mencionado no tópico anterior.

Após as 24 horas, $1 \mathrm{~mL}$ de amostra de cada réplica, tratadas com o ozônio e do controle, foi colocado na placa multipoços, onde foram adicionados os corantes vermelho neutro $(1,5 \mu \mathrm{L})$ e azul de Evans $(3,5 \mu \mathrm{L})$ (individualmente) para a avaliação da viabilidade. Passados 20 minutos de ação dos corantes, cada amostra foi analisada na câmara Nageotte, e as células coradas e não coradas foram contadas com contadores manuais. 


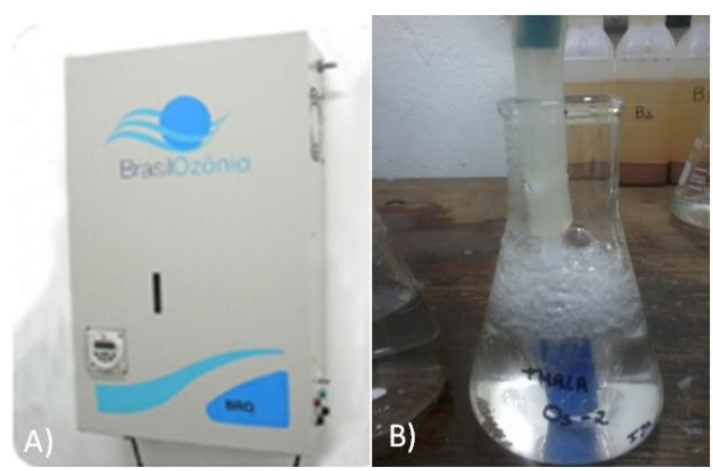

Figura 2.3. Em A, o equipamento da Brasil Ozônio que transforma $\mathrm{O}_{2}$ em $\mathrm{O}_{3}$ (Fonte da imagem: www.brasilozonio.com.br); em B, aplicação do ozônio na amostra através da pedra difusora na mangueira.

\subsubsection{Peraclean}

Antes do uso nas amostras, foi feita uma diluição do germicida Peraclean Ocean (15\%) com água destilada (1 produto : 2 água) e armazenado em um frasco âmbar a $4^{\circ} \mathrm{C}$ por 2 semanas.

Para o experimento, $1 \mathrm{~mL}$ de amostra de cada espécie foi colocada em cada nicho de uma placa multipoços, em quatro réplicas. Em seguida, foram adicionados 2,0 $\mu \mathrm{L}$ do germicida em cada amostra. Por último, foram adicionados individualmente os corantes vermelho neutro $(1,5 \mu \mathrm{L})$ e azul de Evans $(3,5 \mu \mathrm{L})$ para o teste de viabilidade. Após 20 minutos de ação do corante, as amostras foram colocadas na câmara Nageotte para a contagem das células sob microscópio. Uma quinta réplica para cada espécie foi usada como tratamento controle, após ser submetida ao aquecimento.

\subsubsection{Teste de monitoramento da viabilidade}

Para os experimentos de monitoramento da viabilidade das microalgas nas condições simuladas de um tanque de lastro, foram analisados os cultivos das espécies Thalassiosira pseudonana e Prorocentrum gracile em erlenmeyers de $100 \mathrm{~mL}$ de capacidade.

Três réplicas de cada espécie foram avaliadas em três tratamentos: controle, semi-fechado e semi-aberto. O termo "aberto" implica na exposição das culturas à radiação luminosa, em contraponto ao termo "fechado", no qual os erlenmeyers com 
cultivo foram envoltos em papel alumínio para manter as células totalmente no escuro. O tratamento controle se manteve, durante todo o experimento, sob condições ideais de cultivo, exposto à luz em fotoperíodo de 12 horas diárias.

O tratamento semi-fechado foi envolto em papel alumínio desde o início do experimento, de forma a observar o comportamento de uma cultura em início do crescimento na situação onde não há incidência de radiação luminosa, como se estivesse dentro do tanque de lastro. Transcorridos aproximadamente 15 dias do experimento, o papel alumínio foi retirado e as culturas submetidas a um fotoperíodo de 12 horas diárias, de forma a simular uma situação de descarga de água de lastro e nova exposição das células viáveis à luz. Além disso, adicionou-se uma nova dose de nutrientes a estas culturas de forma a simular a situação análoga após a descarga em um porto de destino em região estuarina ou costeira com alta disponibilidade de nutrientes dissolvidos. Estes nutrientes foram provenientes da adição do meio f/2 (Guillard, 1975), exceto para a solução de vitaminas, a qual foi adicionada a metade do volume (f/4). Para a diatomácea T. pseudonana também foi adicionada a solução de sílica.

O terceiro tratamento, semi-aberto, foi inverso ao semi-fechado: inicialmente as réplicas foram mantidas sob fotoperíodo de 12 horas diárias (assim como o grupo controle), porém foram envoltas em papel alumínio após duas semanas, a fim de analisar a viabilidade de uma cultura na fase exponencial após o aprisionamento em um ambiente escuro, simulando um tanque de lastro.

Os testes de viabilidade foram baseados apenas na ação do vermelho neutro, no volume de 1,5 uL do corante a cada $1 \mathrm{~mL}$ de cultura, por 20 minutos. As amostras foram transferidas para a câmara Nageotte e analisadas sob o microscópio Nikon AZ100. As células coradas e não coradas foram contadas manualmente. $O$ intervalo entre observações dos tratamentos experimentais e controles (alíquota de $1 \mathrm{~mL}$ por réplica) variou de 1 a 3 dias. 


\subsection{Resultados}

\subsubsection{Radiação ultravioleta (UV)}

Dentre os corantes testados, o vermelho neutro foi o que teve melhores resultados em detectar a mortalidade após o tratamento com UV, variando de $65,6 \%$ de mortalidade para $P$. gracile a $100 \%$ para a A. tamiyavanichii. O azul de Evans teve menor eficiência para coloração após esse tipo de tratamento, variando de 6,9\% para $P$. gracile a 52,7\% de mortalidade para Chattonella sp. (Tabela 2.3, Figura 2.4).

Não foram feitos testes com o vermelho neutro para Chattonella sp. e nem com o azul de Evans para T. gracilis, pois já foi demonstrado que estes corantes não coram estas espécies (Capítulo 1) e inclusive podem causar efeito tóxico, no caso do vermelho neutro com Chattonella sp.

Tabela 2.3. Média da porcentagem de mortalidade das células após o tratamento com UV, detectada pelos corantes vermelho neutro e azul de Evans; e média do número de células contabilizadas em cada contagem. Os controles são com o tratamento de aumento de temperatura.

\begin{tabular}{|c|c|c|c|c|c|}
\hline \multirow[b]{2}{*}{ ESPÉCIE } & \multirow[b]{2}{*}{ AMOSTRA } & \multicolumn{2}{|c|}{ VERMELHO NEUTRO } & \multicolumn{2}{|c|}{ AZUL DE EVANS } \\
\hline & & $\%$ Mortalidade & $\begin{array}{c}\text { Média do no } \\
\text { de cel. } \\
\text { contadas }\end{array}$ & $\begin{array}{c}\% \\
\text { Mortalidade }\end{array}$ & $\begin{array}{c}\text { Média do no } \\
\text { de cel. } \\
\text { contadas }\end{array}$ \\
\hline \multirow{2}{*}{ A. tamiyavanichii } & Tratamento & 100 & 21,5 & 7.2 & 32,25 \\
\hline & Controle & 100 & 44 & 21,7 & 32 \\
\hline Chattonella sn & Tratamento & \multirow{2}{*}{\multicolumn{2}{|c|}{ Não se aplica }} & 6,9 & 57,75 \\
\hline Cratlomerla sp. & Controle & & & 97,8 & 89 \\
\hline$T$ aracilis & Tratamento & 75,6 & 408,5 & \multirow{2}{*}{\multicolumn{2}{|c|}{ Não se aplica }} \\
\hline 1. gracills & Controle & 99,6 & 458 & & \\
\hline \multirow{2}{*}{ P. gracile } & Tratamento & 65,6 & 21,5 & 52,7 & 18 \\
\hline & Controle & 100 & 5 & 70,0 & 30 \\
\hline \multirow{2}{*}{ T. pseudonana } & Tratamento & 71,9 & 410,5 & 49,0 & 422,5 \\
\hline & Controle & 100 & 448 & 100,0 & 452 \\
\hline
\end{tabular}

As amostras controle tiveram melhores resultados de coloração pósaquecimento, em relação às que foram submetidas ao UV. Todas as espécies tiveram $100 \%$ de mortalidade detectada pelo vermelho neutro, e variação entre $21,7 \%$ para $A$. tamiyavanichii a $100 \%$ de mortalidade para T. pseudonana detectadas pelo azul de Evans.

Apesar dos corantes não terem detectado 100\% de mortalidade das células após a exposição ao UV, ao fazer as contagens no microscópio foram feitas observações de 
rugosidade das membranas e imobilização de todas as células da espécie $T$. gracilis, indicando algum efeito causado pelo UV. Outro indício observado foi com as células de A. tamiyavanichii, devido ao grande número de tecas livres em todas as amostras analisadas. Ou seja, além da média encontrada de 21,5 células por amostra com vermelho neutro, foi contabilizada também uma média de 17 tecas. E nas amostras com azul de Evans, além da média de 32,5 células contadas por amostra, foi encontrada uma média de 47 tecas livres por réplica.

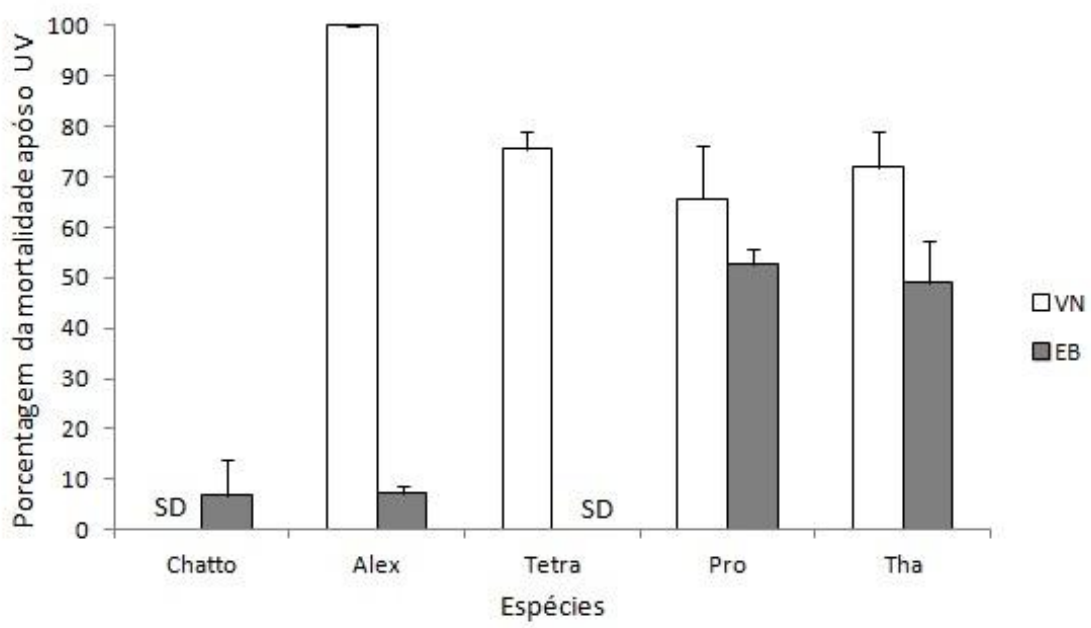

Figura 2.4. Porcentagem da média das células mortas (não coradas pelo VN - vermelho neutro ou coradas pelo EB - azul de Evans) após o tratamento com UV para cada espécie. As barras verticais indicam o erro padrão. SD indica "Sem dados", no caso dos corantes que não funcionam em determinadas espécies. Chatto: Chattonella sp., Alex: Alexandrium tamiyavanichii, Tetra: Tetraselmis gracilis, Pro: Prorocentrum gracile, Tha: Thalassiosira pseudonana.

\subsubsection{Ozônio}

O tratamento de ozônio causou o rompimento da membrana e a destruição das células das espécies Chattonella sp. e T. pseudonana, o que impossibilitou a contagem e a verificação da viabilidade por corantes, pois não houve células íntegras para serem coradas após o tratamento.

Para as outras espécies, o teste com o vermelho neutro resultou em $75 \%$ de mortalidade para $P$. gracile e $100 \%$ para T. gracilis. Entretanto, não foi detectada nenhuma célula morta de A. tamiyavanichii após a reação com o ozônio, sendo que 
$100 \%$ das células contadas estavam coradas pelo vermelho neutro, ou seja, vivas (Tabela 2.4, Fig. 2.5).

O azul de Evans teve relativamente melhor eficácia que o vermelho neutro em marcar células após o ozônio, pois para as espécies testadas houve mais que 99\% de mortalidade, ou seja, de células coradas, além de ter pequenos erros padrão (Tabela 2.4, Fig. 2.5). Inclusive, A tamiyavanichii teve $100 \%$ de mortalidade, resultado contrário obtido pelo vermelho neutro $(0 \%)$.

Em relação ao controle, para as duas espécies de dinoflagelados testados com o azul de Evans, houve maior eficiência dos corantes após tratamento com ozônio, do que após o aquecimento, provando alta afinidade deste corante com este tipo de tratamento. Já para o vermelho neutro, a eficiência após o aumento de temperatura foi melhor do que após a ozonação, sendo que no primeiro caso houve mais de 99,6\% de mortalidade, e após o ozônio a porcentagem de mortalidade variou entre 67,6 e 70\% (Tabela 2.4).

Tabela 2.4. Média da porcentagem de mortalidade das células após o tratamento com ozônio, detectada pelos corantes vermelho neutro e azul de Evans; e média do número de células contabilizadas em cada contagem. Os controles são com o tratamento de aumento de temperatura

\begin{tabular}{|c|c|c|c|c|c|}
\hline \multirow[b]{2}{*}{ ESPÉCIE } & \multirow[b]{2}{*}{ AMOSTRA } & \multicolumn{2}{|c|}{ VERMELHO NEUTRO } & \multicolumn{2}{|c|}{ AZUL DE EVANS } \\
\hline & & $\begin{array}{c}\% \\
\text { Mortalidade }\end{array}$ & $\begin{array}{c}\text { Média do no } \\
\text { de cel. } \\
\text { contadas }\end{array}$ & $\begin{array}{c}\% \\
\text { Mortalidade }\end{array}$ & $\begin{array}{c}\text { Média do no } \\
\text { de cel. } \\
\text { contadas }\end{array}$ \\
\hline \multirow{2}{*}{ A. tamiyavanichii } & Tratamento & 0 & 12,5 & 99,3 & 71,25 \\
\hline & Controle & 100 & 44 & 67,6 & 37 \\
\hline \multirow{2}{*}{ P. gracile } & Tratamento & 75,4 & 20,75 & 100 & 27 \\
\hline & Controle & 100 & 5 & 70 & 30 \\
\hline \multirow{2}{*}{ T. gracilis } & Tratamento & 100 & 402 & \multirow{2}{*}{\multicolumn{2}{|c|}{ Não se aplica }} \\
\hline & Controle & 99,6 & 456 & & \\
\hline T. pseudonana & $\begin{array}{c}\text { Tratamento } \\
\text { Controle }\end{array}$ & \multicolumn{4}{|c|}{ Rompimento das células } \\
\hline Chattonella sp. & $\begin{array}{c}\text { Tratamento } \\
\text { Controle }\end{array}$ & \multicolumn{4}{|c|}{ Rompimento das células } \\
\hline
\end{tabular}




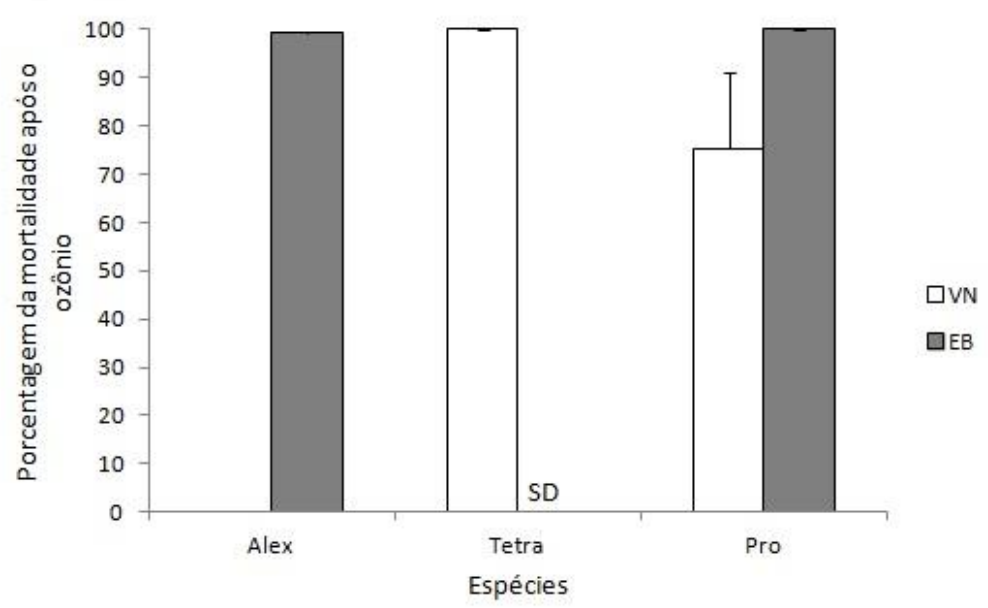

Figura 2.5. Porcentagem da média das células mortas (não coradas pelo VN - vermelho neutro ou coradas pelo EB - azul de Evans) após o tratamento de ozônio de cada espécie. A barra vertical inica o erro padrão. SD indica "Sem dados", no caso dos corantes que não funcionam em determinadas espécies. Alex: Alexandrium tamiyavanichii, Tetra: Tetraselmis gracilis, Pro: Prorocentrum gracile.

\subsubsection{Peraclean}

Não foi possível a determinação quantitativa do teste de viabilidade após o tratamento com o Peraclean, pois este produto resultou na descoloração dos corantes. Foram feitas observações microscópicas das espécies após a adição do germicida e notou-se a imobilização das células, o que pode indicar a funcionalidade do Peraclean em esterilizar os micro-organismos. Porém, a coloração vital e mortal do vermelho neutro e azul de Evans não poderá ser usada como método de validação deste tratamento.

\subsubsection{Teste de monitoramento da viabilidade}

\section{Prorocentrum gracile}

No grupo controle, a análise dos indivíduos viáveis resultou em uma curva típica de crescimento de microalgas em condições ideais de crescimento (Fig. 2.6).

No tratamento semi-fechado foram observados efeitos deletérios nas células desde os primeiros dias do experimento, como células pequenas, frágeis e com baixa mobilidade. Ao final de uma semana foram contabilizados apenas um ou dois indivíduos corados pelo vermelho neutro (vivos) em toda a câmara de contagem. A 
partir do $18^{\circ}$ dia, o papel alumínio foi retirado, e consequentemente o meio foi exposto à radiação luminosa. Este fato, associado à adição de uma nova dose de nutrientes, poderia levar à recuperação da população desta espécie. No entanto, não foram observadas mudanças significativas de crescimento (Fig. 2.6).

Nas primeiras duas semanas do tratamento semi-aberto, o desenvolvimento das culturas foi similar ao tratamento controle, como o esperado. Após o $18^{\circ}$ dia, quando os erlenmeyers foram envoltos em papel alumínio, o bloqueio de radiação luminosa não gerou imediatamente efeitos negativos para uma cultura em fase de crescimento, em contraste com culturas jovens, como observado no tratamento SF. Somente após o $21^{\circ}$ dia houve queda abrupta do número de células viáveis e aumento do número de células inviáveis (Fig. 2.6).
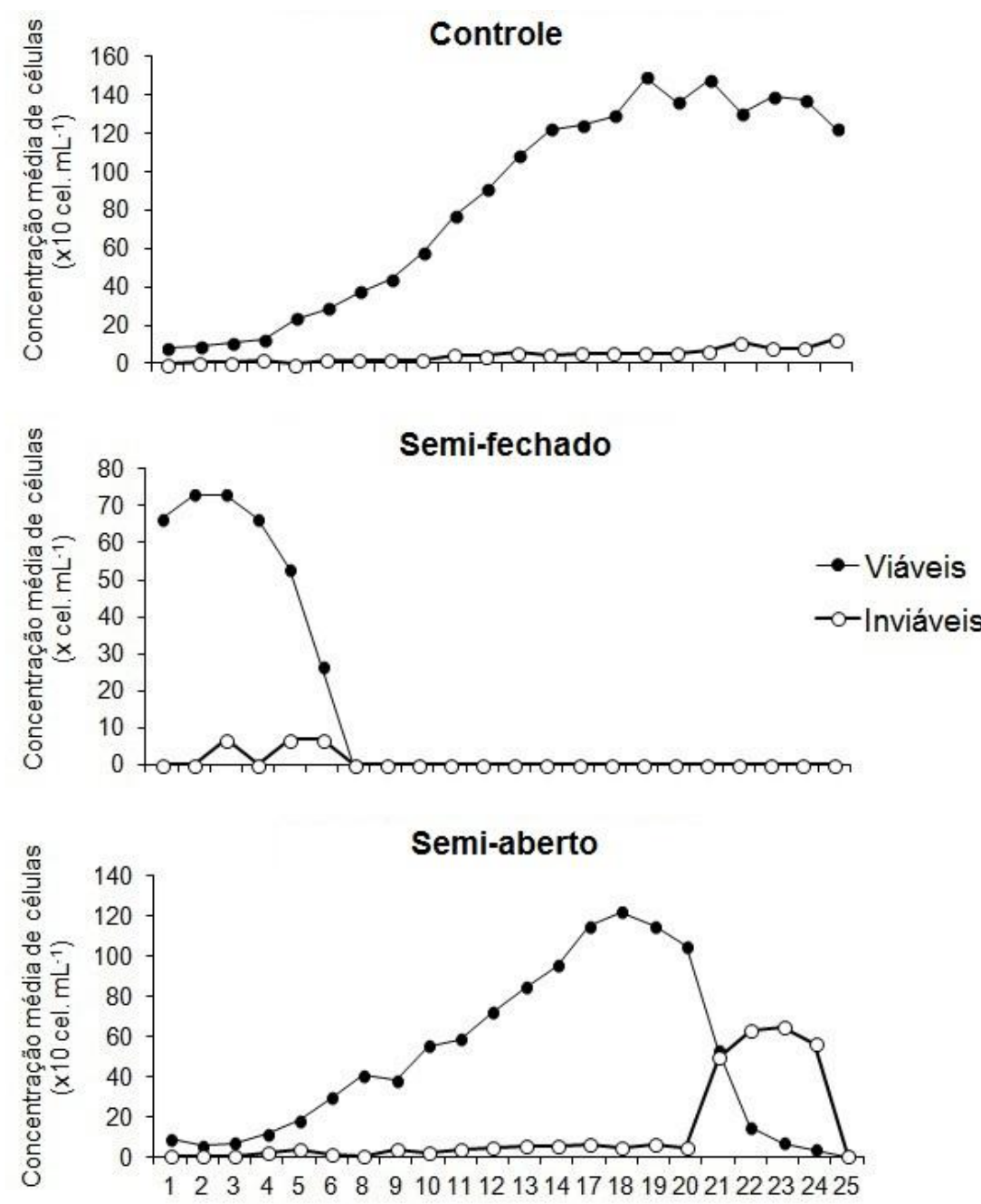

Dias

Figura 2.6. Concentrações médias de células viáveis e inviáveis em cada tratamento (controle, semi-fechado, e semi-aberto) de Prorocentrum gracile, durante os 25 dias do experimento. As células viáveis foram coradas pelo vermelho neutro. 


\section{Thalassiosira pseudonana}

No tratamento controle, como ocorreu com $P$. gracile, o fotoperíodo de 12 horas diárias e a disponibilidade de nutrientes permitiram o crescimento normal das culturas, com a diminuição do número de células viáveis apenas após o $18^{\circ}$ dia, provavelmente no início da fase senescente (Fig.2.7).

As réplicas do tratamento semi-fechado tiveram baixas concentrações de células viáveis e inviáveis no período em que os erlenmeyers estavam cobertos com o papel alumínio. Após 12 dias, com a retirada do papel alumínio, e a consequente exposição à radiação luminosa e nova dose de nutrientes, permitiu o aumento de concentração de células seguindo um padrão exponencial, com fase estacionária na terceira semana (Fig. 2.7).

No tratamento semi-aberto, observou-se um crescimento exponencial ao longo da primeira semana, similar do tratamento controle, porém com o estabelecimento da fase estacionária a partir do sexto dia até o final do experimento. Para este grupo, não houve alteração em suas respectivas concentrações celulares com a interrupção da irradiação luminosa a partir do $12^{\circ}$ dia (Fig. 2.7). Contudo, em observações microscópicas foram notadas modificações morfológicas, como por exemplo, células enrugadas e de menor tamanho, indicando a deterioração progressiva do meio no ambiente escuro. 


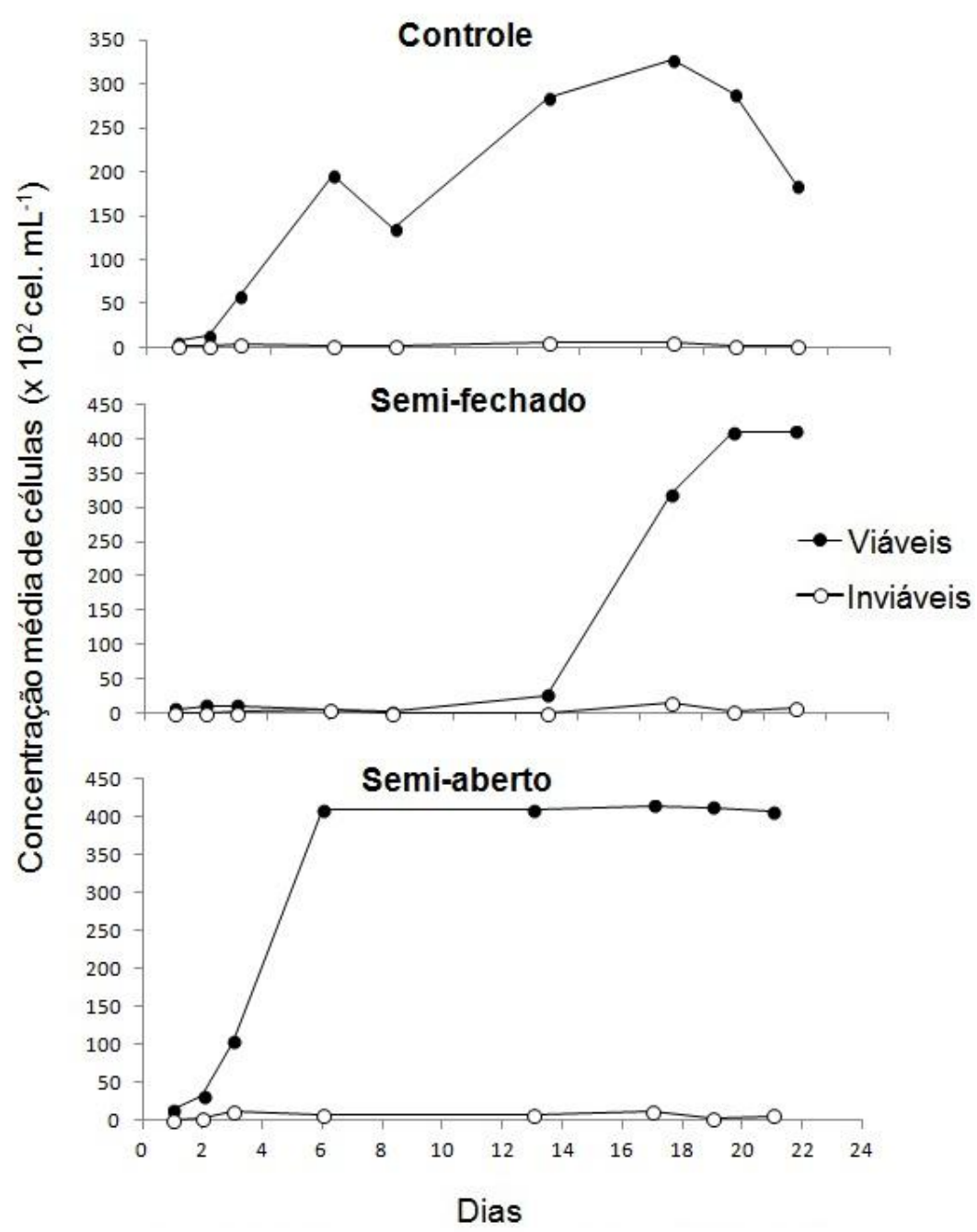

Figura 2.7. Concentrações médias de células viáveis e inviáveis em cada tratamento (controle, semi-fechado, e semi-aberto) de Thalassiosira pseudonana, durante os dias do experimento. As células viáveis foram coradas pelo vermelho neutro.

\subsection{Discussão}

\section{Radiação ultravioleta}

A principal descoberta deste estudo foi revelar quais tipos de tratamentos da água de lastro, usados para a eliminação de organismos vivos, podem ser validados pelo método de coloração vital e mortal.

Os resultados de coloração do fitoplâncton após o tratamento com o UV foram pouco eficazes se comparado com o tratamento controle de aquecimento. Não foi objetivo deste estudo explorar a eficácia do tratamento em si, mas a baixa afinidade dos 
corantes após a exposição ao UV pode ser devido tanto à inibição da coloração após o efeito do UV, como o tratamento não ter sido totalmente eficaz para matar as células.

Neste caso, seria necessário incubar e analisar o crescimento das células que foram submetidas ao UV para comparar com os resultados dos corantes. Se uma amostra não tiver crescimento celular e não foi marcada pelo corante mortal azul de Evans, podemos concluir que o corante não funciona após o UV. Da mesma forma com o corante vital vermelho neutro, caso a amostra apresente crescimento celular, mas sem coloração das células.

Porém, há estudos que indicam a potencialidade do UV no bloqueio da capacidade reprodutiva e não necessariamente na morte da célula (Waite et al., 2003; Stehouwer et al., 2009; First \& Drake, 2013). Desta forma, as células que não coraram com o azul de Evans não estariam mortas, mas poderiam estar inviáveis em termos reprodutivos, o que indicaria conformidade com a regulamentação da IMO.

Entretanto, Stehouwer et al. (2009) comprovaram o crescimento de células após 7 ou 8 dias do tratamento com o UV. Mesmo em experimentos que aplicaram o UV duas vezes, os autores não encontraram mortalidade significativa dos organismos, a qual foi analisada através da autofluorescência, pelo fluorímetro PAM (Pulse Amplitude Modulated). Liebich et al. (2012) também observaram o crescimento de espécies do gênero Thalassiosira em menos de 20 dias após a exposição ao UV.

Organismos aquáticos possuem diferentes tolerâncias ao UV, sendo as bactérias mais sensíveis e cistos de protistas e vírus mais resistentes (Hijnen et al., 2006). Tem sido comprovado que alguns micro-organismos fototróficos possuem estratégias de proteção ao UV-A e UV- B na zona eufótica, resistência ao UV-C e capacidade de reparar danos celulares causados pela radiação UV (First \& Drake, 2013). Isto pode explicar a mudança morfológica observada em T. gracilis e a liberação da teca por A. tamiyavanichii, como estratégias de defesa contra o UV. Estas implicações do tratamento com UV sugerem que são necessários mais estudos quantitativos e qualitativos com diferentes espécies de fitoplâncton após a exposição à radiação.

Os presentes resultados sugerem que a coloração vital ou mortal não é o melhor método para avaliar a eficácia de eliminação dos organismos deste tratamento. Se o UV pode causar a inibição da reprodução e nem sempre a morte celular, a análise do crescimento celular seria o método mais indicado, embora inviável na prática, devido ao tempo necessário para a geração de resultados. Outros métodos precisariam ser 
desenvolvidos para a avaliação do tratamento com UV na rotina de inspeção dos navios comerciais.

\section{Ozônio}

A avaliação do tratamento de ozônio pelo método de coloração foi bastante eficaz, principalmente com o corante azul de Evans (> 99\% de células mortas e coradas). Esta descoberta é de extrema relevância, pois os métodos mais frequentes para validação do tratamento de ozônio sob o fitoplâncton são por análise de crescimento celular e avaliação da clorofila a (Wright et al., 2010), mais demorados e duvidosos.

Herwig et al. (2006) fizeram testes com ozônio em tanques de água de lastro e observaram a diminuição da concentração do fitoplâncton após horas de tratamento. Apesar de não terem feito testes de viabilidade, assumiram que os organismos que decantaram estavam mortos $\mathrm{e}$, portanto, não seriam contabilizados. Tanto dinoflagelados como microflagelados tiveram altas reduções na concentração dos organismos após horas de tratamento. Entretanto, os autores encontraram concentrações mais variadas para as diatomáceas e acreditam que estes resultados podem ser devido às limitações da observação na microscopia, e que as frústulas de sílica não seriam degradadas pelo ozônio, o contrário do que ocorreu com a T. pseudonana neste trabalho, a qual teve a frústula rompida.

Para outras espécies, eles indicaram a lise celular após o ozônio e que este tratamento é eficaz para a remoção do fitoplâncton, como também foi visto no presente trabalho, para T. pseudonana e Chattonella sp. Apesar deste fato descartar o uso dos corantes, pois não há como a coloração ficar retida na célula, mostra que o ozônio é eficiente na eliminação do fitoplâncton, e a coloração pode ser usada para as células que permanecerem intactas.

\section{Peraclean}

Os resultados deste trabalho mostraram que a validação do tratamento com o germicida Peraclean não pode ser feita através da coloração vital ou mortal, pois esta substância ativa descolore os corantes, impossibilitando a detecção.

Alguns estudos defendem o uso das substâncias ativas por serem de ação imediata, se comparado com o efeito gradual da radiação UV, mesmo com a possibilidade de crescimento do fitoplâncton após dias do tratamento (Stehouwer et al., 
2013). Stehouwer et al. (2013) testaram o Ecochlor® usando dióxido de cloro e não houve crescimento de fitoplâncton durante as três semanas do experimento. Porém, Gregg \& Hallegraeff (2007) indicam que muitas espécies fitoplanctônicas são resistentes à radiação UV e substâncias ativas, por isso a importância de conhecer as espécies que estão presentes na água e fazer o estudo do crescimento celular após os tratamentos.

Entretanto, para um rápido monitoramento, como é o requerido pela IMO, o ideal seria a validação do tratamento pela rápida detecção da viabilidade pelos corantes. Apesar de neste estudo não termos tido resultados satisfatórios com o vermelho neutro e azul de Evans para a validação, espera-se no futuro fazer o mesmo estudo com os corantes fluorescentes, a fím de verificar se o Peraclean também irá descolorir estes marcadores.

\section{Teste de monitoramento da viabilidade}

O estudo do monitoramento da viabilidade em diferentes condições de luz das espécies $P$. gracile e $T$. pseudonana permitiram avaliar até que ponto a interrupção da radiação luminosa (simulada através do fechamento dos frascos com o papel alumínio), similar ao encontrado nos tanques dos navios, influencia na viabilidade destas espécies. Experimentos recentes indicam que populações microplanctônicas possuem a capacidade de se restabelecerem após o transporte em tanques de lastro, até mesmo após o emprego de métodos de tratamento da água (Liebich et al, 2012; Stehouwer et al, 2013).

Dos experimentos realizados, foi notado que a espécie Prorocentrum gracile, independente da fase de crescimento em que está, possui chances ínfimas de sobrevivência durante o translado dentro dos tanques escuros de lastro, já que teve queda abrupta no número de células viáveis imediatamente após a privação de luz. Uma possível alternativa à sobrevivência de espécies de microalgas em situações deste tipo envolve a seleção de indivíduos em forma de resistência (por exemplo, cistos) (Hallegraeff, 1998), porém isto não foi constatado para a espécie em questão. Apesar disso, o corante vermelho neutro foi eficaz para a detecção das células viáveis em toda a curva de crescimento, independente da condição ambiental, o que é mais uma vantagem deste marcador. 
A espécie Thalassiosira pseudonana, por outro lado, exibiu um comportamento inverso. O reestabelecimento da população após a retirada do papel alumínio indica que existe potencial resistência à privação de luz. Esta situação pode permitir que a espécie supere os processos de competição interespecífica e se estabeleça em uma nova região, no cenário real do transporte de organismos para diferentes regiões através da água de lastro. Vale estudar mais a resistência à privação de luz registrada para esta espécie, a qual pode ser útil como espécie indicadora para a validação de tratamentos.

O interessante destes experimentos foi que mesmo na fase senescente e nas situações de privação de luz o vermelho neutro marcou células viáveis e aparentemente não prejudicou ou causou lise das células, o que aumenta a aplicabilidade deste corante para diferentes situações encontradas nos tanques de lastro. Ou seja, tanto células em ótimas condições de crescimento exibiram a coloração, como também células viáveis na fase senescente.

\subsection{Conclusões}

Este capítulo comprovou a aplicabilidade dos corantes vermelho neutro e azul de Evans para a detecção da viabilidade celular após tratamentos usuais da água de lastro, além do aquecimento (visto no capítulo 1), que também é um tratamento físico utilizado nos tanques. Dentre eles, o ozônio teve grande destaque, pois além de ter apresentado eficiência na indução da morte celular, os corantes foram compatíveis como métodos de validação para as espécies em que não há ruptura da membrana, principalmente o azul de Evans. O único tratamento que não é possível a utilização dos corantes para validação foi com o germicida Peraclean. Entretanto, estudos futuros com corantes fluorescentes podem mostrar a aplicabilidade destas técnicas de marcação após este tipo de tratamento.

O tratamento com UV gerou dúvidas sobre até que ponto os corantes podem detectar as modificações celulares. São necessários experimentos adicionais para analisar o crescimento celular vários dias após o tratamento, juntamente com a análise dos corantes. Desta forma, é possível distinguir se o corante irá marcar apenas células vivas ou mortas (vitalidade), ou se também pode detectar a inviabilidade reprodutiva ou de crescimento da célula. 
Os experimentos de monitoramento de viabilidade indicaram a compatibilidade do corante vermelho neutro em qualquer fase de crescimento e situação de privação de luz para as espécies $P$. gracile e $T$. pseudonana. É interessante fazer mais estudos com outras espécies, com controle e amostragem rigorosa, a fim de analisar se os corantes não influenciam o estado fisiológico das células, principalmente no caso das células senescentes ou que estão em condições não ideais de crescimento.

Uma das descobertas deste experimento foi a resistência da espécie $T$. pseudonana em condições adversas, similares às dos tanques de lastro. Por isso, seria muito interessante em estudos futuros analisar se esta ou outras espécies poderiam ser indicadoras para validação de tratamentos da água de lastro.

Além do desenvolvimento de estudos adicionais relacionados à aplicação de corantes em amostras, a associação da automatização da análise de fitoplâncton por imagens, constitui um elemento chave para o avanço desta área do monitoramento ambiental. 


\section{Considerações finais}

Este trabalho mostrou a facilidade e possibilidade do uso de corantes vitais e mortais para identificar a viabilidade do fitoplâncton marinho. Dentre eles, os corantes vermelho neutro e azul de Evans mostraram grande aplicabilidade, pois além da alta eficácia dos corantes em diferentes proporções de células vivas e mortas, são corantes de rápida resposta e possíveis de serem analisados em diversos equipamentos, o que torna mais barato e viável a sua utilização no biomonitoramento.

Uma vantagem do uso de corantes não fluorescentes é a possibilidade de classificar os organismos, já que tanto no microscópio, como na filmagem e na FlowCAM, é necessário visualizar toda a célula, diferentemente dos fluorescentes que basta apenas o sinal da fluorescência para confirmar a viabilidade. A classificação a nível específico dos organismos é de extrema importância para o monitoramento da invasão de espécies não nativas.

Os corantes fluorescentes também tem grande potencial de uso, apesar de necessitar mais estudos quantitativos de diferentes proporções de células vivas e mortas. Além disso, para obter resultados mais acurados é mais indicado o uso de citômetro de fluxo do que o microscópio de epifluorescência.

No entanto, como cada espécie responde de forma diferente aos corantes, um protocolo mais robusto envolveria o uso de mais de uma técnica para confirmação da porcentagem de células viáveis em uma amostra. Como não foi possível a combinação do vermelho neutro com o azul de Evans, sugere-se o uso deles individualmente em diferentes etapas. Outra maneira seria estudar o uso associado a um corante fluorescente, mas também em etapas separadas, pois até o momento não há um método eficaz para contar simultaneamente células fluorescentes e não fluorescentes, a menos que use a autofluorescência juntamente com um corante mortal, como já fizeram alguns autores (Sato et al., 2004).

Não foi o objetivo deste trabalho analisar a eficiência dos tratamentos da água de lastro, mas sim a validação destes tratamentos através da coloração. Neste caso, o azul de Evans foi o mais indicado para validar o tratamento com ozônio, enquanto que para o UV o vermelho neutro teve melhores resultados. $\mathrm{O}$ germicida Peraclean não permite o uso de corantes devido ao seu efeito descolorante.

O presente estudo, de modo geral, proporcionou um maior entendimento das técnicas de coloração com diferentes espécies de fitoplâncton, explorou 
quantitativamente a eficácia deles em diversas condições de mortalidade e analisou técnicas alternativas para observação e registro das células, sendo que a captura de imagens pela filmagem teve um destaque como método substituto da contagem instantânea e morosa da microscopia. Estas informações podem contribuir para a futura aplicação no monitoramento ambiental. 


\section{Referências}

AGUSTÍ, S. \& SÁNCHEZ, M. C. 2002. Cell viability in natural phytoplankton communities quantified by a membrane permeability probe. Limnology and Oceanography 47 (3): 818-828.

ÁLVAREZ, E.; LOPEZ-URRUTIA, A.; NOGUEIRA, E. \& FRAGA, S. 2011. How to effectively sample the plankton size spectrum? A case study using FlowCAM. Journal of Plankton Research 33: 1119-1133.

BICKEL S.L.; HAMMOND, J.D.M. \& TANG K.W. 2011. Boat-generated turbulence as a potential source of mortality among copepods. Journal of Experimental Marine Biology and Ecology 401: 105-109.

BINET, M.T. \& STAUBER, J.L. 2006. Rapid flow cytometric method for the assessment of toxic dinoflagellate cyst viability. Marine Environmental Research 62: 247-260.

BRATOSIN,D.; MITROFAN, L.;PALII, C.; ESTAQUIER, J. \& MONTREUIL, J. 2005. Novel Fluorescence Assay Using Calcein-AM for the Determination of Human Erythrocyte Viability and Aging. Cytometry Part A 66A:7884.

BRUSSAARD,C.P.D.; MARIE, D ; THYRHAUG,R.;. \& BRATBAK, G. 2001. Flow cytometric analysis of phytoplankton viability following viral infection. Aquatic Microbial Ecology 26: 157-166.

BUTRÓN, A.; ORIVE, E. \& MADARIAGA, I. 2011. Potential risk of harmful algae transport by ballast waters: The case of Bilbao Harbour. Marine Pollution Bulletin 62: $747-757$.

CAMEL, V. \& BERMOND, A. 1998. The use of ozone and associated oxidation processes in drinking water treatment. Water Research 32 (11): 3208-3222. 
CARLTON, J. T. 1985. Transoceanic and interoceanic dispersal of coastal marine organisms: the biology of ballast water. Oceanography and Marine Biology An Annual Review 23: 313 - 371.

CARNEY, K. J. 2011. Marine bioinvasion prevention: understanding ballast water transportation conditions and the development of effective treatment systems. A thesis submitted for the award of Doctor of Philosophy $(\mathrm{PhD})$ at Newcastle University.

CHITARRA, L.G., BREEUWER, P., ABEE, T. \& BULK, R.W. 2006. The use of fluorescent probes to assess viability of the plant pathogenic bacterium Clavibacter michiganensis subsp. michiganensis by flow cytometry. Fitopatologia Brasileira 31:349-356.

CODER, D. M. 1997. Assessment of Cell Viability. Current Protocols in Cytometry p. 9.2.1-9.2.14

CRIPPEN, R.W. \& PERRIER, J.L. 1974. The use of neutral red and Evans blue for live-dead determinations of marine plankton (with comments on the use of rotenone for inhibition of grazing). Stain Technology 49: 97-104.

DRESSEL, D.M; HEINLE, D.R. \& GROTE, M. 1972. Vital staining to sort dead and live copepods. Chesapeake Science 13: 156-159

DUBROVSKY， J. G.; GUTTENBERGER， M.; SARALEGUI， A.; NAPSUCIALY-MENDIVIL, S.; VOIGT, B.; BALUSKA, F. \& MENZEL, D. 2006. Neutral red as a probe for confocal laser scanning microscopy studies of plant roots. Annals of Botany 97: 1127-1138.

DUHAMEL, S. \& JACQUET, S. 2006. Flow cytometric analysis of bacteriaand virus-like particles in lake sediments. Journal of Microbiological Methods 64: 316332. 
ELliOTT, D. T. \& TANG, K. W. 2009. Simple staining method for differentiating live and dead marine zooplankton in field samples. Limnology and Oceanography: Methods 7: 585-594.

FALKOWSKI, P. 2012.Ocean Science: The power of plankton. Nature 483: 1720.

FIRST, M. R. \& DRAKE, L. A. 2013. Approaches for determining the effects of UV radiation on microorganisms in ballast water. Management of Biological Invasions 4 (2): 87-99.

FUCHS, R. \& DE WILDE, I. 2004. PERACLEAN Ocean: a potentially environmentally friendly and effective treatment option for ballast water. In: Matheickal, J. T.; Raaymakers, S. (Eds.), Second International Symposium on Ballast Water Treatment. International Maritime Organization, London, pp. 175-180.

GARVEY, M.; MORICEAU, B. \& PASSOW, U. 2007. Applicability of the FDA assay to determine the viability of marine phytoplankton under different environmental conditions. Marine Ecology Progress Series 352: 17-26.

GAVAND, M.R.; MCCLINTOCK, J.B.; AMSLER, C.D.; PETERS, R.W. \& ANGUS, R.A. 2007. Effects of sonication and advanced chemical oxidants on the unicellular green alga Dunaliella tertiolecta and cysts, larvae and adults of the brine shrimp Artemia salina: A prospective treatment to eradicate invasive organisms from ballast water. Marine Pollution Bulletin 54: 1777-1788.

GGPAF, 2002-2003. AGÊNCIA NACIONAL DE VIGILÂNCIA SANITÁRIA. Brasil - Água de lastro. Projetos.

GONZÁLEZ, J.; FIGUEIRAS, F. G.; ARANGUREN-GASSIS, M.; CRESPO, B. G.; FERNÁNDEZ, E.; MORÁN, X. A. G. \& NIETO-CID, M. 2009. Effect of a simulated oil spill on natural assemblages of marine phytoplankton enclosed in microcosms. Estuarine, Coastal and Shelf Science, 83(3): 265-276. 
GOVENDER, T.; RAMANNA, I. \& RAWAT, F. B. 2012. BODIPY staining, an alternative to the Nile Red fluorescence method for the evaluation of intracellular lipids in microalgae. Bioresource Technology 114: 507 - 511.

GREGG, M.D. \& HALLEGRAEFF, G. M. 2007. Efficacy of three commercially available ballast water biocides against vegetative microalgae, dinoflagellate cysts and bacteria. Harmful Algae 6: 567-584.

GREGG, M.; RIGBY, G. \& HALLEGRAEFF, G. M. 2009. Review of two decades of progress in the development of management options for reducing or eradicating phytoplankton, zooplankton and bacteria in ship's ballast water. Aquatic Invasions 4: 521-565.

GUILLARD, R. R. L. 1975. Culture of phytoplankton for feeding marine invertebrates. In: Smith, W. L. \& Chanley, M. H. (Eds.) Culture of Marine Invertebrates Animals. New York: Plenum Publishing. p. 29-60.

HALLEGRAEFF, G. M. 1998. Transport of toxic dinoflagellates via ship's ballast water: bioeconomic risk assessment and efficacy of possible ballast water management strategies. Marine Ecology Progress Series 168: 297-309.

HERNLEM, B. \& HUA, S. 2010. Dual fluorochrome flow cytometric assessment of yeast viability. 2010. Current Microbiology 61: 57-63.

HERWIG， R. P.; CORDELl, J. P.; PERRINS, J. C.; DINNEL， P. A.; GENSEMER, R. W.; STUBBLEFIELD, W. A.; RUIZ, G. M.; KOPP, J. A.; HOUSE, M. L. \& COOPER, W. J. 2006. Ozone treatment of ballast water on the oil tanker $S / T$ Tonsina: chemistry, biology and toxicity. Marine Ecology Progress Series 324: 37-55.

HIJEN, W. A. M.; BEERENDONK, E. F. \& MEDEMA, G. J. 2006. Inactivation credit of UV radiation for viruses, bacteria and protozoan (oo)cyst in water: a review. Water Research 40: 3-22. 
HOBBIE, J.E.; DALEY, R.J. \& JASPER, S. 1977. Use of Nuclepore filters for counting bacteria by fluorescence microscopy. Applied and Environmental Microbiology 33: 1224-1228.

HOIGNE, J. 1998. Chemistry of Aqueous Ozone and Transformation of Pollutants by Ozonation and Advanced Oxidation Processes. Edited by J. Hrubec. The Handbook of Environmental Chemistry, Vol. 5 Part C, Quality and Treatment of Drinking Water Springver-Verlag, Berlin.

HÜLSMANN, N. \& GALIL, B. S. 2001. The effects of fresh water flushing on marine heterotrophic protists: implications for ballast water management. Marine Pollution Bulletin 42: 1082-1086.

IDE, K.; TAKAHASHI, K.; KUWATA, A.; NAKAMACHI, M. \& SAITO, H. 2008.A rapid analysis of copepod feeding using FlowCAM. Journal of Plankton Research 30 (3): 275 - 281.

IMO. International Maritime Organization. 1998. Harmful Aquatic Organisms in Ballast Water: Report of the Working Group on Ballast Water Convened during MEPC 41. MEPC 42/8.

IMO. International Maritime Organization. 2004. Convention BWM/CONF/36 Adopted 13 February 2004. "International Convention for the Control and Management of Ships" Ballast Water and Sediments.

JONES, K. H. \& SENFT, J. A. 1985. An improved method to determine cell viability by simultaneous staining with fluorescein diacetate-propidium iodide. The Journal of Histochemistry and Cytochemistry 33: 77-79.

KAWACHI, M \& NOËL, M. 2005. Sterilization and sterile technique. In: Andersen, R. A. (Ed.) Algal Culturing Techniques. London: Elsevier Academic Press. p. $65-81$. 
KNAP, A.; DEWAILLY, É.; FURGAL，C.; GALVIN, J.; BADEN，D.; BOWEN, R. E.; DEPLEDGE, M.; DUGUAY, L.; FLEMING, L. E. \& FORD, T. 2002. Indicators of ocean health and human health: developing a research and monitoring framework. Environmental Health Perspectives, 110 (9): 839.

LAFONTAINE, Y.; DESPATIE, S. \& WILEY, C. 2008. Effectiveness and potential toxicological impact of the PERACLEAN@ Ocean ballast water treatment technology. Ecotoxicology and Environmental Safety 71: 355-369.

LIEBICH, V.; STEHOUWER, P. P. \& VELDHUIS, M. 2012. Re-growth of potential invasive phytoplankton following UV-based ballast water treatment. Aquatic Invasions 7 (1): 29-36.

LOURENÇO, S. O.; BARBARINO, E.; MANCINI-FILHO, J.; SCHINKE, K. P. \& AIDAR, E. 2002. Effects of different nitrogen sources on the growth and biochemical profile of 10 marine microalgae in batch culture: an evaluation for aquaculture. Phycologia 41 (2): 158-168.

LOURENÇO, S. O. 2006. Cultivo de microalgas marinhas - princípios e aplicações. São Carlos: Rima.

MATSUOKA, K. \& FUKYO, Y. 2000. Technical guide for modern dinoflagellate cyst study. WestPac-Hab/ WestPac/IOC, $2^{\mathrm{a}}$ ed.

ONJI, M.; SAWABE, T. \& EZURA, Y. 2000. An Evaluation of Viable Staining Dyes Suitable for Marine Phytoplankton. Bulletin of the Faculty of Fisheries Hokkaido University, 51(3): 153-157.

PEPERZAK, L. \& BRUSSAARD, C. P. D. 2011. Flow cytometric applicability of fluorescent vitality probes on phytoplankton. Journal of Phycology 47: 692-702. 
PIMENTEL, D.; LACH, L.; ZUNINGA, R. \& MORRISON, D. 2000. Environmental and economic costs of nonindigenous species in the United States. BioScience 50: 53-65.

Reavie, E. D.; Cangelos, A. A.; \& Allinger, L. E. 2010. Assessing ballast water treatments: Evaluation of viability methods for ambient freshwater microplankton assemblages. Journal of Great Lakes Research 36: 540-547.

REYNOLDS, A.E.; MACKIERNAN, G.B. \& VAN VALKENBURG, S.D. 1978. Vital and mortal staining of algae in the presence of chlorine-produced oxidants. Estuaries 1: 192-196.

RUIZ, G. M.; RAWlingS, T. K.; DOBBS, F. C.; DRAKE, L. A.; MULLADY, T.; HUQ, A. \& COLWELL, R. R. 2000. Global spread of microorganisms by ships. Nature 408: 49-50.

SARIA, A. \& LUNDBERG, J. M. 1983. Evans blue fluorescence: quantitative and morphological evaluation of vascular permeability in animal tissues. Journal of Neuroscience Methods. 8(1): 41-9.

SATO, M.; MURATA, Y.; MIZUSAWA, M.; IWAHASHI, H. \& OKA, S. 2004. A Simple and Rapid Dual-fluorescence Viability Assay for Microalgae. Microbiol. Cult. Coll. 20 (2): 53 - 59.

SIERACKI, C. K.; SIERACKI, M. E. \& YENTSCH, C. S. 1998. An imagingin-flow system for automated analysis of marine microplankton. Marine Ecology Progress Series 168: 285-296.

SILVA, J. S. V. \& SOUZA, R. S. C. L. 2004. Água de lastro e bioinvasão. Rio de Janeiro: Interciência.

SILVA, N. J. 2012. Influência de dinoflagelados potencialmente nocivos sobre o zooplâncton de uma região costeira subtropical: uma abordagem experimental. 
Dissertação apresentada ao Instituto Oceanográfico da Universidade de São Paulo, Programa de Oceanografia, área de Oceanografia Biológica, São Paulo.

STEHOUWER, P. P.; FUHR, F. \& VELDHUIS, M. J. W. 2009. A novel approach to determine ballast water vitality and viability after treatment. Emerging Ballast Water Management Systems. GloBallast, IMO, Malmö, Sweden, pp 233-240.

STEHOUWER, P. P.; LIEBICH, V. \& PEPERZAK, L. 2013. Flow cytometry, microscopy, and DNA analysis as complementary phytoplankton screening methods in ballast water treatment studies. Journal of Applied Phycology 25: 1047-1053.

STEINBERG, M.K.; LEMIEUX, E. J. \& DRAKE, L. A. 2011. Determining the viability of marine protists using a combination of vital, fluorescent stains. Marine Biology 158: 1431-1437.

SUMMERFELT, S.T. 2003. Ozonation and UV irradiation/an introduction and examples of current applications. Aquacultural Engineering 28: 21-36.

SUTHERLAND, T.F.; LEVINGS, C.D.; PETERSEN, S. \& HESSE, W.W.2003. Mortality of zooplankton and invertebrate larvae exposed to cyclonic pretreatment and ultraviolet radiation. Marine Technology Society Journal 37: 3-12.

TANG K.W.; DZIALLAS C. \& GROSSART H-P. 2011. Zooplankton and aggregates as refuge for aquatic bacteria: Protection from UV, heat and ozone stresses used for water treatment. Environmental Microbiology 13: 378-390.

Thyssen, M.; Mathieu, D.; Garcia, N. \& Denis, M. 2008. "Short-term variation of phytoplankton assemblages in Mediterranean coastal waters recorded with an automated submerged flow cytometer." Journal of Plankton Research, vol. 30, no. 9, pp. 1027-1040.

USEPA. United States Environmental Protection Agency. 2011. Ballast water self monitoring. Ballast water discharges from vessels. 
VELDHUIS, M. J. W.; KRAAY. G. W. \& TIMMERMANS, K. R. 2001. Cell death in phytoplankton: correlation between changes in membrane permeability, photosynthetic activity, pigmentation and growth. European Journal of Phycology 36: 167-177.

WAITE, T.D.; KAZUMI, J.; LANE, P.V.Z.; FARMER, L.L.; SMITH, S.G.; SMITH, S.L.; HITCHCOCK, G. \& CAPO, T.R. 2003. Removal of natural populations of marine plankton by a large scale ballast water treatment system. Marine Ecology Progress Series 258: 51-63.

WRIGHT, D.A.; GENSEMER, R.W.; MITCHELMORE， C.L.; STUBBLEFIELD, W. A.; GENDEREN,E.; DAWSON, R.; ORANO-DAWSON,C.E.; BEARR, J. S.; MUELLER, R. A.; \& COOPER, W. J. 2010. Shipboard trials of an ozone-based ballast water treatment system. Marine Pollution Bulletin 60: 1571-1583

ZETSCHE, E. \& MEYSMAN, F. J. R. 2012. Dead or alive? Viability assessment of micro- and mesoplankton. Journal of Plankton Research 34 (6): 493-509.

ZVYAGINTSEV, A. Y.; IVIN, V. V.; KASHIN, I. A.; ORLOVA, T. Y.; SELINA, M. S.; KASYAN, V. V.; KORN, O. M.; KORNIENKO, E. S.; KULIKOVA, V. A.; BEZVERBNAYA, I. P.; ZVEREVA, L. V.; RADASHEVSKY, V. I.; BELOGUROVA, L. S.; BEGUN, A. A. \& GORODKOV, A. N. 2009. Acclimation and Introduction of Hydrobionts Ships' Ballast Water Organisms in the Port of Vladivostok. Russian Journal of Marine Biology 35: 41-52. 